\title{
SISTEMAS DE PLANTIO DIRETO E CONVENCIONAL UM ENFOQUE DE ANÁLISE DE DECISÃO
}

CARLA CASTRO SALOMÃo

Engenheiro Agrónomo

Orientador: Prof. Dr. Jose Ferreira de Noronha

Dissertação apresentada a Escola Superior de Agricultura "Luiz de Queiroz", da Universidade de São Paulo, para obtenção do título de Mestre em Agronomia, Area de Concentração: Economia Agrária.

$P I R A C I C A B A$

Estado de São Paulo - Brasil

Setembro - 1990 
Ficha catalográfica preparada pela Seça de livros da Divisão de Biblioteca e Documentação - PCAP/USP

Salomão, Carla Castro

S173s Sistemas de plantio direto e convencional; um enfoque de análise de decisão. Piracicaba, 1990. $127 \mathrm{p}$.

Diss. (Mestre) - ESALQ

Bibliografia.

1. Plantio direto - Análise de decisão 2. Plan tio direto - Desempenho 3. Plantio direto - Produ tividade I. Escola Superior de Agricultura Luiz de Queiroz, Piracicaba

CDD 338.16 


\title{
SISTEMAS DE PLANTIO DIRETO E CONVENCIONAL UM ENFOQUE DE ANALISE DE DECISÃO
}

\author{
Carla Castro Salomão
}

Aprovado em: $11,10,90$

\section{Comissão Julgadora:}

Prof. Dr. Jose Ferreira de Noronha

Pror. Dr. Fernando Curi Peres

Prof. Dr. Antonio Luiz Fancelli
ESALQ USP

ESALO USP

ESALQ USP

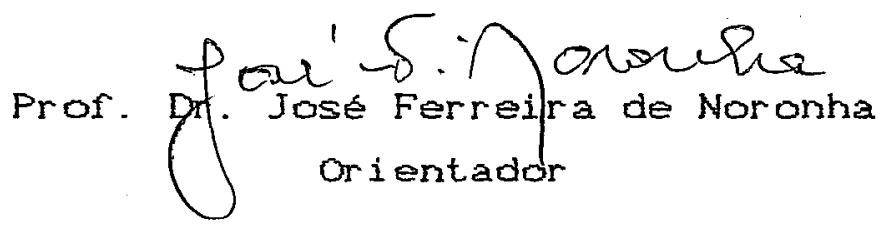




\section{Dedico}

A minha insubstituível e eterna amiga e mãe, cuja memória e amor foram o incentivo que me permitiu chegar ao termino deste trabalho.

\section{of ereco}

Ao meu querido aviador e pai, pelo exemplo constante de dedicação e capacidade profissional.

Ao meu irmão, pelas lições de juventude e pureza de coraçฐ̃o.

Ao meu companheiro e amigo de todas as horas, Manuel. 


\section{AGRADECIMENTOS}

A todos que contribuíram de alguma forma na execução deste trabalho, em especial as seguintes pessoas e institui çes:

ESALQ - Prof. Dr. Jose Ferreira de Noronha, amigo e orienta dor, Prof. Dr. Fernando Peres, pelas valiosas criticas na parte metodologica. Prof. Dr. Carlos Bacha, pela criteriosa revisão. Funcionários da Biblioteca do Dep to de Economia $e$ Sociologia Rual da USP, pela ajuda na pesquisa bibliografica. Ciagri, por toḍo o apoio na aréa de informática, em especial à figura do engenheiro Nermano Franco Ferreira, cujo trabalho e paciencia viabilizaram o processamento dos dados.

- Iapar - ao Sr. Presidente Marcus Vieira, que abriu as por tas da instituição para que se pudesse realizar o estudo. cedendo informaçóes e apoio valiosos; ao Dr. Ruy Yamaoka, pela organização e fornecimento dos dados.

- Empraba - ao Dr. Derci Dosse, pelo incentivo e auxilio. na fase inicial da pesquisa.

- FEALQfFINEP, dentro do projeto Avaliaçäo de Novas Tecnoiogias.

- ICI Brasil SA - na obtenç̃o de alguns dados e fornecimento de informaçoses tecnicas.

Em especial, gostaria de agradecer ao apoio e carinho da familia do Dr. Valter Guimarães, pela atenção paternal e carinhosa acolhida durante os meses de trabalho em Londrina.

Ao querido amigo Renato Guerrini, pelo cuida doso trabalho de organização do texto e digitação de partes deste trabalho, bem com a sua familia, pelas diversas acolhidas em Piracicaba.

Ao meu namorado Manuel, pelo apoio incansável nas diversas fases deste trabalho, auxiliando a superar os inúmeros obstáculos encontrados. 


\section{SUMARIO}

Página

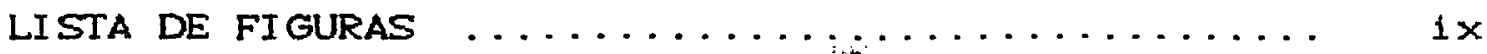

LISTA DE TABELAS $\ldots \ldots \ldots \ldots \ldots \ldots \ldots \ldots \ldots \ldots \ldots \ldots$

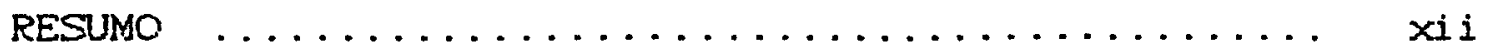

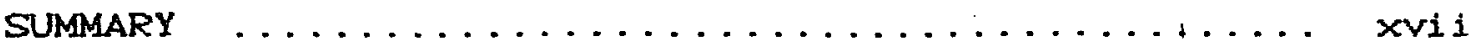

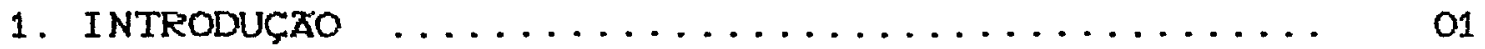

1.1. Consideraçōes iniciais .............. o1

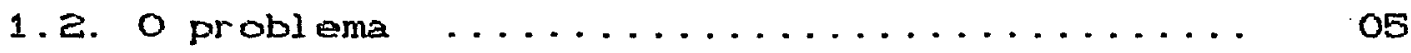

1.3. o Plantio Direto no Paraná ............ o7

1.4. Objetivos $\ldots \ldots \ldots \ldots \ldots \ldots \ldots \ldots \ldots \ldots$

1.4.1. Objetivo principal ............ 12

1.4.2. Objetivos especificos $\ldots \ldots \ldots \ldots 13$

2. ASPECTOS TECNICOS DOS SISTEMAS DE PLANTIO ..... 14

2.1. Perdas de solo e água ................ 14

2. 2. O papel da cobertura vegetal ........... 3e

2.2.1. Agua e temperatura ........... 32

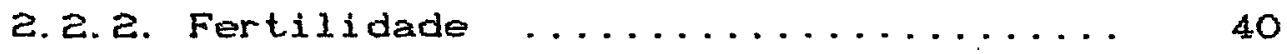

2.2.3. Controle de ervas ............. 44

2.2. 4. Produtividade .............. 47

3. MATERT AL E METODOS .................... 53

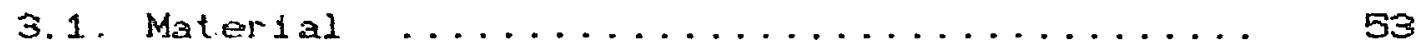

3.1.1. Caracteristicas do ensaio ........ 54

3. 2. Metodas ....................... 61 
3.2.1. Msdia-Variancia (Tobin-Markowits).... 64

3.2.2. Criterio de Simetria (Hanoch-Levy)... 72

3.2.3. Domináncia Estocástica (Quirk-Saposnik) 74

4. RESULTADOS E DISCUSSAO .................. 81

4.1. Compar ação entre Plantio Direto e Convencional .......................... 81

4.1.1. Aspectos F1sicos .............. 81

4.1.1.1. Por rotação ........... 8z

4.1.1.2. Por cultura ........... 83

4.1.1.2.1. Milho....... 83

4.1.1.2. 2. Soja ....... 85

4.1.1.2.3. Trigo ....... 89

4.1.2. Aspectos Economicos ............. ge

4.1.2.1. Lucros ............... ge

4.1.2. 2. Custos .............. 94

4.2. Escolha das alternativas .............. 99

4.2.1. Seleção pela Média-Variancia ....... 99

4.2.2. Seleção pela Dominância Estocástica. . 101

5. CONCLUSOES E SUGESTOES .................... 104

5.1. Limitações do estudo ................ 10 I

5. 2. Sugestzes para proximos trabalhos ....... 108

6. REFERENCI AS BI BLI OGRAFI CAS ............. 108

7. APENDICES ......................... 116

7.1. Apêndice 1 - Produtividade do milho por sistema de cultivo e rotação. Londrina $1976 / 1988$ (media de 3 repetiçzes) 
7.2. Apéndice 2 - Produt1 vidade da soja por sistema de cultivo e rotaçăo. Londrina $1976 / 1988$ Cmédia de 3 repetiçช̃es?

7.3. Apendice 3 - Produtividade do trigo por sistema de cultivo e rotação, Londrina $1976 / 1988$ (medi a de 3 repetiçós

7.4. Apéndice 4-Lucros por sistema de plantio e rotação ................

7.5. Apéndice 5 - Gastos nas operaçB̃s, por rotaf̧a. em plantio direto e conven-

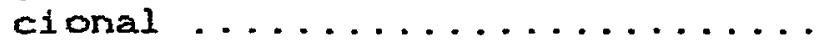

7.6. Apendice 6 - Diferença percentual de gastos - ganho percentual (Pd-PC), por atividade e rotaçăo, entre os sistemas de plantio - 1976/1977 a

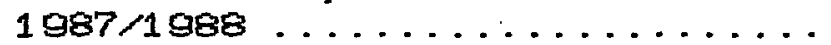

7.7. Apéndice 7 - Diferença de gastos em OTNMa e ganho, por atıvidade e rotação. entre os sistemas (Pd-PC). $1976 / 1977$ a $1987 / 1988 \ldots \ldots \ldots \ldots$. 


\section{LISTA DE FIGURAS}

Página

FIGURA 1 - Precipitaḉ̧es $(\mathrm{mm}$ média anual e máxima (24 h) na area do ensaio. julho 1976 a ju 1ho $1988 \ldots \ldots \ldots \ldots \ldots \ldots . . \ldots \ldots$

FIRURA 2 - Precipitaç̧̋es $(\mathrm{mm}$ média anual e máxima (24 hj na área do ensaio. julho 1976 a

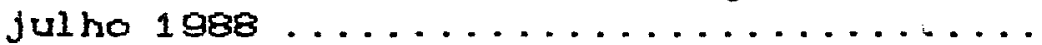

FIGURA 3 - Curvas de utilidade [UCRD] conforme a pro pensão ao risco; a) aversos; b3 indiferetes e cl propensos .................

FIGURA 4 - Distribuiçס̃es de probabilidades de retornos 12 assimetrica a esquerda e 2 assimetrica a direita, para 2 casos hipo-

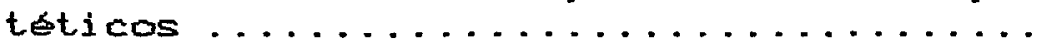

FI GURA 5 - FunçB̂s densidade de retorno de 5 al terna tivas arriscadas, para o a) PGD; bJ SGD c) $\mathrm{TGD} \ldots \ldots \ldots \ldots \ldots \ldots \ldots \ldots$

FI GURA $G$ - MEdia do l ucro [EC $\infty]$ em função da varian cia $[V(X)$ ] para 6 alternativas $[A C, B C$, $D C, A D, B D$ e $D D D$ e frontelra eficlente

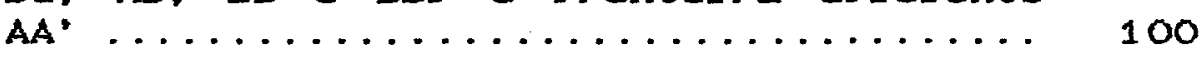

FIGURA 7 - Curvas das funçöes cumulativas de probabllidade das $B$ alternativas $C A C, B C$. $D C, A D, B D$ $\in D D D \ldots \ldots \ldots \ldots \ldots$ 


\section{LISTA DE TABELAS}

Página

TABELA 1 - Evol ução da área (ha) sob plantio direto no Brasil e Paraná. Particlpação e indice de variaçăo $C \%$ da área no Paraná...

TABELA 2 - Redução da espessura do horizonte A e perdas de solo em sistemas de plantio convencional e direto, em rotaçóses de diversas culturas. LRd, $6 \%$ de declive...

24

TABELA 3 - Influéncia de sistemas de preparo do solo nas perdas por erosão, com chuva simul ada. LRd - 1976/1977 ..........

TABELA 4 - Produção do trigo $\mathrm{kg} / \mathrm{ha}$ em P.c. e P.d. para o grão com $14 \%$ de umidade. Londrina, $1978 / 1980 \ldots . . \ldots \ldots \ldots . . .$.

TABELA 5 - Precipitação $(\mathrm{mm})$ media e máxima (Z4 h), mensal e anual em Londrina, de julhor 76

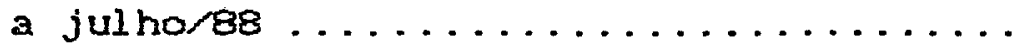

TABELA 6 - Análise química do solo. de amostras coletadas na camada arável $(0-20 \mathrm{~cm}$ por ocasião da escolha da area do ensaio CLRd) ........................

58

TABELA 7 - Sucessão de cul turas de verão utilizadas

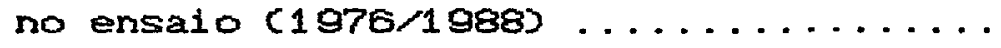

59

TABELA 8 - Espaçamento e demsidade de semeadura uti lizados no experimento. Londrina, safras $1976 / 1977$ a $1987 / 1988 \ldots \ldots \ldots \ldots \ldots \ldots . .$.

60

TABELA 9 - Receita bruta COTN/has e variação percen tual entre os sistemas $(D / C)$, por periodo e total, conforme a rotação $1976 / 1977$ a $1987 / 1988 \ldots \ldots \ldots \ldots \ldots$

TABELA 10 - Variação percentual entre os periodos, nas produtividades do milho, por rotacão e sistema de plantio - 1976/1977 a

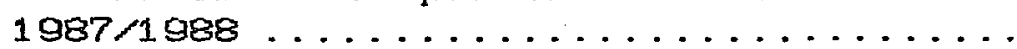


TABELA 11 - Variação percentual nas produtividades da soja, por rotação e sistema de plantio, entre os periodos .............

TABELA 12 - Vantagens relativas $6 \%$ das produtivida des de trigo entre as rotaçies e os sistemas de plantio .................

TABELA 13 - Variação percentual nas produtividades do trigo, por rotação e sistema de plantio, entre os periodos ..............

TABELA 14 - Lucros COTNMa) e indices comparativos entre os sistemas de plantio CDir/ Conv. ). por rotação. $1976 / 1977$ a $1987,1988 \ldots \ldots \ldots \ldots \ldots \ldots . . . \ldots \ldots$

TABELA 15 - Custo medio COTN/has e percentual de diferença de custos CD/CS entre os sistemas de plantio - 1976/1988 .........

TABELA 16 - Participação dos custos $c \%$ nas atividâ des, por rotação e sistema de plantio 1976,1977 a $1987 / 1988 \ldots \ldots \ldots \ldots \ldots . . .$. 


\section{RESUMO}

- fato de se ter pouca informação ou experiéncia sobre determinada prática, dificulta sua utilização por parte dos agricultores, que não conseguem enxergar as mesmas vantagens comparativas reconhecidas pelos ténicos. o risco, ao qual a atividade agrícola está fortemente exposta, se encontra diretamente envolvido neste processo. Seria desejável que pacotes tecnológicos novos estivessem baseados em modelos económicos que levem este aspecto em consideraçăo, enriquecendo a análise e permitindo o melhor entrosamento da pesquisa com as necessidades do agricultor. O sistema de plantio direto. sendo uma técnica bastante revolucionária, ilustra bem este problema. pois exige grandes mudanças na organização do trabalho e do emprego dos f́atores de produção, na propriedade agrícola. E preciso que o responsavel pelas decisóes esteja ciente e disposto a se adaptar a nova realidade. Consiste basicamen te na semeadura sobre os restos da cultura anterior, com 
movimentaça do solo apenas no sulco onde sáo depositadas as sementes. O restante da área permanece com o solo protegido pelos restos vegetais, dessecados pelos herbicidas de préplantio.

Com o objetivo de comparar o desemperho, medido pelos lucros e riscos, do plantio direto com o convencional $C 1$ araçăo e $e$ gradagens), wiilizou-se um ensaio de longa duração (12 anos do Instituto Agronómico do Paramá Iapar, que está sendo desenvolvido na estação experimental de Londrina. Foram escolhidas as rotaços A Csoja $x$ trigo), $B$ (milho $x$ trigo) $e D$ csoja $x$ trigo $x$ milho), submetidas aos dois sistemas de plantio, por serem as mais. comurs na região do experimento.

Como instrumento de anklise, utilizou-se os motodos de média-variancia e dominánela estocástica, da Teo ria da Decisão. Os principais riscos da atividade agricola Colima e mercadoj estiveram representados na equação de lucro (receita-custo), atraves das informaçoses de preços mensais e da produtividade de cada safra.

Os resultados mostram que a melhor alternativa roi a rotaçăo das 3 culturas sob plantio direto. Esta escolha foi comum a ambos os criterios de seleça. Isto mostra que a dominância estocastica de $e^{0}$ grau foi 
equi valente à média-variancia (ANDERSON et aliz, 1977). 0 poder de discriminaçáo foi de $100 \%$ nos dols criterios; pois apenas uma alternativa foi indicada, entre as 6 apresentadas.

As maiores produtividades da soja, milho e trigo, foram obtidas com o plantio direto, em ríveis que va riam conforme a rotaçăo adotada, com melhor desempenho da rotação D. A rotação soja $x$ trigo CAj trouxe prejuizos nos dois sistemas de plantio, com perdas de 70,83 OTN/ra a mais no plantio direto. Nas demais, as vantagens do plantio direto corresponderam a 29.35 OTNha e 49,17 OTN/ha. respectivamente nas rotaçōes $B \in D$.

os principais componentes do custo para o Plantio convencional foram, em ordem decrescente de valor. - uso da terra (AL), a adubaç̃o (AD), a semeadura CSE $e$ o controle de plantas daninhas (PD), sendo este úlimo, $e^{\circ}$ na escala do plantio direto, com o dobro de sua participação em relação ao plantio convencional, significando de 85\% a $169 \%$ a mais de disperndio.

O plantio direto mostrou desempenho superior em anos climaticamente desfavoraveis isecass, para as produ tividades das tres culturas, sob qualquer rotaçăo.

De modo geral, as produtividades caíram no 
último periodo do estudo (1984/1988). tanto para o plantio direto quanto para o convencional. Talvez 1 sto possa ser explicado pela queda na capacidade produtiva do solo, no plantio convencional, e o seu nocivo adensamento, no plantio direto. Estes resultados refletem as condiçoses especificas do estudo em questão, al fom do que, por'tratar-se de um ensaio experimental, revestem-se de caracteristicas distintas das encontradas numa situação de produção comercial. For outro lado, a obtença de informaçbes seguras, ao longo de varios amos, e a consideração dos riscos de mercado clima, garantem o nivel de confiabilidade, permitindo maior riqueza na análise dos resultados apjesentados.

A estrutura de prefos e o comportamento das produtividades no horizonte do estudo mostraram que o siste ma de plantio direto requer o acompanhamento técnico cuidadoso para ser bem sucedido, atraves de providéncias tomadas antes e durante a sua implementação e uso.

A escolha da sucessão de culturas foi de grande importancia pois, tarto o melfor quanto o pior resul tado alcancado, foram sob o mesmo sistema de plantio (direto), diferindo aperas na rotaço $(D$ ou $A$.

Outros estudos são necessários para maiores insormaçós sobre o plantio direto, com énfase no comporta- 
mento das produtividades sob as diferentes condiçóes de so10. clima e rotaçóes de culturas praticadas, a utilizaçăo de herbicidas e manejo no controle de ervas e economia dos recursos aplicados Csolo, capital, tempo, mão-de-obra etc. J.

Seria interessante a comparação entre os sis temas de plantio, a mivel de propriedade agricola. A dificuldade para isto se encontra na obtença de dados confiaveis, que cubram um horizonte de anos razóvel, para maior sequrança na recomendaço dos resultados al cancados. 
xisi

\section{SUMMARY}

The lack of farmer information or experierce restrain him from seing the same advantages proclamed by the researchers about some new techniques. This process is straightly related to a different sort of risk, that should be considered in all economic analysis providing results that could better fit the needs of the producers.

No-till is a revolutionary planting system and a good illusiration for the exposed process. It involves a completiy different allocation of resources and administration of work. The decision makers must have this in mind if they want to deal with this new technique. It consists on no seed bed preparation except that done by the planter. The growing weeds and residues of former crop are controled by herbicides and keep protecting the soil from raindrops, sur and wind.

Data from a twelve year fielo experiment in the Agronomic Institute of Parana - Iapar, were used to 
compare risks and long run profit of no-till to conventional tillage.

Among the crop succession submitted to both planting systems, three were chosen because of their frequent use in the region. These are soybean $X$ wheat $(A)$, $\operatorname{cor} \mathrm{x}$ wheat (B) and soybear $\mathrm{X}$ wheat $\mathrm{x}$ corn $\mathrm{CD}$.

This study dealt with two criteria of evaluation for decision under uncertainty: E-V Analysis and Stochastic Dominance.

Environmental and market-related risks are present in the profit equation (income-cost) through anual productivity and monthly prices of inputs.

The results pointed out rotation D Csoybean $x$ wheat $x$ corn under notill system as the best al ternative, despite of the method utilized in evaluating risk. This shows verify the equivalence of these two mathematic instrumental (ANDERSON et aliz, 1977). Only one alternative was recommended among the six available, showing an discriminatory power of $100 \%$

No-till offered the highest productivity for all crops, with better performance under crop rotation D. Rotation A showed negative results under both systems of production with a loss of 70.83 oTN/ha under conventional 
tillage lorger then the no-till system. For rotation $B$ the advantage of no-till was of 29,35 oTN/ha reaching 49,17 OTN/ha under rotation $D$.

The scale-up for the key components of costs in conventional cropping are land use CAL3, fertilization (AD), seedling $C S E$ ) and weed control (PD). The no-till scale is identical with weed control ir second place with double weight, meaning $85 \%$ to $169 \%$ more of expenditure.

No-till showed superior performance in hard weather conditions for all crops and rotations.

In general, productivities fell down in the last period (1984/1988) in no-till and conventional tillage. This may be hapening due to the soil distressing under conventional tillage and the harmful soil compactation on no-till system. This reflects the particular conditions of this study, unlike the ones we found in a commercial production site. On the other hand, safety informations all over this long period and the consideration of the prineipal agricultural risks enriches the analysis and brings it close to the producers needs.

Price structure and productivity behavior along the foccused period prooved that the no-tillage copping system requires management skills and technical 
assistance to be successful.

Both, the best (crop rotation D) and the worsi (crop rotation A) results were found under no-till system, showing the importance of a proper choice of a sequence of crops.

Other studies are necessary for broader information about no-tillage system, mainly concerning productivity under different soils and climate conditions. crop rotation influence, herbicides use and resources economy.

Data from farms actual with different tillage systems would be helpful for a worthy comparision. Problems with a long period of proper farm data Informations could turn it too hard to be found. 


\section{INTRODUCÁAO}

\subsection{Consideraçóes iniciais}

No Estado do Parana. 85\% dos solos agricultaveis ja estro sendo explorados CSORRENSON \& MONTOYA, 1984). Porém, há até bem pouco tempo ccerca de 60 anos esta realidade era muito diferente, com o Estado praticamente ocupado por uma densa floresta tropical e subtropical. Esta modificação a caminho da ocupação, teve inicio nas décadas de 30 e 40 , com a vinda de desbravadores em busca de boas terras para o café algodá

Evidentemente, o sistema ecolbgico que se encontrava em equilibrio foi drasticamente alterado. advindo a rapida e devastadora erosão. Já na decada de 50 , em algumas regióses do Paraná, surgiam as primeiras vossor ucas e e empobrecimento do solo CMONDARDO, 19773.

Recentemente, este problema foi seriamente agravado, devido a substituiçăo do zafé pelo binkmio soja $x$ trigo que, como observa TOMASINI (1977b), se intensificou a partir de 1989. Novas técnicas, visando o aumento da produtividade, estiveram associadas a este crescimento 
Cnovas máquinas, sementes melhoradas, medidas fitossanitárias, etc. , possibilitando os saltos na produtividade, e consequente produção, destas culturas, no pais.

o que se verificou, no entanto, foi que grande parte deste aumento na produção ocorreu por uma real e crescente expansão da fronteira agricola, nas bases estensivas tradicionais: Quer dizer, mais áreas eram incorporadas a atividade agricola, com tranferencia do problema de erosão do solo. Assim e que encortramos uma situação de solos improdutivos, cansados, com quedas de produti vidade.

Apesar de se registrar aumentos nas produtividades da soja, milho e, menos pronunciadamente, no trigo, o Brasil foi o pais que apresentou maior queda na produtividade dos insumos $187 \%$, entre outros 9 paises avaliados, de 1980 a 1980 (SORRENSON \& MONTOYA, 1984). Em flagrante contraste a esta realidade, neste mesmo periodo efetuaram-se os maiores investimentos no setor agricola. com utilizaçăo mais intensiva de maquinas e insumos de um modo geral crertilizartes, sementes melhoradas, defersivos, ete. $;$ a maior taxa de elevaçăo na quantidade de fertilizante aplicada, por exemplo, foi a do Brasil $6980 \%$. MENDES \& DOSSA (1981) mostram que, para um crescimento de $8,4 \%$ na produçăo agricola paranaense, de 
1970 a 1980 , o incremento correspondente na produtividade foi de apenas $0,5 \%$. Num futuro proximo, como lembra TOMASINI (1977a), Se não houver mudarças na conduta até aqui observada, grande parte dos atuais esforços governamentais oriundos da pesquisa, crédito e outros, estara invalidada por uma questão basica: a falta de capacidade produtiva dos solos, para a qual ainda räo se encontrou substitutivo (DANIEL, 1981 ).

MONDARDO (1977) identifica a questäo do empobrecimento dos solos, como sendo a possivel responsável pelo éxodo rural que se verificou no noroeste do Parana, em funçăo de uma baixa renda na agricultura, embora outros fatores possam estar contribuindo para isto. Efeitos e causas semelhantes aos até aqui descritos foram, tambem, detectados por HILL (1962) em seu trabalho sobre aspectos regionais do desenvol vimento economico ocorrido nos Estados Unidos a partir de 1914.

E preciso que se intersifique a pesquisa de novos sistemas de produça, mais apropriados as condiços climaticas, que possibilitem menores variaçóes na produção e melfor aproveitamento da capacidade produtiva dos solos. Isto $\Leftrightarrow$ extremamente importante pois, como bem observam VOGEL \& HAHN C1972), a agricultura é um setor altamente competitivo e em areas de declinio das condifres de 
produçá os agricultores vão perdendo sua capacidade para competir. Assim, necessitam de novas alternativas que os ajudem a preservar os seus recursos produtivos.

Novas tecnologias implicam numa nova forma de condução da exploração e podem requer er usos adicionais de insumos, com modificaçóes no uso dos fatores de produção. O risco tende a atuar como impedimento na adoça destas inovaços (BAREOSA, 1976). Assim, o agricultor se prende às práticas tradicionais, numa tentativa de se precaver contra a incerteza CMOUTINHO, 1977; BISERRA, 19853

DILLON (1977as lembra que a escolna da tecnologia e um problema complexo, onde não se tem certeza do retorno 11 quido por unidade, de cada tecnologia. Assim, as fontes geradoras de pesquisa, precisam estar capacitadas a dar melhores informaçbes sobre as distribuiços probabilisticas dos retornos, que resultam do uso das diferentes tecnologias.

For outro lado, os criterios económicos erou psicologicos dos agricultores, costumam diferir bastante daqueles dos tecnicos e exterisionistas. E isto que não permite que o agricultor enxergue as mesmas vartagens: preconizadas pelos técnicos, nas novas tecnologias. E neste 
ponto que a nova tecnologia se expere ao risco de ter pouca. ou nenhuma, aceitação.

A não-consider ação do risco pelos orgãos de pesquisa agropecuária, pode aumentar o hiato existente entre as informaçōes geradas e aquelas que estão sendo demandadas pelos agricultores (PACHECO, 1985). A fim de melhorar o conteúdo das informaçós passadas pela pesquisa, e fundamental que se intensifiquem os estudos de avaliaça economica que incorporem o risco.

A seguir, descrevemos a problema que identificamos e traçamos um breve histórico sobre o Plantio Direto no Estado do Farana. Logo apos, listamos os objetivos do trabalho $e$, no capitulo $a$, discorremos sobre alguns aspectos técnicos do sistema de plantio direto. No capitulo 3 apresentamos o material e os métodos utilizados na pesquisa e no seguinte, apresentamos os resultados da presente analise. Finalmente, chegamos a conclusão e sugestós para outros estudos, no capítulo 5.

\subsection{O problema}

Considerando-se as perdas significativas de solo que vinham correndo, e ainda ocorrem, no estado do Paraná, é primordial gue se passe a explorar a atividade agricula num carater menos espoliativo e mais consciente, 
de forma a manter a capacidade produtiva destes solos.

Neste contexto; o Plantio Direto surge como uma alterrativa de interesse, a fim de que esta capacidade produtiva possa ser mantida ou, até mesmo, incrementada.

A maior parte das pesquisas sobre o assunto tem procurado respostas para problemas tecnicos na adoça do novo sistema, o que e natural e necessário. A pesquisa economica, por sua vez, tem sido bastante discreta. 0 distanciamento que existe entre estes dois ramos da pesquisa, dificulta enormemente avanços nas análises económicas. Grande parte dos estudos económicos se restringe as analises de orçamentação parcial. válidas para um determinado instante no tempo, reduzindo, em muito, o conteúdo informativo das experimentações realizadas. A obtençăo de informaçós de coeficientes técricos de produção, dados climaticos e de mercado, se faz necessaria ano a ano, numa serie temporal que seja significativa, a fim de que se possa fazer uma avaliação com bases mais solidas CMOUTINHO, $1977 ;$ PACHECO, 19853.

Naturalmente, esta inovaçăo traz consigo embutidos riscos, de varias magnitudes e aspectos, que se refletem nos rendimentos alcangatos. Este é um fator decisivo na tomada de decisão do agricultor. E fundamental identifica-lo e medi-lo, a partir dos dados disporiveis. 
A crescente difusão do método, a expressiva diminuifăo nas perdas de solo e a falta de dados consistentes referentes ao novi sistema de plantio. justificam seu estudo economico. $\vec{E}$ importante que se dé este tipo de informaçăo ao agricultor, a fim de o habilitar a optar melhor, dentro de seus 1 imites de açäo.

Este trabalho pretende contribuir para a sol ução do problema de decisão do agricultor, no momento de optar pela pratica do plantio direto, versus outros sistemas de plartio. Para tanto, reveste-se de um carater multidisciplinar, como normalmente acorre com estudos do tipo problem solving.

\subsection{O Plantio Direto no Paranáa}

Em 1971 iniciou-se, a nivel experimental, no Brasil, a pratica do Plantio Direto, que consiste basicamente na semeadura sobre os restos da cultura anterior e de ervas, não havendo revolvimento no solo, exceto nos sulcos ou covas de semeadura. Isto significa que, a area onde vai ser efeluado o plantio näo sofre movimentaçăo (aração, gradagem, escarificaçăo), salvo onde são depositadas as sementes. Fara matar a vegetação remanescenté emprega-se herbicidas de dessecaçăo (manejo) e para a manutençăo da cultura "no limpo", utilizam-se os 
herbicidas residuais ou de pós-emergência. Além da elimininaçăo da vegetaçăo existente antes do plantio. através da açăo de herbicidas apropriados, Shear e price, citados por BENATTI (1977), se referem a colocaça de adubo, por ocasião do plantio, no sulco de semeadura.

Talvez a primeira referencia sobre o sistema seja aquela feita há mais de 20 anos, pelo professor Clibas Vieira, em Viçosa CMUZZILI, in: Iapar, 1981 , referindo-se aos beneflicios oriundos de sua utilizagão nos solos arenosos dos EUA. Porem, as primeiras pesquisas com este sistema, no Brasil, foram realizadas nos campos experimentais do antigo Instituto de Pesquisas e Experimentação Agropecuaria Meridional-Ministerio da Agricultura (Ipeame/MA) no ano de 1971, no Paraná CLondrina e Ponta Grossas.

Num interesse conjunto dos agricultores, pesquisadores e tecnicos, buscava-se uma alternativa que possibilitasse a continuidade da exploração agricola, porém de forma a minimizar as perdas de solo que vinham ocorrendo com o uso sucessivo do sistema tradicional de plantio. Junto à este esforço pioneiro, somou-se o interesse de empresas multinacionais em promover o sistema.

Foi assim que, através de um acordo entre o IPEAME e a companhia ICI Brasil S.A. CICIS, 0 sistema 
começou a se expandir, a partir de 1972. Neste ano, a ICI realizou as primeiras demonstracóes do Plantio Direto em lavouras de trigo e soja, no norte do Parana, esteriendo o sistema para os agricultores de outras regises, ja no ano de 1974

Nestes primeiros ensaios, procurou-se identificar diferenças de produtividade, de fertilidade e estado de agregação do solo. A Empresa Brasileira de Fesquisa Agropecuária CEmbrapal ainda realizou outros ensaios, observando a correncia de plantas daminhas para diferentes sistemas da movimentação do solo, na regiã de Ponta Grossa $(1972)$

Em 1976, atraves de um acordo com a ICI, o Institulo Agronómico do Paraná (Iapar) deu inf́cio a um projeto de pesquisa, comparando o plantio convencional com - direto, envolvendo diferentes rotaçóses de cultura, conforme relata MUZZILI Cin: IAPAR, 1981 .

Em 1977, num acordo de cooperaça tecrica com a Alemanha CIapar,GTZ, foi iniciado um projeto com vistas a estudar a erosão hidrica e desenvolver sistemas de preparo do 5010 e plantio que permitissem maior protecáo do solo contra a erosăo. Varias rotaços e coberturas verdes foram analisadas, enfocando-ss aquelas técnicas economicamente viáveis para as condi çoses do estado do Parana. Este 
projeto encerrou-se em 1984 e vários trabalhos, abrangendo uma serie de aspectos, roram elaborados erou publicados (DEFPSCH, 19834$).$

A partir destas pesquisas iniciais, o sistema de plantio direto tem despertado muita curiosidade, polemica e angariado um número crescente de adeptos, que se reflete nos expressivos aumentos de area e de culturas sob este regime de produça.

A evoluça da área cultivada através deste sistema, esta registrada na tabela 1.

Do total da area com plantio direto no Brasil, em 1988, 89\% pertenciam ao estado do Paraná, com predominancia na região dos Campos Gerais e, principalmente, nas culturas de soja e milho no verão e trigo no inverno. Em menor escala, as culturas de algodão, feifão, aveia, cevada, centeio, leguminosas de inverno para adubaçăo verde, além de pastagens de inverno, também săo plantadas no sistema direto. A area plantada com soja, milho e trigo al cançou 26.093 .619 ha no Brasil e 2.281.500 ha no Parará em 1987 (IBGE, 1989). Portanto, a area com plantio direto representa cerca de $3 \%$ do total plantado no Brasil e $11 \%$ no Paraná.

Observando a tabela 1 , percebemos que a euforia inicial deu lugar a retração na adosăo do sistema, 
logo que as dificuldades, principalmente com o maquinario e - controle de ervas, se fizeram sentir. As máquinas rão estavam adaptadas para o novo método de plantio e havia

Tabela 1 - Evolução da área chas sob plantio direto no Brasil e Faraná. Participação e indice de variaçăo $(\%$ da área no Paraná.

\begin{tabular}{|c|c|c|c|c|c|}
\hline \multirow{2}{*}{ ANO } & BRASIL & \multicolumn{4}{|c|}{ FARANA } \\
\hline & $\overline{A R E A}(\mathrm{ha})$ & AREA Chà & $\%$ & DO TOTAL & $\begin{array}{c}\text { VARI ACAO } \\
1 \% \\
\end{array}$ \\
\hline 1972 & 100 & 100 & & 100 & 900.00 \\
\hline 1973 & 1150 & 1000 & & 86.96 & 600.00 \\
\hline $19 / 4$ & 7900 & 7000 & & 88.61 & 214.28 \\
\hline 1975 & 24800 & 22000 & & 88.71 & 138.64 \\
\hline 1970 & 56800 & 52500 & & 92.43 & 21.90 \\
\hline 1977 & 47500 & 41000 & & 86.32 & 9.76 \\
\hline 1978 & 54000 & 45000 & & 83.33 & 140.00 \\
\hline 1979 & 121000 & 108000 & & 89.26 & 121.30 \\
\hline 1980 & 273250 & 239000 & & 87.47 & -26.36 \\
\hline 1981 & 220000 & 176000 & & 80.00 & 20. 14 \\
\hline $198 z$ & 260800 & 222000 & & 85.12 & -8.56 \\
\hline 1983 & 245900 & 203000 & & 82.55 & 42.86 \\
\hline 1984 & 338800 & 290000 & & 85.60 & 48.28 \\
\hline 1985 & 477200 & 430000 & & 90.11 & 32.56 \\
\hline 1986 & 605500 & 570000 & & 94.14 & 8.77 \\
\hline 1987 & 678200 & 620000 & & 91.42 & 10.48 \\
\hline 1988 & 766500 & 685000 & & 89.37 & \\
\hline
\end{tabular}

Fonte: ICI Brasil S. A., comunicaçăo pessoal. 
muito poucas informaçåses sobre a nova técrica. Á medi da que foram sendo testadas e selecionadas alternativas que solucionavam os problemas surgidos cmelhores plantadeiras, herbicidas apropriados ete. , os agricultores passavam a adotar esta tecrologia com mais segurança e a expansão voltou a se dar, a partir de 198e, de modo mais timido, porém, mais regular.

Sem dúvida, a principal motivaça para o emprego do plantio direto tem sido a necessidade de controle da erosão e a recuperação de solos degradados.

\section{4. Objetivos}

\subsubsection{Objetivo principal}

Para as condiços desta analise, pretende-se verificar, primeiramente, se durante a utilização contínua de um sistema de plantio convencional e outro designado 'direto', houve aumentos significativos das produçós obtidas na sola, milho e trigo sob o plantio direto, e comparar o lucro liquido e risco dos dois métodos de plantio.

Com isto, dentro do contexto em que as experiencias passadas servem de auxilio às decisos futuras, pretende-se prestar um auxilio a tomada de decisão do agricultor. 


\subsubsection{Objetivos especificos}

1 - identificar os coeficientes mais significativos na composiça de custos dos dois sistemas;

Z - verificar se as produtividades aumentaram com a continuidade do Plantio Direto;

3 - constatar se houve diferengas significativas nos custos e riscos;

4 - analisar as alteraçós no tamanho da area plantada com o sistema de Plantio Direto;

5 - verificar se o novo sistema de plantio reduz as perdas da produção em anos de falta ou má distribuição de chuvas. 


\section{E. ASFECTOS TÉCHICOS DOS SISTEMAS DE PLANTIO}

\subsection{Perdas de solo e água}

Apesar de contar com cerca de $42 \%$ de solos considerados resistentes à erosăo Clatossolo vermelno Escuro, Latossolo Roxo e Terrá Roxa Estruturadal, este é um dos problemas mais sérios na agricultura do estado do Päraná, devido à topografia acidentada, alta intensidade pluviometrica e manejo inapropriado do solo. Com a expansão das culturas anuais e, principalmente, do binómio soja $\mathrm{x}$ trigo, o solo chega a ser mobilizado duas vezes ao ano, acelerando enormemente o processo erosivo.

Este fenômeno tem crescido à taxas elevadas nas últimas décadas. A cobertura florestal, em torno de $84 \%$ até cerca de 60 anos atrás, não passa de $7 \%$ hoje em dia (SORRENSON \& MONTOYA, 1984). SIDIRAS (1983) informa que, em 1983, a área ocupada com trigo e soja no sistema convencibral no Paraná já era de 1,3 e 2,5 milhóes de hectares, respertivamente. Juntos com o milho, aumentaram de 2 milhoes de ha em 1960 para. 5 milhões de ha, em 1980. A area plantada com lavouras temporarias evoluiu de 565.340 
ha em 1940, para 5.501.161 ha em 1985, acompanhada por um respectivo aumento no número de tratores, de 65 para 99.143 unidades (IEGE, 1987 ).

Esta rápida 'modernizaçăo' da agricultura paranaense, sem deixar reservas ou matas remanescentes de proteça às nascentes, trouxe como consequencias nocivas a erosão, o assoreamento dos rios, a reduçăo da fauna e flora silvestres, perda da qualidade da água e do ar e alteraçóes de microclimas regionais (MONTOYA, 1984). Houve um aumento, em dois decennios, do coeficiente de variaçăo das precipitaçóes cde $1,4 \%$ - 1, $6 \%$ para $2,0 \%$ - 2, $9 \%$, no norte do Paraná (prineipal região desmatada). Isto indica que as precipitaçbes se tornaram mais irregulares, ocorrendo abundância ou escassez de chuvas em determinadas épocas CIAPAR, $1978)$

Devido à intensificação da exploração de culturas anuais, as interaç̧es ambientais com a produção tornaram-se mais significativas. Em 1976,77, a produção do trigo foi muito reduzida devido à seca, principalmente no norte e oeste do estado (IAPAR, 1978 ).

As principais práticas conservacionistas, quando utilizadas, săo o.plantio em contorno e a construçăo de terracos. O uso exolusivo do plantio em contorno não é suficiente para conter as chuvas de elevada intensidade, 
comuns no Paraná; a constrũ̧̧o de terraços e cara e provoca compactạ̧ão no solo. Além disso, se os terraços não forem bem construídos, acabam agravardo o problema e, mesmo em nivel, năo impedem o estágio inicial da erosão CSORRENSON \& MONTOYA, 1984 .

(A forma mais comum de erosão tem sido a laminar cpor escorrimerito superficiall. Ela depende da capacidade de infiltração do solo e da chuva. A natureza do solo influi no volume de enxurrada e na quantidade de elementos arrastados por ela. Isto está diretamente relacionado com a textura, permeabilidade e estrutura do solo e com a intensidade, quantidade e distribuição das chuvas (IAPAR, 1978). Considerando a impossibilidade de alterar estas caracteristicas. DEDECEK (1977) encontra a solução na escolha dos sistemas de cultivo, culturas e práticas conservacionistas. para a minimização dos efeitos da erosão, assim como BENATTI (1977), ELTZ (1977), MARQUES \& BERTONI (1961) e JONES (1958), que recomendam cautela na manipulação do solo, principalmente na época em que as churas mais erosivas coincidem com o solo descoberto; sugerindo que se evite a pulverização excessiva do solo. o sistema tradicional de cultivo implica no preparo excessivo do solo e na eliminação dos resíduos vegetais, o que acarreta elevadas perdas de solo. Como 
agravante, temos a coincidencia das epocas de preparo do solo e plantio das culturas de verăo, com a de maior intensidade $e$ frequência de chuvas, Coutubro-dezembros CBENATTI , 1977; MONDARDO, 1977; IAPAR, 1978; KEMPER \& DERPSCH, 19812.

MONDARDO (1977) se refere a' dados que indicam que mais de $90 \%$ da erosão durante o ciclo da soja, ocorrem nos primeiros 30 dias apos a emergencia das plantas. Confirmando isto, o relatónio do Programa de Manejo e Conservação dos Solos, do Iapar (IAPAR, 1978 ). mostra que para as culturas anuais csoja, trigo, milho e algodão), guase toda erosão se concentra no primeiro estágio de desenvolvimento das culturas, quando ocorre mais de $20 \%$ da erosividade anual das chuvas, na região de Londrina, na seguinte sequéncia crescente de susceptibilidade: algodão, soja, trigo e milho. Para ambos os sistemas de plantio, a maior perda de solo ocorreu no estágio inicial CI $\mathrm{CII}$ de crescimento das culturas. A soja, no estágio I, acusou $90,7 \% \in 46,4 \%$ de perda de solo, respectivamente nos sistemas convencional e direto. E interessante notar que o sistema de plantio direto foi responsável por uma economia de $71,7 \%$ no volume total de solo perdido.

A erosividade das chuvas diz repeito à sua 
capacidade de causar erosão e e determinada pela sua energia cirética total e intensidade máxima em 30 minutos (ELTZ, 1977). Um dos fatores mais determinantes da erosăo pela chuva, é o impacto das gotas de chuva no solo. Este impacto causa a degradação das particulas do solo. pulverizando-o. Assim, o que acontece é que as particulas menores passam a preenchier os espaços 1 ivres, formando uma crosta que impede a penetraç̃o da água e favorece o escorrimento superficial.

DANIEL (1981) situa a degradação da estrutura do solo como o primeiro e mais importante estágio do processo de erosão hídrica, que por sua vez, é a maneira mais critica de um solo perder sua capacidade produtiva CELTZ, 19773. Este fato é frequentemente mascarado pelo efeito da utilização crescente de fertilizantes CSORRENSON \& MONTOYA, $1984 ;$ MONTOYA, 1984 .

Calcula-se que o volume total de sedimentacão anual dos 6 principais rios do paraná, seja de 12,5 milhoes de toneladas. Com ele vêm juntos os insumos aplicados na produçäo agricola e que são agentes poluentes em potencial. Dados que relacionam as concentraç̧es médias mensais de nutrientes CCa, Mg, K, F, W e solidos em suspensão em Itaipú, provenientes do faraná, mostram que estes apresentam aumento expressivo em abril/maio e 
novamente em out/nov, precisamente nas ocasiões em que o solo está sendo preparado e os fertilizantes aplicados para - plantio de inverno e verão. As estimativas de perda dos macronutrientes $N, P e K$ são de $63.023,136.632$ e 351.130 t/ano respectivamente, a um custo anual de 316 milhões de dólares, para eitar apenas um tipo de custo proveniente da erOSä do SOlO CSORRENSON \& MONTOYA, 1984). Em termos reais, torna-se quase impossivel isolar e quantificar os custos da erosão, se nos detivermos em aspectos cono a degradação do solo e suas conseguiencias sobre a produtividade agrícola - diminuição da resposta esperada dos modernos insumos empregados - além dos custos sociais inevitáveis, em processos como incorporação de novas áreas, éxodo rural e diminuição da qualidade de vida CFUENTES in: IAPAR, 19813.

A susceptibilidade à erosão de um solo é aumentada pela aceleração da degradação, ocasionada pelo uso e manejo inadequados do solo. Dados do Iapar mostram que, para um mesmo tipo de solo, o fator de erodibilidade (K) variou de 0,149 a 0,381 (195\%, respectivamerte para um solo (LRd) de uso recente e antigo com trigo $x$ soja, CIAPAE, 1978). O cultivo intersivo do solo provoca alteraçóes nas suas propriedades físicas CMACHADO \& BRUM, 
1978 ; para MACHADO (1976), o efeito geral do cultivo é destruir a estrutura do solo.

Os latossolos tém geralmente alto indice de macroporos $(20 \%-30 \%$, mas com a mobilização do solo, a porosidade natural é alterada e se desenvolve uma rápida compactação na camada de 10 a $20 \mathrm{~cm}$ de profundidade do perfil. A estabilidade dos agregados em água desempenha um papel importante nesta alteração da porosidade natural e, para CORSINI (1974), ela está intimamente relacionada à compactação do solo, principalmente os de textura mais fina. Quanto maior a estabilidade dos agregados em água, maior a resistência à erosão; caso contrário eles tendem a desmanchar-se e a dispersar-se. São estas partículas que, finalmente, provocam a obstrução dos poros superficiais é a impermeabilização do solo à água e ao ar (MACHADO, 1976$).$

Amostras de solo previamente umidificadas, apresentaram agregados com maior estabilidade CRANDO, 1981 ; FERNANDES, 1976; MACHADO, 1976; SIDIRAS, 19843. Quanto mais seco estiver o agregado, a água tende a penetrálo com maior rapidez, provocando uma expansão desigual dos constituintes do agregado, fazendo com que ele se desmanche mais rapidamente. Quando exposto à açăo direta da água da chuva, a resistência do agregado é menor. Isto explica porque os solos úmidos resistem por mais tempo as 
enxurradas. RANDO (1981) demonstrou que o preparo e cultivo feitos com o solo úmido cro máximo $38 \%$ contribuiu na preservasão da estrutura do Latossolo Roxo distrófico.

Pesquisando o efeito dos sistemas de cultivo convencional e direto, na rotaçăo soja X trigo em áreas de 6 anos com o sistema convencioral cqueimando a palna do trigo) e 4 anos com o direto, MACHADO (1976) encontrou, para um LRd, valores de estabilidade e fndice de agregação do solo significativamente maiores para o plantio direto (1,28), quando comparado ao convencional $(0,86)$, resultado da irtensidade do trabalno mecanico e do grau de pulverização sofrida pelo solo.

Tamberm RANDO (1981) encontrou agregados menos estáveis em solo submetido ao cultivo convencional por mais de 10 anos (LRd), em Lavras. Comparando amostras de solo do ensaio com outras de campo nativo, RAMOS (1977) verificou que o sistema de nenhum preparo foi o que mais se aproximou do campo nativo, quanto ao estado de agregaçăo estabilidade dos agregados.

Varios pesquisadores realizaram estudos comparativos de perda de solo sob diversos sistemas de cultivo. Em todos eles, nos diversos tipos de solos analizados. as perdas de sol for fom expressivamente menores no sistema de plantio direto. 
Castro, citado por SORRENSON \& MONTOYA (1984), demontrou que as perdas de solo por erosão em cultivo mínimo csolo escarificado ou com apenas uma gradagem niveladoral, for am cerca de $40 \%$ menores que as observadas no cultivo tradicional. Ensaios do IAPAR mostram que, na safra de $1975 / 77$, as perdas de solo e água na cultura da soja, sob condições de chuva natural com declive de 4,5\%, num solo arenoso (Podzolico Vermelho Amarelo), foram de $19,8 \in 17,9 ; 2,66 \ominus 8,5 ; 0,2 \mathrm{~kg} / \mathrm{ha} e 1,1 \%$, para as condifóes de solo descober to com preparo convencional, soja no plantio convencional e soja no plantio direto, respectivamente. Considerando-se o nivel de $100 \%$ de perda para o solo descoberto, a perda relativa ao sistema convencional foi de $13,4 \%$ e ao sistema direto de $0,01 \%$

No mesmo ano, para o LRd com $8 \%$ de declive, mediu-se as perdas por erosão das parcelas sob diferentes culturas em rotacăo, sob chuva simulada. As perdas encontradas foram 7.425 e $2.099 \mathrm{~kg} / \mathrm{ha} C \Delta \%=71,7 \%$ para a soja no convencional e no direto; 4.668 e $3.260 \mathrm{~kg} / \mathrm{ha}$ $C \Delta=30,2 \%$ para o trigo, respectivamente para os dois sistemas de plantio. Estes dados evidenciam grande eficiencia no plantio direto da soja en resteva de trigo, no controle à erosào.

CASSOL (1977), t.rabal hando com o mesmo tipo 
de solo com $7.5 \%$ de declividade e uma camada de pal ha de 3 thra, em Ijui (RS), encontrou perdas de solo 4 vezes maiores no plantio convencional $(1, B$ tha) em relaçă ao direto (0,4 thas, para um volume de chuva anual de $937 \mathrm{~mm}$. No mesmo ano, em Campinas, num ensaio de 3 anos consecutivos com milro, BENATTI (1977) verificou que 0 plantio direto reduziu as perdas de $5010 \mathrm{em} 20 \%(3,11 \times 2,5$ thas, com os mesmos valores de perdas de água nos dois sistemas comparados. Em outro tipo de solo, mais arenoso CPodzolizado de Lins e Marilia, var. Mariliale com 10,8\% de declive, a redução de perda de solo ocasionada pelo plantio direto foi de $63 \%(40,94 \times 13,39$ t/ha) e de água foi de 33\% $(143,68 \times$ x $95,8 \mathrm{~mm}$. Explica estes efeitos notaveis do controle da erosão proporcionados pelo plantio direto, pela menor pulverizaçăo dos agregados e pela proteção oferecida pelos residuos vegetais das culturas anteriores, deixados na superficie.

Também t.rabalhando com dois tipos de solo, MONDARDO (1977) verificou uma economia de $93,6 \%$ nas perdas de solo e $93 \%$ na de água na soja, e $100 \%$ em ambas as perdas no trigo sobre Latossolo Vermelno Escuro (5\% de declive); $63 \%$ na soja e $29 \%$ no trigo, sobre LFo (8\% de declives. Utilizando solo franco arenoso CLateritico Bruno Avermel hado distroficol, com $12 \%$ de declive, em Gualba 
(RS), ELTZ (1977) encontrou valores de perda de solo de 0,3 e 0,05 tha $C \Delta=83,3 \%$, no período de 1 ano sob a cultura da soja sobre palha de trigo correspondente a 1,5 t/ha. O trigo, no convencional, ocasionou perda média de 1 , 28 t/ha de solo. A soja em plantio direto apresentou perdá de solo 6 vezes menor do que no convencional e 25,6 vezes menor do que o trigo no convencional, embora a erosividade da chuva tenha sido 2,4 vezes maior durante o ciclo da soja.

A tabela $\vec{Z}$, a seguir, resume os resultados encontrados por SIDIRAS (1984), mostrando uma perda de solo 10 vezes menor, sob plantio direto.

Tabela 2 - Reducăo da espessura do horizonte A e perdas de solo em sistemas de plantio convencional e direto, em rotaçōes de diversas culturas. LRd, $6 \%$ de declive.

\begin{tabular}{|c|c|c|c|}
\hline \multirow{2}{*}{$\begin{array}{l}\text { Sistemas } \\
\text { de Flantio }\end{array}$} & \multicolumn{2}{|c|}{$\begin{array}{c}\text { Reduça da espessura } \\
\text { do horiz. A }\end{array}$} & \multirow{2}{*}{$\begin{array}{c}\text { Perdas de solo } \\
\text { tharano }\end{array}$} \\
\hline & $\mathrm{cm} / \mathrm{s}$ anos & $\mathrm{cm} / \mathrm{ano}$ & \\
\hline Corverrci onal & 3.48 & 0.896 & 68.2 \\
\hline Direto & 0.3 & 0.06 & 0.9 \\
\hline
\end{tabular}

Fonte : SIDIRAS, 1984. 
SORRENSON \& MONTOYA (1984) se referem a trabalhos realizados pelo IAFAR, para uma declividade de $6 \%$, que estimam perdas de até 700 t/ha/aro no sistema comvencional ( 1 araçăo de disco e 2 gradagens niveladoras), caindo para 400 thalano se forem efetuadas curvas de nivel, e para 100 t/ha/ano se for adotado terraceamento.

De modo geral, a conclusão e a de que quanto menos o solo for movimentado, menor será a erosão ocasionada, ou seja, quanto maior a degradacão do solo, maior será o prejuízo por erosão. MARQUES \& BERTONI (1961) consideram que "o grande problema e conciliar economicamente os interesses do aumento da produção agricola com aquueles da preservação da integridade do solo". Para três intensidades diferentes de mobilizaçăo ca araçōes, 1 aração e 1 aração de superficiel, encontraram valores de perdas de solo de $16,7,14,5$ e $8,3 \mathrm{t}$ /ha, no periodo de $1944 / 45$ a 1956/57, com precipitação anual média de $1.117 \mathrm{~mm}$, no Arenito de Bauru. Confirmando este resultado, o Iapar publicou dados referentes a um ensaio realizado em $1976 / 77$ (IAFAR, 1978), que reproduzimos ra tabela 3. 
Tabela 3 - Influencia de sistemas de preparo do solo nas perdas por erosăo, com Ehuva simulada. LRd $1976 / 1977$.

\begin{tabular}{|c|c|c|c|c|}
\hline \multirow{2}{*}{$\begin{array}{c}\text { Preparo do } \\
=010\end{array}$} & \multicolumn{2}{|c|}{ Perda de Solo } & \multicolumn{2}{|c|}{ Perda de Agua } \\
\hline & thlia & Indice & $\%$ & Indice \\
\hline $\begin{array}{l}\text { grade pesada + } \\
2 \text { grade nivel. }\end{array}$ & 5.68 & 100.0 & 31.4 & 100.0 \\
\hline $\begin{array}{l}\text { subsol ador }+ \\
\text { e grade nivel. }\end{array}$ & 9.20 & 162.0 & 21.4 & 68.2 \\
\hline $\begin{array}{l}\text { aração }+ \\
\text { e grade nivel. }\end{array}$ & 1.48 & 26. 1 & 9.3 & 20.6 \\
\hline sem preparo & 0.67 & 11.8 & 30.8 & 98.1 \\
\hline
\end{tabular}

Fonte: Relatorio ténico anual - Programa de manejo conser vação do solo. IAPAR, 1978.

Estes dados se referem a parcelas submetidas a diferentes intersidades de mobilizaça do solo, sem o posterior plantio de qualquer cultura (solo sem protecão). A perda elevada de água no solo sem preparo reflete problemas de compactação, uma vez que os latossolos săo solos que oferecem excelentes condiçóes naturais de infiltração da àgua.

$$
\text { Fesquisando o grau de compactaça do solo, }
$$
mostrado pelas alteraçós nos parâmetros densidade do solo. porosidade total, macro e microporosidade, MACHADO \& BRUM (1978) encontraram um altio grau de compactação nas camadas 
superficiais cate $15 \mathrm{~cm}$ do solo submetido ao sistema convencional. Estudando 4 condiçöes diferentes de uso $\theta$ manejo do Led com relevo ondul ado, na rotação soja $X$ trigo (4 amos com P.d. e 6 anos com P.c.) na regi ăo das Missões (RS), encontraram valor de densidade do solo significativamente maior para o plantio convencional $\left(1,35 \mathrm{~g} / \mathrm{cm}^{3}\right)$ nos primeiros $15 \mathrm{~cm}$ de profundidade do solo $\mathrm{c} 1,21 \mathrm{~g} / \mathrm{cm}^{3}$ para o plantio diretos. Estes valores apresentaram relaça direta e negativa com os de porosidade total, macroporosidade e teor de materia organica. Nas camadas mais profundas $(15-30 \mathrm{~cm}$ näo observaram diferenças significativas em relaçăo à porosidade, para os 4 tratamentos. A diminuição da macroporosidade foi acompanhada por inferior aumento na microporosidade, .resultando finalmente numa menor porosidade total.

Estrutura do solo, textura e materia organica são os fatores que mais afetam a densidade do solo. Esta varia entre 1,0 até $1,6 \mathrm{~g}^{\mathrm{cm}} \mathrm{m}^{3}$ em solos argilosos (FANDO, 1981), sendo que a diferança em volume total de poros é o que mais se reflete nesta variação. Conforme observaram RANDO (1981) e SIDIRAS (1984), esta relaf̧̃̃o entre porosidade total e densidade do solo é dinamica, ao longo da estação de crescimento das culturas. Apos o preparo do solo, devido à pulverização sofrida, a densidade 
$\Leftrightarrow$ baixa e a porosidade total e alta, invertendo-se a situaçácom o passar do tempo.

Os valores médios das densidades do solo (LRd) medidas por RANDO (1981) 1090 após a aração $e$ gradagem do solo, for am $1,07 \mathrm{~g} / \mathrm{cm}^{3}$ para 0 solo cultivado no sistema convencional $\theta 0,98 \mathrm{~g} / \mathrm{cm}^{3}$ no solo sob mata. A amplitude diferencial foi maior exatamente na camada de 21-48 cm, com menor volume de poros, refletindo a compactaçăo exercida pelo trabalho das máquinas agricolas. A redução na porosidade total foi de $11 \%$ parß a solo manipul ado.

Os resultados obtidos por SIDIRAS (1984) em LRd, mostram que a densidade aparente do solo sob plantio direto na camada de $3-10 \mathrm{~cm}$ foi $19 \%$ maior do que no plantio convencional, sendo também maior $(18 \%$ na camada de $12-20$ cm, contrariando frontalmente os resultados obtidos por MACHADO \& BRUM (1978), ja mencionados. Os valores ercontrados estão dentro do 1 imite considerado ideal para o desenvol vimento das raizes de soja $c_{1}, 1 \leq \mathrm{d} \leq 1,5 \mathrm{~g} / \mathrm{cm}^{3}$, e foram obtidos logo apos a colheita do trigo. No entanto, observa que apus a semeadura, a situacão se inverte, com maiores valores de densidade do solo no preparo convencional, principalmente na camada de $20-30 \mathrm{~cm}$. For esta razão, não considera relevante a opinião de que o plantio 
direto compacta o solo, ao longo prazo.

CORSINI (1974), trabalhando com dois tipos de solos submetidos ao cultivo anual durante mais de 50 anos e não cultivados naturais, verificou que o cultivo intenso provocou a formaça de uma camada com sérios problemas de adensamento para a serie Jaboticabal, a $20 \mathrm{~cm}$ de profundidade, melhorando no entanto as condiçós de permeabilidade nas camadas mais profundas. Na serie Santa Teresa, o cultivo intenso propiciou melhoras nas condiçoses de condutividade hidráulica cusada para identificar as diferenças estruturais nas diversas camadas do solo ao longo de todo o perfil e principalmente nas camadas superiores.

Verificando o. efeito da movimentação de máquinas em dois tipos de solo, um húmico (Argiaquollse outro arenoso (Hapludolf), FERNANDES (1976) observou que, para a camada de $10-20 \mathrm{~cm}$, o solo húmico acusou maiores níveis de compactaçăo, com a diminuição no tamanho dos poros mais acentuada, neste solo mal drenado. No entanto, este efeito foi minimizado quando o sistema utilizado não incluiu movimentaça do solo, onde a porosidade não foi afetada pela movimentação do solo ou pela compactação da chuva. Porém, os dois sistemas de cultivo pouco diferenciaram em relaçăo à quantidade de água disponível 
para as plantas, sendo que no solo arenoso, o sistema convencional foi o que apresentou os menores valores. A permeabilidade foi estatisticamente diferente cao nivel de 1\%, com maior eficiencia do plantio direto no solo arenoso, que tambem teve a maior taxa de infiltraçăo, para os dois solos (medida nos primeiros $10 \mathrm{~cm}$ dos perfis Semelhantemente aos resultados já apresentados de MACHADO \& BRUM (1978), não encontrou al teraçठ̄es nas caracteristicas físicas dos solos, nas camadas mais profundas que $30 \mathrm{~cm}$. Observou ainda, que a movimentaçăo favoreceu a porosidade total na camada de $0-10 \mathrm{~cm}$ de solo.

A tendência dos solos cultivados é apresentarem quedas no teor de matéria orgánica, afetando a estabilidade dos agregados existentes nas camadas superficiais do solo.

MACHADO (1976) constatou que o plantio direto preveniu a perda de materia orgânica do solo, apresentando teores de $226 \%$ e $328 \%$ a mais do que o plantio convencional, nas profundidades de $0-15 e 15-30 \mathrm{~cm}$, além de apresentar maiores taxas de infiltraça do que o solo com campo e cultivo convencional. As correlaçßes que encontrou entre matéria orgânica e estabilidade dos agregados matéria organica e macroporosidade, foram positivas $e$ elevadas $\mathrm{Cr}=0,82$ er $=0,84 \mathrm{~J}$. Isto quer dizer que siste- 
mas de manejo que reduzam as perdas de materia orgânica, podem ser beneficos na redução da erosão do solo. VIEIRA (1984) apresenta resultados em que a redução de materia organica esta diretamente ligada a perda e movimentação do solo. Numa condiç̃o de solo (LRd) arado, submetido a 4 gradeações e queima da palha, ocorreu uma perda de 18,03 tha de solo e $657 \mathrm{~kg} / \mathrm{ha}$ de materia orgânica; contrastantemente, numa condição de não movimentação com preservação da palha na superficie, os niveis de perda dos dois materiais foram $0,14 \mathrm{t} / \mathrm{ha}$ e $5 \mathrm{~kg} / \mathrm{ha}$, respectivamente.

- aumento na densidade das particulas do solo cultivado, foi atribuido por RANDO (1981) à redução sofrida de matéria orgarica. Quanto ao problema da compactação, sugere que a aração seja feita a profundidades variadas, com adição de matéria orgánica nas camadas superficiais, restringindo-se ao máximo possivel o uso de máquinas pesadas no cultivo do solo.

Para KEMPER \& DERPSCH (1981), o surgimento da camada compactada é acelerado pelas chuvas intensas $\theta$ pela redução da matéria orgánica. Embora possa ser quebrada por uma nova movimentaçăo do solo, esta camada sempre reaparece, assim que o solo se acomoda. Ela impede a infiltração da água, com a consequente perda do horizonte A superficial. pelo arrastamento do material nas 
enxurradas. Portanto, o aumento da infiltração 6 uma importante medida no controle da erosão.

As vantagens advindas da movimentação do solo para o plantio, que se fazem sentir no curto prazo, podem se transformar em problemas serios com a continuidade desta prática. O cultivo sucessivo do trigo e da soja, em particular, embora ofereça certos beneficios, requer a utilização de práticas mais racionais de manejo do solo.

\section{2. O papel da cobertura vegetal}

A permanéncia de uma camada vegetal superficial é uma caracteristica de extrema importáncia para o sucesso do sistema de plantio direto. Em seguida. passaremos a descrever as principais interaços desta cobertura com o processo produtivo.

\subsection{1. Àgua e temperatura}

A cobertura morta atua como agente isolarte, impedindo oscilaçóes bruscas na temperatura do solo, alem de exercer proteção direta contra o impacto da gota de chuva sobre o solo nu e do vento. Com isto, diminui a evaporação da água na camada arável do solo, constituindo uma vantagem em épocas de estiagem.

KEMPER \& DERPSCH $(1981)$, mostram que para o ano de 1979, após 14 dias do plantio de trigo em solo seco 
CLRd, Londrina), $98 \%$ das plantas no plantio direto haviam emergido, contra apenas $15 \%$ no plantio convencional. Estas diferencas desapareceram, após uma chuva de 26mm durante 18 horas.

Estudando a cultura do trigo, VIEIRA (1984) enxergou uma vantagem nitida para o sistema direto de plantio no norte do estado do Parana, principalmente devido à melhor retenção de umi dade no solo. Nesta região comum a ocorrencia de perídos secos no inverno, com deficits hidricos no solo. As diferenças se fizeram notar desde a germinação e emergéncia das plantas, favorecidas pela maior disponibilidade de água, melhor contacto do solo com a semente e menores oscilaçōes na temperatura do solo.

\section{Resultados similares foram obtidos por}

BAKAJEV (1981), pesquisando uma rotação de pousio-trigotrigo-trigo, por um perfodo de 12 anos no norte da Rússia (Kazaquistãos. Durante todo o ciclo do trigo, nas condições de estepe semi-árida desta região, a disponibilidade de água de $0-10 \mathrm{~cm}$ de profundidade, foi sempre maior nas parcelas com maior volume de palha criveis de $0,1,2,4$, e 8 thas. O trigo plantado nestas parcelas foi melhor suprido de água, nas fases criticas de seu desenvol vimento. Além dos acréscimos consistentes no estoque de agua 113,3 para $19,9 \mathrm{~mm}$, as parcelas cobertas por palha tiveram menor 
amplitude térmica ao longo dos meses, medida nos primeiros $20 \mathrm{~cm}$ do salo.

ORTOLANI (1977), encontrou diferencas estatisticamente significativas $61 \%$ no número de plantas de milho emergidas no $5^{\circ}$ e $6^{\circ}$ dias após a semeadura, maior no plantio direto devido a maior umidade no solo. Observou que os sulcos de plantio, neste sistema, apresentavam-se saturados, o que era visivelmente menos pronunciado nos outros tratamertos.

MUZILLI (1983) verificou uma maior velocidade de emergência e desenvolvimento mais uniforme vigoroso das plantas de milho sob plantio direto, devido à maior retenç̃o de umidade, sobretudo nos $10 \mathrm{~cm}$ superficiais do solo. Destacadamente nos anos de ocorrencia de estiagem, obteve uma população inicial mais elevada por unidade de área. Estes resultados for am confirmados por CASSOL (1977), no Rio Grande do Sul.

JONES (1958), medindo a disponibilidade de água no perfil do solo (Silt Loam a 15 e $47,5 \mathrm{~cm}$, nas diversas fases do desenvolvimento do milho no perído de $1960 / 65$, encontrou valores sempre maiores nas parcelas com plantio direto, com as maiores diferenças na zona de utilizaça das raizes $(47,5 \mathrm{~cm}$. As diferenças no crescimento foram facilmente percebidas desde o inicio do 
desenvolvimento das plantas, sendo mais expressivas em anos de seca ou má distribuição de chuvas.

SIDIRAS $(1984)$ constatou aumentos de $31 \%$ $20 \%$ no volume de agua encontrado nas camadas de $3-11 \mathrm{~cm} e$ 12-20 cm, de um Latossolo Roxo submetido ao plantio direto, quando comparado ao plantio convencional. Atribuiu este resultado à melhoria na estrutura cmaior estabilidade dos agregados em águas, à diminuição na porcentagem dos macroporos e ao incremento de húmus na camada superficial Cdevido à cobertura mortas.

Em outro trabalho (SIDIRAS, 1983), verificou que o plantio direto apresentou sempre maiores valores de água disponivel nas diversas profundidades amostradas $636 \%$ a $45 \%$ a mais3 somente no plantio convencional houve deficits hidricos $(0-40 \mathrm{~cm}$ de profundidades, em alguns períodos do cultivo.

Num ensaio de 7 anos, submetendo a cultura do milho a 2 tipos de solo Chúmico e arenosol em Indiana (EUA), com 3 sistemas de cultivo diferentes, FERNANDES (1976) concluiu que a quantidade de agua e a estrutura dos solos, foram diretamente afetadas pelos sistemas de cultivo. O cultivo mínimo (preparo superficial do solo) foi - que proporcionou maiores valores de água diponivel, na camada de $10-20 \mathrm{~cm}$ do solo arenoso. 
A cobertura vegetal pode afetar a taxa de infiltração, e com isto influir no processo erosivo do so10, conforme detalhado no item anterior. SIDIRAS (1984) observou uma relação direta e positiva entre a taxa de infiltração e grau de cobertura da superficie, encontrando as taxas mais altas sob palha da aveia $690 \%$ de area cobertas.

No experimento desenvolvido por KEMPER \& DERPSCH (1981), todas as coberturas mortas apresentaram melhores taxas de infiltração de água do que o trigo c $421 \%$ no LRd e 6e8\% na TR, para as maiores diferenças . DERPSCH (1986) diz que uma cobertura de $100 \%$ levou a um nivel de infiltração de $100 \%$. Tambem BAKAJEV (1981) observou que, para um volume de palha de 0,2 e 4 tha as taxas de infiltraça médias, em trés periodos de 4 anos cada, foram $46,3 \mathrm{~mm} / \mathrm{h}, 178 \mathrm{~mm} / \mathrm{h}$ e $185 \mathrm{~mm} / \mathrm{h}$, respectivamente. CASSOL (1977) conclui que a permanencia dos restos de cultura sobre o solo (3 thal, além da não movimentaça deste, propiciou ótima proteção contra os efeitos da erosão.

No entanto, em anos frios, úmidos e no caso de ocorrencia de geadas, os efeitos resultantes no plantio direto podem ser nocivos, com quedas drásticas na produça total obtida. Isto foi relatado por vários autores, entre eles BAKAJEV (1981), FERNANDES (1976) e VIEIRA ( 1984 ). 
Para as condiços do Corn Belt americano, onde a germi naçáo e desenvol vimento do milho ocorrem sob baixas temperaturas $\left(15^{\circ} \mathrm{C}\right)$ e eventuais geadas, KOHNKE (1966) diz que as produçß̌es geralmente sofrem decresscimos à medida que aumenta a cobertura sobre o solo. Relaciona isto à maior quantidade de água no solo conservada ate a primavera Catrasando o plantio do milhos, não permitindo que a temperatura do solo se eleve, sendo mais evidente para os solos de textura fina.

Além disso ressalta que, inversamente ao que ocorre quando os residuos são incorporados ao solo, nas con diç̧es de cobertura da superficie do terreno, a decomposição rapida da palha compete em oxigênio com a cultura, podendo causar serias limitaçóes, se o pico da taxa de decomposicão coincidir com o picoe da necessidade de oxigênio pela planta. Relembrando, isto se da um condiçós de regiôses frias e com pouca intensidade de radiação solar. Apesar da pouca espessura da palhada e da boa distribuif̧ão de chuvas, DANIEL (1981) se refere a menores perdas de umidade do solo sob plantio direto. Porém, tanto no regime seco (sem irrigação) quanto no úmi do (com irrigaça), este sistema apresentou valores maiores ou iguais de perda de umidade no solo, na fase final do ciclo da cultura (maturação). 
Contrariamente aos que afirmam que o solo cultivado oferece menor disponibilidade de água para as plantas, RANDO (1981) concorda com a Iiteratura que diz que a materia orgánica, em solos argilosos, tende a reduzir o teor de agua disponível, em favor da aeração. Alerta para a compactaçăo sofrida pelos solos que sofrem maior movimentaఢุ̃.

Apesar das variaçós nos fatores externos (chuva, seca, intensidade de insolação), ORTOLANI (1977), verificou que a temperatura do solo sob plantio direto manteve-se constante, aspecto de grande importancia para o desenvol vimento da cultura em estudo (milho). Embora DANIEL (1981) não tenha encontrado diferencas de temperatura no solo sob plantio direto ou convencional, reconheceu que as amplitudes diárias da temperatura foram sempre menores no primeiro sistema.

A temperatura do solo e a umidade são fatores determinantes no desenvolvimento dos microorganismos do solo, sendo a cobertura morta uma fonte de energia para esta população. Este aspecto assume grande relevancia para as regises tropicais. Dados do IAPAR (1978), mostram que em janeiro de 1979 , a temperatura do solo à uma profundidade de $2 \mathrm{~cm}$, era de $50,8^{\circ} \mathrm{C}$ no solo descoberto, caindo para quase a metade $625,8^{\circ} \mathrm{CS}$ no solo 
coberto por palha. Conforme o tipo de cobertura vegetal, a variação na temperatura do solo pode ser maior ou menor, principalmente devido à coloração da palha e seu efeito na reflexão dos raios sol ares (KOHNKE, 1966$).$

Procurando identificar as diferencas ma atividade biológica do solo, DERPSGH (1984) realizou diversas contagens na população de anelidios (minhocas’, artrópodos e produção de $\mathrm{CO}_{2}$ no solo. Um ano e meio apús a instal ação do ensaio (LRd), a população de anelídios de 0-10 cm de pro fundidade foi de $5,8 / \mathrm{m}^{2}$ no sistema convencional e $13,0 / \mathrm{m}^{2}$ no direto (média de 36 repetiçoses); após 4 anos, numa faixa de $0-30 \mathrm{~cm}$ de espessura, encontrou $3,2 \mathrm{minhocas} / \mathrm{m}^{2}$ no sistema convèncional, contra $27,6 \mathrm{minhocas} / \mathrm{m}^{2}$ no direto (média de 12 repetiföes). O numero de artrópodes foi enormemente diferente, correspondendo a 7 unidades para o plantio convencional ate 192 no direto cem amostras de 300 $\mathrm{cm}^{3}$ de solos, variando conforme a rotação de culturas praticada. Quanto à produção de $\mathrm{CO}_{2}$ no solo, em mg $\mathrm{CO}_{2} / 1 \mathrm{OOg}$ solo, esta variou de $21 \%$ no plantio convencional para $51 \%$ no direto, quando comparados ao solo com cobertura verde permanente $100 \%$. Estes resultados refletem os benefíios advindos da maior umidade $e$ menor amplitude termica observadas no plantio direto, proporcionadas pela cobertura morta. 
Neste ensaio, o crescimento do trigo e da soja em plantio direto foi sempre melhor, logicamente com maior consumo de água. Mesmo assim, a água encontrada no solo foi sempre superior no plantio direto, prineipalmente nas épocas secas. Nestas ocasiões, demorou muito mais tempo para que a água do solo caísse abaixo do ponto de murcha, no plantio direto $\left(30^{\circ}\right.$ dias, nas camadas até $20 \mathrm{~cm}$ de prof undidade. Pelo exposto, verifica-se que o impacto ecologico do uso do plantio direto foi menos prejudicial, apresentando niveis de atividade biologica no solo mais próximos do solo sob condiç̃es de cobertura natural.

\subsubsection{Fertilidade}

A continuidade do uso do sistema de plantio direto, possibilita a manutençăo erou elevação da materia organica no solo. MUZILLI $(1983)$ encontrou valores significativamente maiores na matéria orgânica da camada superficial do solo $\mathrm{CO}-1 \mathrm{~g} \mathrm{~cm}$ sob este sistema, independentemente da rotação de culturas realizada e, praticamente, os mesmos valores na camada arável do solo Cate $30 \mathrm{~cm}$ que no sistema convencional com incorporação da pal ha.

Embora a quantidade de materia orgânica tenha sido praticamente a mesma nos dois sistemas, a 
qualidade foi bastante diferente. As gramineas cmilho e trigos manifestaram grande deficiencia de nitrogenio sob plantio direto, presente em menores proporçß̋es nas folhas destas especies vegetais, com colmos mais finos, menor tamanho das espigas, maior quebramento de plantas no campo e menor produtividade de grãos, tal como observaram outros autores (KONDORFER, 1984; BAKAJEV, 1981 ).

Isto se explica, em parte, pela maior umidade existente no solo sob plantio direto, que contribui para a maior lixiviação de nitratos (KINJO, 1978 ) menor taxa de nitrificação (temperaturas mais amenas). A menor evaporação de água reduz o movimento ascendente dos nitratos, a atividade da enzima presente nos restos de cultura (urease) sobre as perdas de amónia e mais intensa e além disso, a velocidade de mineralização da materia organica e menor. Após 12 anos de observação, BAKAJEV (1981) comeluiu que ao aumento do volume da palha, acompanha um significativo acúmulo da matéria orgânica no solo e uma reduçăo na taxa de nitratos.

Prevalecendo esta situação, a tendência é de uma necessidade de maior adubação nitrogenada. Porém, a rotaça com legumi nosas que reponham o nitrogenio no solo ameniza, ou ate mesmo anula, estes efeitos negativos. 0 milho em rotação com a soja apresenta melhor 
desenvolvimento, com as plartas mais verdes $e$ maior produtividade CMUZILLI, 1983; MARQUES \& EERTONI, 1961 ; SORRENSON \& MONTOYA, 1884J. Estudando rotaçÖes com coberturas verdes e cereais de inverno, DERPSCH (1984) conseguiu as melhores produtividades apos aveia preta (milho e feijão), tremoço branco e ervilhaca peluda (milho), com os piores rendimentos para as rotaçöes com cereais (trigo, aveia e centeio). O efeito residual do $N$ na rotaçăo tremoço branco antes do milho chegou a $90 \mathrm{~kg}$ de N, dispensando a adubação nitrogenada.

Avaliando o experimento objeto do presente estudo, MUZILLI (1983) diz que, após 4 anos de cultivo em LRd, os valores de $\mathrm{PH}$ no plantio direto foram superiores aos verificados em plantio convencional, principalmente nos primeiros $10 \mathrm{~cm}$ da camada aravel, contrariando a observaça de outros pesquisadores, que identificaram uma tendencia a acidificação após alguns anos de cultivo sucessivo sob plantio direto, devido à acumulação de matéria orgânica CSHEAR \& MOSCHLER, 1969 .

Os resultados das análises químicas efetuadas por MACHADO (1976), nas profundidades $0-15$ e $15-30 \mathrm{~cm}$, evidenciaram diferenças acentuadas entre os tratamentos, com teores mais elevados de $P$, materia orgánica, $K, S$, bases trocáveis (T), saturação de bases $(V), C a$ e $\mathrm{Mg}$. Năo 
se pode esquecer que nas parcelas de plantio direto o calcário não foi incorporado, permanecendo sobre a palha e, por isto, interferindo nos valores encontrados dos dois últimos elementos. Quanto ao aluminio, encontrou maiores quantidades no solo sob plantio convencional, quando comparado com o das parcelas de campo virgem cque não receberam calagem. As diferenças de $P, K$ e materia organica foram de $50 \%, 52 \%$ e 56\%, medidas de $0-15 \mathrm{~cm}$ do perfil, provavel mente devido às menores perdas de solo; percebeu que a perda da fertilidade acelerada, no sistema convencional de plantio.

Easeado no mesmo tipo de resultado, MUZILLI (1983) sugere uma economia de até 50\% na adubação fosfatada no plantio direto, uma vez alcançado o limite critico deste nutriente no solo. RAMOS (1977) constatou um expressivo aumento nos teores de fósforo na camada de $0-5 \mathrm{~cm}$ de solo para o plantio direto CG1 ppm X 16,3 ppm no plantio convencionals; idem para o potássio, elevado em $33 \%$.

BAKAJEV (1981) não encontrou qualquer relação entre o $P$ disponivel e o volume de palha sobre 0 solo. Sendo este elemento praticamente imovel ao longo do perfil, uma vez que fortemente adsorvido pelos colbides particulas do solo, sua maior acumulação em plantio direto se explica melhor pela não movimentacão do solo e menor 
superficie de contacto, consequentemente, menor adsorfão. As perdas deste nutriente estão associadas ao arraste da camada superficial do solo pelas enxurradas, fenômeno praticamente nulo quando se trata de plantio direto.

A constatação de maior eficiencia na utilizaçå de $P$ pelas plantas de milho, com maiores niveis do elemento presente em suas folhas, deve-se a maior umidade, que favorece a taxa de difusão do $P$ até as raizes (MUZI LLI, 1983 ).

2.2.3. Controle de ervas

Quando o solo sofre movimentação e as raizes e sementes de plantas infestantes săo expostas, consegue-se, na maioria das vezes, uma boa adequaça do terreno para o plantio e controle das ervas que se desenvol vem durante o ciclo da cultura, através da operação de cultivo. Considerando-se que esta situação não se verifica quando se trata de plantio direto, compreende-se a importáncia da utilização racional dos herbicidas, alom dos outros metodos para o controle de ervas. Este aspecto crucial para que o sistema se torne viavel, em termos de produção e custo.

MARQUES \& BERTONI (1961) concluiram que quanto mais praguejado for o terreno, menos vantajoso se 
apresenta o sistema de preparo do solo apenas no sulco de plantio. Em termos de produçăo, o melhor resultado obtido pelo uso do arado revolvedor residiu no fato do melhor controle de ervas propiciado. A oscilação total da produção, nas areas praguejadas, ficou na ordem de $46 \%$, bem superior às áreas com pouca infestação. Neste estudo, não foram utilizados herbicidas, tampouco rotaçōes com espécies fitotoxicas.

BAKAJEV (1981) relata que no trigo plantado no $1^{\circ}, 2^{\circ}$ e $3^{\circ}$ ano consecutivo sob plantio direto, houve um incremento na infestação de aveia sel vagem, proporcional ao volume de palha nas parcelas. As outras ervas não foram afetadas pela cobertura morta.

ALMEIDA (1985) procurou identificar os efeitos alelopáticos dos residuos das culturas de inverno, para as condiçoses de Londrina (LRd) e Ponta Grossa CLV. Para isto, manteve fixa a sequencia das culturas de verão (milho-soja-sojal e trabalhou com tres niveis de uso de herbicidas: alto, moderado completado por capinas se necessáriol e nulo. No inverno utilizou aveia, tremoço, serradela, girassol, pasto e trigo. Observou menor infestação sob pasto, aveia, serradela e trigo, onde foi mais barato o uso de capina manual. Nos casos em que a infestação foi elevada (tremoço, girassol e pousio), 
justificou-se o uso de herbicidas. Detectou, ainda, o efeito alelopatico do trigo na cultura do milho, refletido na menor produção obtida, em comparação às outras coberturas mortas.

RAMOS (1977) diz que, de um modo geral, houve menor incidencia de invasoras no sistema de nenhum preparo do solo, priricipalmente nas entrelinhas, num experimento realizado pela Embrapa em Ponta Grossa CLV, em 1985. ALMEIDA (1985) atribui a maior infestaça, por vezes observada no plantio direto quando comparado ás terras sem cultura, ao revolvimento do solo que, mesmo reduzido, influencia na quebra de dormencia das sementes silvestres.

Analizando o grau de infestação no $1^{\circ}$ ciclo do experimento estudado na presente dissertação, ALMEIDA (1981) contou um numero médio de ervas $/ \mathrm{m}^{2}$ no valor de 12,2 para o plantio direto, contra apenas 3,9 no plantio convencional (considerando todas as rotaçäes), com maior predomináncia daquelas ervas sobre as quais os herbicidas têm pouco controle.

MUZILLI (1983) enfatiza que o controle de ervas não pode se apoiar exclusivamente na eficácia dos herbicidas, devendo se considerar a rotação de culturas como alternativa importante para este fim. Lembra que o uso sucessivo dos mesmos herbicidas tende a aumentar a 
populaçao de ervas resistentes, devendo-se buscar uma forma de quebrar este efeito de seletividade (ALMEIDA, 1981 ).

Após a formação de uma espessa camada de palha, consegue-se diminuir a infestaç̃o de ervas, que são abafadas por esta cobertura morta. Porém, esta camada não deve ser tal que impefa o bom funcionamento da semeadeira; por isto, e para que esta fique bem distribuida pelo terreno, fundamental o uso do picador de palha na col hedeira.

\subsection{Produti vi dade}

A germinação e o desenvol vimento inicial das plantas, são favorecidos pela maior quantidade de água disponivel e a menor amplitude termica no solo, sobretudo em anos de estiagem, resultantes da presença da cobertura vegetal no solo. O fato deste sistema evitar a desagregação da estrutura do solo, permite que haja um contacto mais estreito com as sementes, o que tambem contribui para minimizar o risco de um stand deficiente (VIEIRA, 1984 ). Consequentemente, MUZILLI (1983) cita uma economia de ate $15 \%$ nos gastos com sementes, alem da reduça dos $r i s c o s$ pela necessidade de replantio das lavouras.

De uma forma geral, as pesquisas com movimentação minima do solo indicam que algumas culturas 
apresentam uma diferença significativa na produção, em total contradição com o que diz ORTOLANI (1977). Por ém, este autor verificou que entre os diversos tipos de preparo do solo que comparou (5), apesar do menor desenvolvimento das plantas, o plantio direto foi o mais eficiente na conversão da materia seca em grãos e pendöes de milho, tendo o convencional apresentado o pior resultado. Além disso, o plantio direto apresentou um indice de tombamento de plantas no minimo $50 \%$ menor do que os outros tratamentos, fenómeno confirmado por MUZILLI (1983).

Tambem DANIEL (1981) concluiu que, a partir da fase de crescimento vegetativo, o milho sobre plantio direto passou a apresentar menores taxas de crescimento, provavelmente em beneficio de outros mecanismos de sua fisiologia. Não detectou qualquer influência direta e sistematica dos dois sistemas de plantio na produçã do milho, serido que o que realmente influiu no comportamento da cultura, foi a rotação com a soja. Em ambos os sistemas, esta rotação promoveu um maior crescimento do milho, exatamente como observaram outros autores, citados no item 2.2.2., que obtiveram, inclusive, melhores produtividades do milho em alguns casos. Estes resultados se referem a dados de apenas 1 ano, com pouca quantidade de palha formada para a cobertura, o que seguramente não permitiu 
que se observasse mais acentuadamente os efeitos do plantio direto sobre a cultura.

SIDIRAS (1983) encontrou rendimentos superiores $(33 \%$ para a soja sobre plantio direto, em compara-

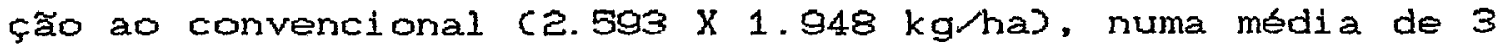
anos de estudo $(1978 / 81)$ em LRd, para o grão com $14 \%$ de umidade. Atribuiu este resultado ao maior número de plantas e, principalmente, ao maior peso das sementes, com coeficientes de correlaçăo crl positivos e elevados crespectivamente $r=0,74$ e $r=0,843$

Resultado semel hante foi notado por KEMPER \&: DERPSGH (1981) no LRd, para o grão com 10\% de umi dade, na safra de $1978 / 79$ (1.987 X $1.434 \mathrm{~kg} / \mathrm{ha}$. CASSOL (1977) encontrou diferença significativa na produtividade da soja plantada nos sistemas convencional $(3.124 \mathrm{~kg} / \mathrm{ha}$ e direto (4.671 $\mathrm{kg} / \mathrm{ha}$, no LRd com uma camada de 3 tha de palha.

Também para a soja, MARQUES \& EERTONI (1961) encontraram melhores produç̧es no sistema de plantio com movimentação do solo somente nos sulcos de plantio, na Terra Roxa legitima livre de ervas. Para o milho, nos primeiros 7 anos de avaliaçăo, notaram uma tendencia para um melhor stand final, nos sistemas mais intensivos de preparo do solo, notadamente para as situações em que a infestaça de ervas era maior, com as plantas de milho 
apresentando porte mais alto cporem, sem qualquer correlação entre este aspecto e a produção de grãos, conforme nos referimos no inficio deste item.

Quando trabalharam com solo mais pesado CTR legitimas, os melhores resultados foram obtidos com apenas 1 aração. Após 13 anos de cultivo do milho em TR legitima e livre de ervas, observaram que o sistema que apresentou melhores resultados de produçăo, foi o de preparo do solo nos sulcos de plantio. Curiosamente, este foi o pior sistema quando os solos foram o Arenito de Bauru e a TR misturada e praguejada csolos mais leves e/ou com infestação). Em Campinas, BENATTI (1977) verificou que as produç̧es do milho plantado sucessivamente por 3 anos, foram menores ou iguais no plantio direto. Neste experimento, o controle de ervas sob este sistema foi bastante deficiente, o que certamente prejudicou os resultados de produção.

Observando os efeitos de preparos do solo sobre a produção de soja e trigo no LRd CLondrina, $1971 / 73)$, RAMOS (1977) encontrou respostas positi vas quando - solo sofreu menos movimentação Capenas duas gradagens leves , semelhantemente aos resultados encontrados para o LVE (Ponta Grossa). Em outro ensaio (1973/75), as produtividades da soja e do trigo foram maiores quando em rotaça, 
sob plantio direto, embora a niveis não significativos.

Relacionando a quantidade de palna na superficie e a produção média anual de trigo ç anos), BAKAJEV (1981) encontrou os valores de $8 \%, 9 \%$ e $14 \%$ de incrementos na produtividade do trigo, para os correspondentes niveis de 1,2 , 2 t/ha de palha. Os efeitos positivos foram maiores para o nivel de 4 tha, ocorrendo decréscimos na produção quando se usou 8 tha de palha Capós significativo acrescimo nos primeiros dois anos do experimentos.

Diferenças na produção de trigo tambem foram detectadas por KEMPER \& DERPSCH (1981), num ensaio desenvolvido em LRd nos anos de $1978 / 79$ e $1979 / 80$, com uma vantagem de $15 \%$ para o plantio direto, conforme mostra a tabela 4. Não foi usado herbicida na safra de $1979 / 80$, o que provavelmente se refletiu no menor diferencial de ganhos apresentado pelo plantio direto, nesta safra.

Tabela 4 - Produção do trigo Ckg/has em P.c.e P.d. para o grão com $14 \%$ de umidade. Londrina, $1978 / 1980$.

\begin{tabular}{|c|c|c|c|c|}
\hline \multirow{2}{*}{ Tratamento } & \multicolumn{2}{|c|}{ Safra $78 / 79$} & \multicolumn{2}{|c|}{ Safra $79 / 80$} \\
\hline & $\mathrm{kg} / \mathrm{ha}$ & Indice & $\mathrm{kg} / \mathrm{ha}$ & Indice \\
\hline P.C. & 1.387 & 100 & 1.607 & 100 \\
\hline P.d. & 1.713 & 123 & 1.844 & 115 \\
\hline
\end{tabular}

Fonte : KEMPER \& DERPSCH, 1981. 
Com apenas 1 ano de instalação do ensaio comparativo entre os dois sistemas de plantio, em Bela Vista do Paraiso (1976/77, solo Podźlico Vermelho Amare10), a produção de palha e grão foi maior no plantio direto, respectivamente $3.575 \mathrm{x} 3.700 \mathrm{~kg} / \mathrm{ha}$ e $3.104 \mathrm{X} 3.189$ $\mathrm{kg}$ ha (Iapar, 1977). Já BENATTI (1977), em Campinas, encon trou produçóses de milho identicas ou menores no plantio direto, provavelmente devido ao controle ineficiente das ervas.

Nos $\dot{6}$ anos de duração de um ensaio em Virgínia (EUA), sobre solo siltoso CSilt Loam, a producăo de grãos de milho no plantio direto foi igual ou maior do que no convencional $(38,6 \%$ a mais em 1963 e $22,2 \%$ em 1965$)$. Alem disso, em todos os anos as plantas se apresentaram mais altas, e com maior peso seco, em 5 dos 6 anos. 


\section{MATERTAL E MÉTODOS}

\subsection{Material}

A análise comparativa de lucro liquido e risco baseou-se em séries historicas de um ensaio multidisciplinar de longa duração (1己 anos?, no Iapar em Londrina - PR.

Os dados referentes a precos de insumos e produtos foram obtidos nas publicaçoses da Secretaria de Agricultura do Estado do Paraná CDerall, da Comissão de Financiamento da Produção (CFP), do Instituto Brasileiro de Geografia e Estatistica (IBGES, da Empresa Brasileira de Assistencia e Extensão Rural (Emater), do Instituto de Economia Agricola de São Paulo (IEA/SP), da Fundação Getúlio Vargas CFGV e na ICI, que tambem forneceu os dados da evolução da area de plantio. os demais dados foram obtidos junto ao Iapar.

Para organização e manipulação dos dados, foram utilizados os softwares dBASE e SAS, que gerou as tabelas de lucros e custos comparativos. 
Na analise de dominancia estocástica utilizou-se o programa sugerido por ANDERSON et $\alpha$ li $(1977)$.

3.1.1. Caracteristicas do ensaio

o ensaio utilizado teve inicio em 1976. fruto de um convênio do Iapar com a ICI, e esta sendo desenvolvido na estação experimental do Iapar, em Londrina-PR. Teve como meta básica, a comparação da produtividade e rentabilidade (lucro) do sistema de plantio direto com o de plantio convencional, para diferentes sequencias de culturas de verão em rotação com o trigo, e a avaliação dos efeitos destes sistemas de produção sobre componentes do ecossistema solo/planta.

As caracter 1 sticas predominantes da area do ensaio, são:

- altitude: $566 \mathrm{~m}$;

- latitude: $23^{\circ} 23^{\prime} \mathrm{S}$;

- longitude: $51^{\circ} 11^{\prime} \mathrm{W}$;

- temperaturas anuais : máxima $24^{\circ} \mathrm{C}$; (dados de 12 anosj (janeiro) média $21^{\circ} \mathrm{C}$; minima $17^{\circ} \mathrm{C}$;

(junhol

- precipitações mensais: máxima $226 \mathrm{~mm}$; (dados de 12 anos) (janeiro) média $124 \mathrm{~mm}$; minima $56 \mathrm{~mm}$;

(agosto)

- precipitação média $1.615 \mathrm{~mm}$. arual: Coados de 1 e anoss 
Além disso, a área é sujeita a geada, com má distribuiçăo de chuvas no inverno. A tabela 5 mostra o comportamento das chuvas, no periodo de desenvolvimento do experimerito.

Tabela 5 - Precipitação ( mm média e maxima (24 hs), mensal e anual, em Londrina, de julho/76 a julho/88.

\begin{tabular}{|c|c|c|c|c|c|c|}
\hline \multirow{2}{*}{ Mss } & \multicolumn{2}{|c|}{ Chuva nos 12 anos } & \multirow{2}{*}{ Ano } & \multicolumn{3}{|c|}{ Chuva nos 12 meses } \\
\hline & Media & $\begin{array}{c}\text { Maxi ma rano } \\
\text { C:4 ms }\end{array}$ & & Media & \multicolumn{2}{|c|}{$\begin{array}{c}\text { Maxi ma/més } \\
\text { (24 h) }\end{array}$} \\
\hline Jameiro & 171.53 & $80,00-77$ & 1970 & 170,20 & 75,00 & out \\
\hline Fevereiro & 155,17 & $80,00 / 80$ & 1977 & 135,55 & 116,30 & $\mathrm{Abr}$ \\
\hline Março. & 152,88 & $66,00,83$ & 1978 & 115,67 & 81,40 & Nov \\
\hline Abr 11 & 119,88 & $151,20 / 84$ & 1979 & 105,25 & $B 2,00$ & Abr \\
\hline Maio & 128,52 & $61,40,79$ & 1980 & 176,88 & 80,00 & Fev \\
\hline Jumho & 94,38 & $102,00,82$ & 1981 & $1 己 6,17$ & 65,90 & out \\
\hline Jul ho & 56,15 & $75,00,78$ & 1982 & 152,33 & 102,00 & Jun \\
\hline Agosto & 51,65 & $62,50 / 86$ & 1983 & $177,5 \mathrm{e}$ & 74,80 & Jun \\
\hline Setembro & 114,04 & $61,20,83$ & 1984 & 103.83 & 151,20 & Abr \\
\hline Outubro & 137,18 & $75,00,76$ & 1985 & $96,1 \mathrm{z}$ & 98,20 & Abr \\
\hline Novembro & 170,79 & $83,20,87$ & 1986 & 116,46 & 62,50 & Ago \\
\hline \multirow[t]{2}{*}{ Dezembro } & 226,87 & $78,80,78$ & 1987 & 149,70 & 83,20 & Nov \\
\hline & & & 1988 & 165,05 & 83.00 & Mar \\
\hline
\end{tabular}

Fonte: Unidade metereológica da estação experimental do I apar em Londrina.

A partir destes dados, pudemos construir as figuras 1 e que mostram as curvas representativas da pluviosidade média mensal e anual dos 12 anos $e$ da máxima em 24 horas, na região do ensaio.

o solo e do tipo Latossolo Roxo distrófico, com alto teor de argila $(70 \%$ e baixa disponibilidade de 


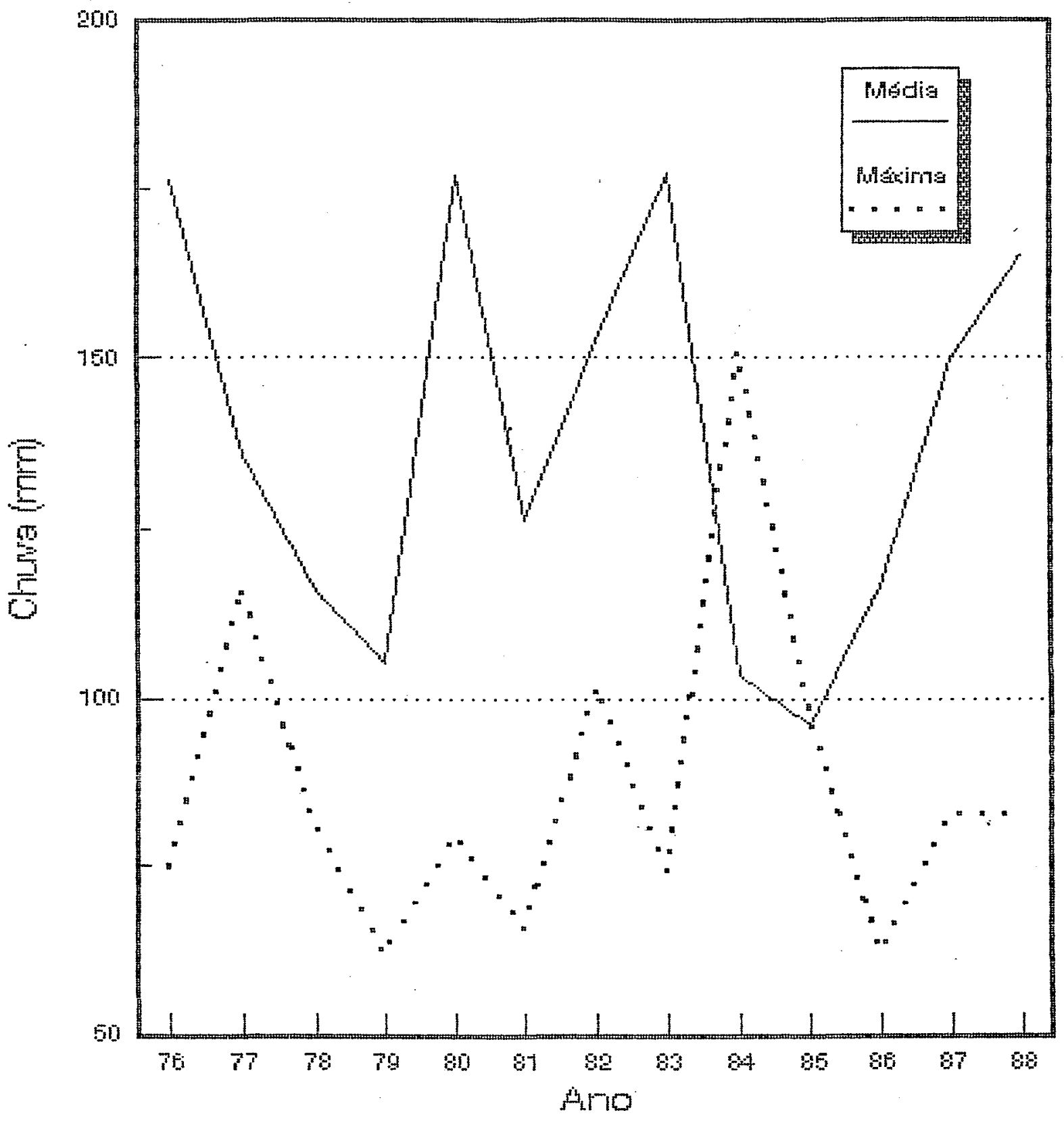

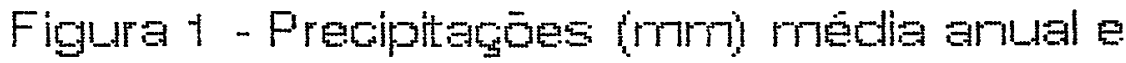
mexirna (24t) re قrea do probio. jLוtho $197 \mathrm{~B}$ a jultho 195 


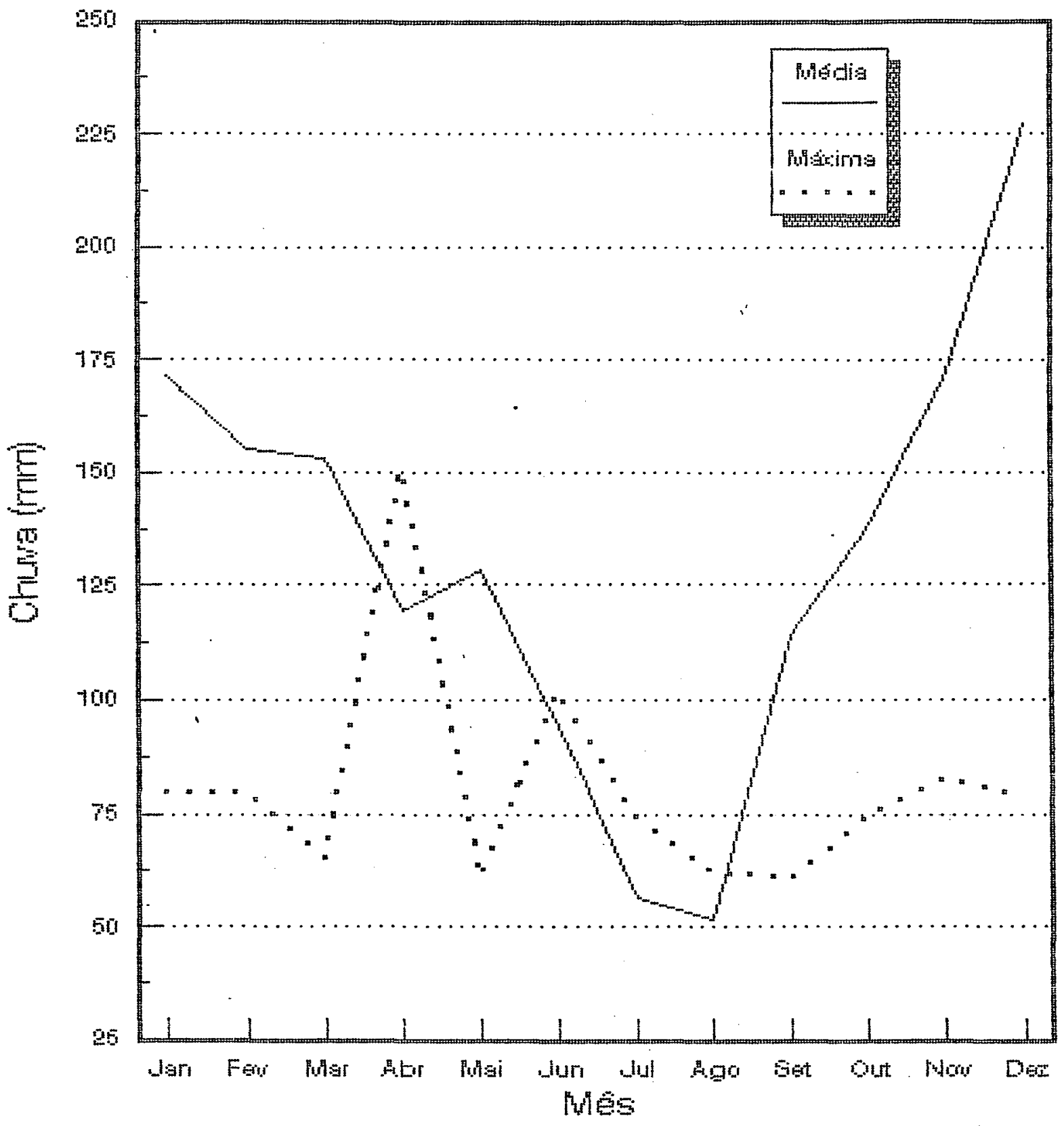

Figura 2 - Precipitaços (nnm) média mensal mexima (24ti) na area do ensaio. jutho $197 \mathrm{~g}$ a julto $19 \mathrm{ga}$ 
bases; a tabela 6 mostra suas caracteristicas químicas, na ocasião do ensaio.

Anteriormente, a area foi utilizada com pasto de gramineas, predominando o capim marmelada (Brackiaria plantaginea, (Link) Hitch) e o kikuio (Pennisetum clandestinum, Hocht e Chiov).

Tabela 6 - Análise química do solo, de amostras coletadas na camada arável $(0-20 \mathrm{~cm}$ por ocasião da escoIha da área do ensaio ( LRd).

\begin{tabular}{|c|c|c|c|c|c|c|c|}
\hline \multirow{2}{*}{$\begin{array}{c}\text { PH } \\
\text { Cem aguas }\end{array}$} & \multirow{2}{*}{$\frac{\text { Cations }}{A 1}$} & \multicolumn{2}{|c|}{ Trocáveis } & $($ meq $/ 10013$ & \multirow{2}{*}{$\begin{array}{l}A 1 \\
C \%\end{array}$} & \multirow{2}{*}{$\begin{array}{l}\text { M. } 0 . \\
C \%\end{array}$} & \multirow{2}{*}{$\begin{array}{c}P \\
C \%\end{array}$} \\
\hline & & $\mathrm{Ca}$ & $\mathrm{Mg}$ & $K$ & & & \\
\hline 5,0 & 0.1 & 5,0 & 1,3 & 0,52 & 1,6 & 2,3 & 1.5 \\
\hline
\end{tabular}

Fonte: MUZILLI, 1983.

Numa etapa anterior à instalação do ensaio Cinverno de 1976), foram efetuadas medidas para uniformização do terreno $C_{1}$ subsolagem a $40 \mathrm{~cm}, 1$ aração a $25 \mathrm{~cm}$ e duas gradagems niveladoras3. Após isto, o trigo foi plantado em área total, com aplicaça a 1 anço de $120 \mathrm{~kg}$ PzOs ha (termofosfato Yoorin) $e$ incorporação, na $2^{a}$ gr adagem ni vel adora.

Após a colneita do trigo, procedeu-se a:

- picagem e distribuiça da palha sobre o 
terreno, seguida de calagem $\mathrm{C} 3 \mathrm{t} / \mathrm{ha}$ de calcarip dolomitico);

- incorporação do calcario nas falxas de plantio convencional, através de aração e gradagens;

- nas faixas de plantio direto o calcario năo foi incorporado, permanecendo na superficie do terreno.

O del ineamento experimental fo de blocos ao acaso, com parcelas subdivididas, e 3 repetiçóes por tratamento. Cada parcela e constituida de $55 x 25 \mathrm{~m}$ a a subparcela, de 8X25 m. Foram consideradas útels as 4 fileiras cen trais das subparcelas, num total de $100 \mathrm{~m}^{2}$ cada. Nas parcelas, são comparados os sistemas de plantio e nas subparcelas, as sucessóes de culturas $c 7$ no totalj, representados na tabela 7 .

Tabela 7 - Suressao de culturas de yesa glilinalas an ensaio (1976/89).

\begin{tabular}{|c|c|c|c|c|c|c|c|c|c|c|c|c|}
\hline \multirow{2}{*}{$\begin{array}{l}\text { Trait } \\
\text { spato }\end{array}$} & \multicolumn{12}{|c|}{ A } \\
\hline & $76 / 77$ & 77178 & $78 / 79$ & $79 / 80$ & $80 / 81$ & $81 / 8 ?$ & $82 / 83$ & $83 / 84$ & $84 / 85$ & $85 / 86$ & $86 / 177$ & $87 / 88$ \\
\hline$A$ & 5 & 5 & 5 & 5 & $\$$ & $\$$ & 5 & $\$$ & s & 5 & 5 & s \\
\hline$B$ & $n$ & $n$ & $n$ & $n$ & 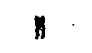 & $n$ & $B$ & $n$ & 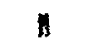 & 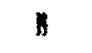 & B & $n$ \\
\hline c & A & $A$ & $A$ & $B$ & $A$ & $A$ & $A$ & $A$ & $A$ & A & $A$ & A \\
\hline 1 & 5 & $y$ & 5 & 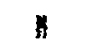 & 5 & $n$ & $s$ & 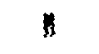 & s & $n$ & 5 & 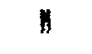 \\
\hline $\mathbf{E}$ & $A$ & 1 & $A$ & $n$ & A & 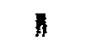 & $A$ & $n$ & $A$ & 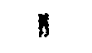 & 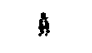 & $n$ \\
\hline F & 5 & $A$ & s & $A$ & s & A & 5 & $A$ & $s$ & $A$ & 5 & A \\
\hline 6 & $y$ & $\mathbf{5}$ & $A$ & \# & $n$ & $\mathbf{s}$ & $A$ & $n$ & $n$ & 5 & $B$ & $n$ \\
\hline
\end{tabular}


Observamos que os tratamentos $A, B$ e $C$ se referem às monoculturas de soja, milho e algodão, respectivamente. Em $D, \mathcal{E} E F$ estudamos as rotaçoses soja $X$ milho, algodão $X$ milho e soja $X$ algodão, por último. No tratamento G, soja, milho e algodão são postos em rotação. No inverno, a cultura plantada foi o trigo, todos os anos.

Os espaçamentos e as densidades de semeadura utilizados desde a implantaçă do experimento, tanto no sistema convencional quanto no direto, estão na tabela 8.

Tabela 8 - Espaçamento e densidade de semeadura utilizados no experimento. Londrina, safras $1976 / 1977$ a $1987 / 1988$.

\begin{tabular}{lcc}
\hline Cultura & $\begin{array}{c}\text { Espaçamento } \\
\text { (cm }\end{array}$ & $\begin{array}{c}\text { Densidade de } \\
\text { semeadura(kg/ha) }\end{array}$ \\
\hline Trigo & 17,5 & 150 \\
Soja & 50,0 & 90 \\
Milho & 100,0 & 20 \\
\hline
\end{tabular}

Fonte: Iapar, relatorio interno.

os cultivares utilizados variaram. Porém, dentro de um mesmo ano, foram os mesmos, nos dols sistemas de preparo do solo.

As equaçós de lucro 11 quido $C L L=R T-C C V$ + CFy3, ano a ano, for am montadas utilizando-se os preços dos insumos e produtos, nos meses de utilização e venda, 
respectivamente; os valores encontrados foram revertidos para valores em OTN.

\subsection{Metodos}

Para se proceder à escolha, levando em consideração o risco inerente à cada alternativa possivel, iremos recorrer a Teoria da Decisão. Esta teoria envolve as probabilidades subjetivas (pessoais) sobre a ocorrencia de eventos incertos, alem da avaliaço pessoal dos possiveis resultados. Reunindo-se ambos os aspectos, tem-se os criterios de escolha, que dependem das suposiços feitas sobre as opinižs pessoais e do conhecimento referente à essas probabilidades subjetivas (MOUTINHO, 1977 .

Serão estudados tress criterios de seleção para as alternativas de produção, a serem descritos neste item, que são:

1. Media-Variancia (Tobin -Markowitz);

2. Criterio de Simetria CHanoch-Levy3;

3. Dominaricia Estocástica CQuirk-Saposnick3.

O produtor rural, al tamente exposto ao risco em suas atividadesc BARNARD \& NIX, 1979; BISERRA, 1980; NORONHA, 1981; PERES, 1981), torna-se sensivel a ele. tomardo suas decisses dentro de limites de segurança subjetivos CPACHECO, 1987; MOUTINHO, 1977; BARNARD \& NIX, 1979). Um melhor nível de segurança para a formaçăo de suas 
oplniBes (probabilidades subjetivas) sobre os resultados ruturos, f alcançado atraves de informaç̧es disponiveis e da experiencia adquirida ao longo dos anos dentro da atividade agricola. E.deste modo que a experiencia passada serve como base de expectativas futuras.

Corsiderarido que a decisão do agricultor é estritamente pessoal e tendo em vista os riscos que ele percebe frequentemente, é fácil reconhecer que tenha objetivos bem diversos daquele indivíduo unicamente maximizador da renda CGARCIA \& CRUZ, 1979; BISERRA, 1985; PACHECO, 19852. Yários estudos comprovam que o agricultor não busca esta maximizaçăo da renda em primeiro plano, mas sim, baseia suas decisőes em criterios de maximização da utilidade esperada. Esta pode ser entendida, usando a definição de GARCIA \& CRUZ (1979), como sendo a enfase que - agricultor da aos criterios economicos e psicologicos. que estabelece suas preferencias com respeito à renda a ao risco. Naturalmente, existe, para cada individuo, um mapa de utilidade, refletindo a subjetividade dos criterios de decis ฐo.

FRIEDMAN \& SAVAGE (1948) estabeleceram tres nlvels de tomadores de decisão, conforme a propensão ou qrau de aversão ao risco. Assim, os individuos podem ser aversos. 1 ndiferentes ou propensos ao risco (fig. 3 . 

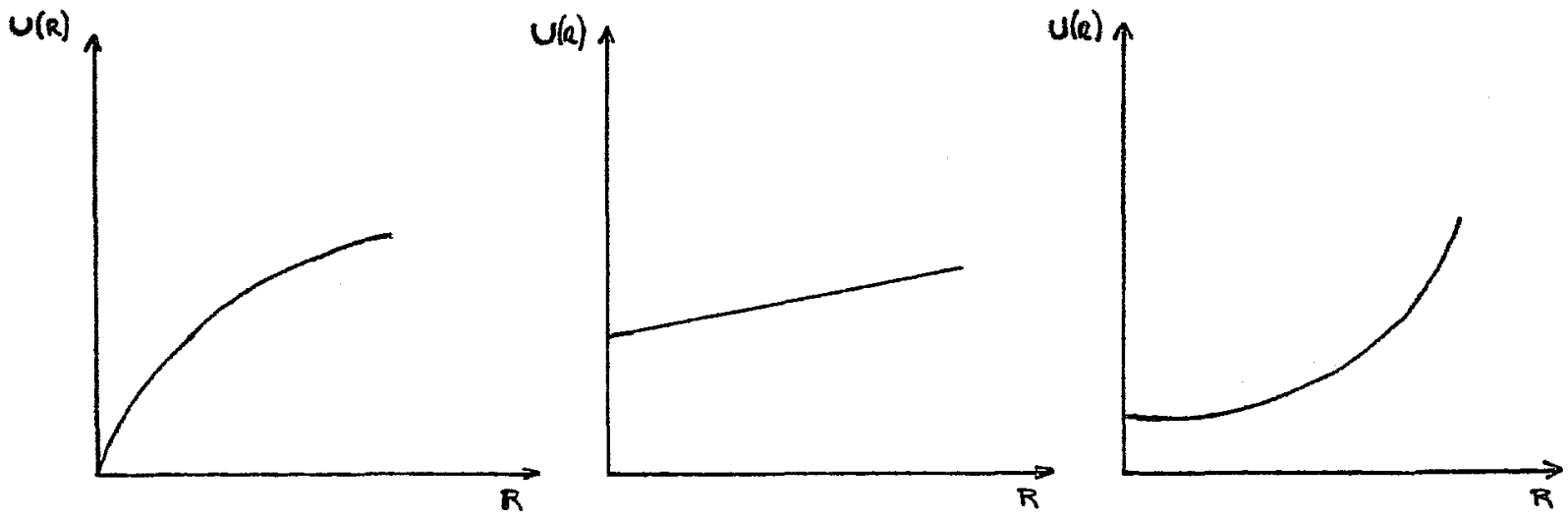

a) aversos

b) indiferentes

c) propensas

Figura 3 - Curvas de utilidade [UCRY] conforme a propensão ao risco: al aversos; bo indiferentes e cl propensos.

A ideia geral é que os agricultores são aversos ao risco, com a utilidade marginal de seus retornos [UMgCR]] positlva, porem, decrescente (íg. 3as. Parece. tambem, que os menores agricultores tendem a ser mais aversos ao risco. BARNARD \& NIX (1979) observaram que a propensão ao risco e mais frequente nos agricultores que detêm altos niveis de retorno e grande disponibilidade de capital. A conel usăo é de que predomins, na agricultura, a situação em que os agricultores so aceitam aumentos no nivel de riscos, se estes forem acompanhados de ganhos mais que proporcionais CDILLON, 1977b; BARNARD \& NIK, $1979 ;$ EI SERRA, 1985 ; etc. J. 


\subsubsection{Média-Variância (Tobin-Markowitz)}

Este método pressupõe que o individuo se baseia nas propriedades da função de probabilidade do retorno, para a escolha entre alternativas arriscadas. os parámetros relevantes desta funçă para a tomada de decisão, são o primeiro momento em relação à origem. ou seja, a média CE e o segundo momento em relação à média. que é a variância CV. E com este último que a noção de risco s incorporada.

Estes dois parametros são considerados suficientes por DILLON C1977a e ba, para se proceder a escolha entre alternativas, na maior parte dos problemas de decisão, e para a maioria dos tomadores de decisão. Ressalta que em aplicações empiricas ca partir de dados observados?, a simples aplicaça do criterio E-V podera produzir resultados adequados. Esclarece que, quanto mais elevado o momento, menor a sua influéncia na avaliação da utilidade do individuo.

Segundo BARNARD \& NIX (1979), a seleção de atividades numa fazenda é feita de forma a garantir um ganho médio minimo, a cada ano. Fara isto, o agricultor compa ra orau de desvio dos ganhos nas diferentes atividades. an relaģo a media de ganhos, o que pode ser aproximado pe1 a afirmação de que o agricultor decide baseado nos 
parâmetros da média e da vạriancia.

A questão não se levar em conta o terceiro momento da distribuição (assimetria). pressupźe que a probabilidade de ocorrerem eventos maiores ou menores que a média, a mesma, aspecto que tem recebido algumas criticas CGARCIA \& RUAS, 1981; PERES, 1981 J. Em outras palavras. tais afirmativas não refletem 0 fato de que diferentes distribuiçoses de probabilidades de retornos podem estar sendo representadas por um mesmo valor medio $6 f i g .42$. Um exemplo disto e caso de um agricultor de subsistência outro con maior flexibilidade de capital, com criterios. subjetivos de escolna (funçoses de utilidades distintos. Nestes casos, de ocorrencia bastante comum, ao ignorarmos a assimetria destas distribuifóes podemos incorrer em grave erro anal 1 tico.

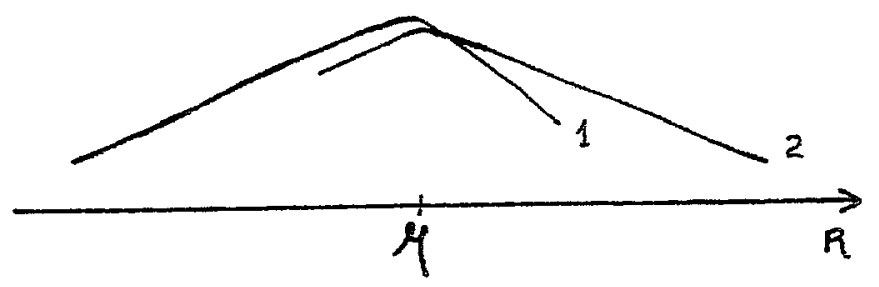

Figura 4 - Distribuiçôs de probabilidades de retornos 1 ? assimetrica ̀̀ esquerda e 2 assimetrica à direila, para 2 casos hipoteticos. 
Este metado tem duas pressuposiçōes básicas:

1. a função de utilidade do individuo deve ser quadratica, ou

2. os retornos das atividades consideradas devem apresentar distribuiçбes de probabilidade normais.

Pelo menos uma destas pressuposiçỡes deve ser atendida, para que o método seja válido como auxilio à tomada de decisão.

Sendo $\{x$ o conjunto dos possiveis resultados, a forma da função quadratica de utilidade pode ser:

$$
v(x)=b x+c x^{2}
$$

Considerando-se o objeti vo de maximização da utilidade, em condiçoes de risco, devem ser aplicadas as propriedades da esperança matemática, à UCX). Esta e também denominada valor médio, que é o valor em relação ao qual, a soma dos quadrados dos desvios é minima. Então.

$$
E[U(x)]=b E(x)+c E\left(x^{2}\right)
$$

A variancia é definada por:

$V(x)=E[x-E[x]]^{2}$

$v(x)=E\left[x^{2}-2 x E(x)+E(x)^{2}\right]$

$v(x)=E\left(x^{2}\right)-2 E(x) E(x)+E\left(x^{2}\right.$

$V(x)=E\left(x^{2}\right)-E(x)^{2}$ 
que, rearranjando, fica

$$
E\left(x^{2}\right)=E(x)^{2}+V(x)
$$

substituindo em (e) temos, finalmente,

$$
E[U(x)]=b E(x)+c\left[E(x)^{2}+V(x)\right]
$$

Em (8) vemos que, se o tomador de decisão tem função de utilidade de forma quadrática, ao maximizar a utilidade, ele relaciona suas preferências a média [EC $X]$ ] variancia $[V(x)]$ dos ganhos, que são os dois primeiros momentos da distribuição de probabilidade dos retornos.

$$
E|U(x)|=f|E(x) ; \quad V(x)|
$$

Neste estudo, vamos nos referir ao uso das formulas tradicionais para a determinaça destes dois parametros cmais indicado para o caso em que se tenha mais de 10 observaçöes . Como estaremos trabalhando com amostras e não com a população, usaremos as formulas dos estimadores não-tendenciosos, para a media e a variancia, descrito em HOFFMANN, C19805. Temos:

$$
\begin{aligned}
& E C \infty)=\frac{\sum x_{i}}{n}=\bar{x}, \text { para a média } \\
& V(x)=\frac{\sum C x_{i}-\bar{x}^{2}}{n-1}, \text { para a variancia }
\end{aligned}
$$

onde, no nosso caso, $x$ o lucro e $n$ o número de observaços (12 anos). 
A forma quadratica da funçăo de utilidade do tomador de decisão também e alvo de uma série de consideraçBes criticas. SAMUELSON (1970) diz que ela leva frequentemente a resultados discrepantes, tais como a redução absoluta e relativa do risco, à medida que os ganhos aumentam. Por em, ressalta que, nos casos em que o risco limitado, quer dizer, os niveis de risco assumidos em relação 20 patrimonio total săo pequenos, os resultados da aplicação do criterio $\mathrm{E}-\mathrm{V}$ săo bastante satisfatórios, em concordancia com DILLON (1977a) e TSIANG (1972). Mostra que, quardo o risco tende a zero, a forma quadrática fornece a sol ução exata para o problema de decisão.

DILLON C1977bs observa que, exceto no caso de uma função homogenea de $1^{\circ}$ grau, UCKL) $\neq$ KUCLJ, para qualquer constante não nula $K \neq 1$ e UCL $L_{1} L_{2}{ }^{3} \neq U C L_{1}{ }^{3}+$ UCL $L_{2}$, para quaisquer lucros năo nulos $L_{1}$ e $L_{2}$. Como consequencia destas propriedades, ao avaliar o risco utilizando-se uma funçăo de utilidade quadratica, não podemos nos basear na margem bruta CPYY - $\Sigma P_{i} X_{i} \rho$ e sim, na receita 12 quida CPyY - $2 P_{i} X_{i}-F 2$. Enfatiza esto aspecto dizendo que os custos fixos devem ser descontados. Esta observaça de Dillon e crucial. pois vários trabalhos na literatura. gue partem do principio que a função utilidade do tomador de decisão quadratica, analizam as melhores alternativas 
comparando a média e a variancia das margens brutas, ou seja, nåo descontam os custos fixos.

Verifica ainda que, a hipotese de função quadratica de utilidade implica na existéncia de uma região em seu dominio $(x)-b / 2 c)$, na qual o comportamento do individuo e irracional, por apresentar uma utilidade marginal negativa, para os resultados esperados.

Partindo de (1), vemos que, para o caso geral $(f i g .3 a)$, a utilidade marginal $U^{\circ}(x)=b+2 c x e$ positiva com $c<0$ e, supondo aversão ao risco, necessario que $U^{\prime}(X)=2 c<0$. As duas ultimas condiçbes implicam que $\mathrm{X} \in$ limitada no intervalo $\mathrm{X}<\mathrm{K}$, onde $\mathrm{K}=$ $-b / a c>0$. Alem disso, a última condição também mostra uma aversão crescente ao risco, independentemente da evolução do patrimorio pessoal do individuo, uma vez que a utilidade aumenta de forma decrescente, com a evolução dos ganhos.

Considerando-se a outra condif̧ăo do critério E-V, que diz respeito a forma normal da distribuiçá dos resultados, SAMUELSON (1970) lembra que são bastante raros os casos em que se aplica a lei do limite central. Segundo este teorema, a distribuif̧̃o das variaveis aleatorias $x_{2}$ tende a ser normal, à medida que cresce o número de observações (n). Formalizando, HOFFMANN (1980) se refere ao assunto, mostrardo que a distribuição limite de 


$$
z=\frac{\Sigma x_{i}-n \mu}{\sqrt{n} \cdot \sigma}=\frac{y-n \mu}{\gamma \overline{n \cdot \sigma^{2}}}
$$

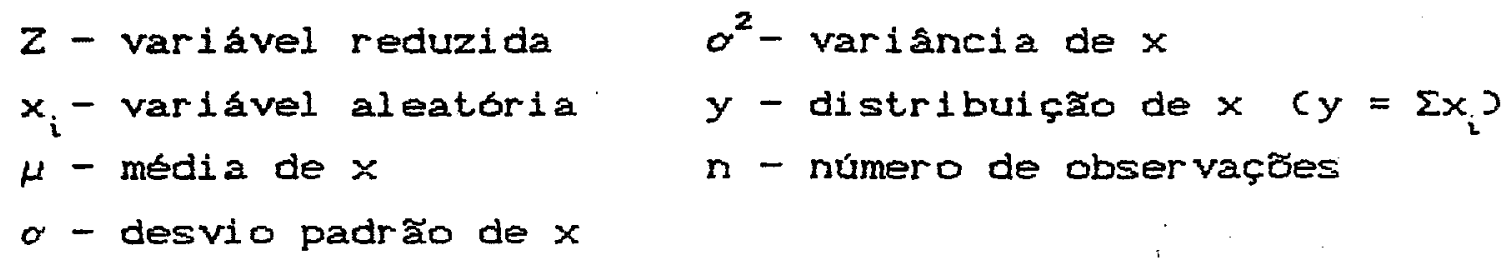

quando $n$ tende ao infinito, obedece a uma distribuição normal reduzida. Se a distribuiç̃o de $x$ não $E$ normal, ela se aproxima desta, a medida que $n$ cresce. Hoel. citado por HOFFMANN (1980), diz que geralmente consegue-se isto para $n \geq 50$. Provavel mente por isto. BISERRA (1980) lembra que para este criterio ser adotado com maior representatividade, no processo real de tomada de decisão. e necessário que o tamanho da amostra $(n)$ seja grande.

Para os casos em que a distribuiçăo de probabilidade dos retornos é normal, ANDERSON et aliz (1977) consideram que as alternativas selecionadas por este critério e pela Dominancia Estocástica ate o $e^{\circ}$ grau, são as mesmas. Sugere que a forma quadratica corresponde a uma aproximação, via série de Taylor, da verdadeira ce desconhecidal função de utilidade do tomador de decisão.

o comportamento tido como geral, e o de aversão ao risco, com utilidade marginal dos retornos 
positiva, porém decrescente. Tomando as derivadas parcials de (8), temos (PACHECO, 1985):

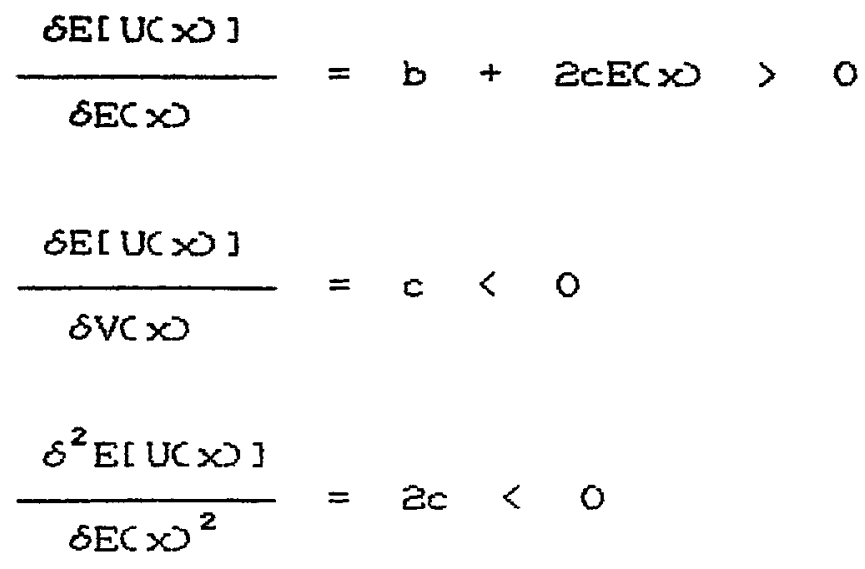

A utilidade marginal positiva e vista em (10); a aversão ao risco é garantida em (11) onde,para qualquer aumento no nivel de riscos [V(x), os retornos exigidos são mais que proporcionais. A última equaç̃o reflete a ação do risco como moderador das preferencias. impondo um limite na utilidade esperada, ou seja, mostra que a utilidade marginal e decrescente.

Para procedermos à escolha ertre duas alternativas arriscadas $C 1$ e 2 , necessário que, além dos maiores retornos, a alternativa escolnida seja aquela com menores niveis de risco. Quer dizer,

$$
E\left(x_{1}\right) \geq E\left(x_{2}\right) \quad E \quad V\left(x_{4}\right) \leq V\left(x_{2}\right)
$$


Caso isto nåo ocorra, as alternativas săo consideradas não comparáveis entre si. Portanto, fora destas condiç̧es, não e possivel decidir, segundo o criterio de Tobin-Markowitz. BISERRA (1985) se refere a este aspecto como desvantagem da aplicaçăo deste critério. que deixa a escolha a cargo do tomador de decisão, em função do seu grau de aversão ou propensão ao risco.

Visando solucionar este problema, Hanoch e Levy desenvolveram uma variaçăo deste criterio, onde es possivel se escolher entre alternativas, mesmo nos casos em que $E\left(x_{1}\right) \geq E\left(x_{2}\right)$ e também $V\left(x_{1}\right) \geq V\left(x_{2}\right)$.

Na verdade, podemos considerar uma alternativa adicional, que seria a de não se produzir, com expectativa de lucro e variancia nulas, muito comum na atividade agricola. Traçando-se a fronteira eficiente envolvendo-se esta alternativa, a escolha fica projudicada apenas se tivermos mais de uma alternativa dentro da fronteira eficiente.

3.2.2. Critério de Simetria (Hanoch e Levy)

E bastante similar ao criterio de Tobin-Markowitz (E-V) porém, com restrif̧ôs mals severas.

Baseia-se nos axiomas de Bernoulli e no Teorema de Utilidade Esperada. Assume que : 
1. a funçăo utilidade do tomador de decisão equadratica;

2. a forma da distribuição de probabllidade dos retornos simetrica cnormal, triangular, uniforme, beta, etc. 3 .

Esta última condição b bem memos restritiva do que aquela que limita a distribuição de probabilidade dos retornos a forma normal; a limitaçăo da forma quadrática da funçăo de utilidade, por sua vez, restringe a aplicabilidade do método, conforme criticas salientadas no item anterior.

Para que a tecnologia 1 domine a tecrologia 2. quando $E\left(x_{1}\right)>E\left(x_{2}\right)$ e $V\left(x_{1}\right)>V\left(x_{2}\right)$, onde $x_{i}$ são os retornos esperados, é necessário que a seguinte equação seja satisfeita:

$E\left[E\left(x_{1}\right)-E\left(x_{2}\right)\right] o x_{1}+\left[E\left(x_{1}\right)-E\left(x_{2}\right)\right]^{2}-\left[V\left(x_{1}\right)-V\left(x_{2}\right)\right]>0$

ou seja, o valor esperado do retorno do uso da tecrologia 1. tem que mais que compersar seu nivel de risco.

Estudando modelos de incorporação de risco na cultura de arroz irrigado, PÓRTO \& CRUZ (1962) encontraram maior poder de discriminação utilizando este metodo, do que aplicando o criterio de Tobin-Markowitz. talvez porque este seja um metodo mals restritivo. 
KUGIZAKI (1982) propóe um modelo simplificado de obtenção da media $(E)$ e variáncia (V), para comparação de alternativas, segundo o criterio de seleção de Hanoch e Levy.

Não utilizaremos este método, por considerarmos que a forma quadratica da função de utilidade não traduz as reais condiçós do processo de decisão dos indi víduos.

\subsubsection{Dominancia Estocastica (Quirk-Saposnik)}

E um instrumento metodalogico que considera algumas caracteristicas de decisão preconizadas pela função utilidade quadrática, onde o individuo prefere sempre maior retorno e a averso ao risco. A diferença, e principal vanta gem, da utilização deste criterio, reside no fato de que não precisamos conhecer a forma das funçóes utilidade dos individuos, uma vez que tem pressuposiçoses simples e gerais sobre a maneira como estão distribuidos os resultados das ạ̧ס̃S. CMOUTINHO, 1977; DILLON, 1977b; GARGIA \& CRUZ, 1979; PACHECO, 19853

Baseia-se na comparação entre as distribuiçoses cumulativas de probabilidade dos retornos, que estáo associadas as diferentes alternativas em questão. Em outras palavras, considera a distribuição total dos 
resultados, ao inves de apenas os dols primeiros momentos da distribui ção.

Dentro deste criterio, verifica-se trés condi çBes:

1. a função ut1lidade esperada $E[U(x)]$, deve apresentar utilidade marginal dos retornos positiva $\frac{\mathcal{E U}}{\mathcal{E R}}>0$; 2. estes retornos marginais deverăo ser decrescentes $\frac{\delta^{2} U}{\delta R^{2}}<0$;

3. a propensão marginal de incorrer em risco aumenta com a riqueza $\frac{\delta^{2} U}{\delta R^{3}}>0$.

As caracteristicas 1 e são identicas à pressupostas pela função de utilidade quadratica e definem o primeiro e o segundo grau de Dominancia Estocástica CPGD e SGD - PACHECO, 1985D. A terceira caracteristica se refere ao terceiro grau de Dominancia Estocastica (TGD).

Na figura 5 a seguir, exemplificamos este
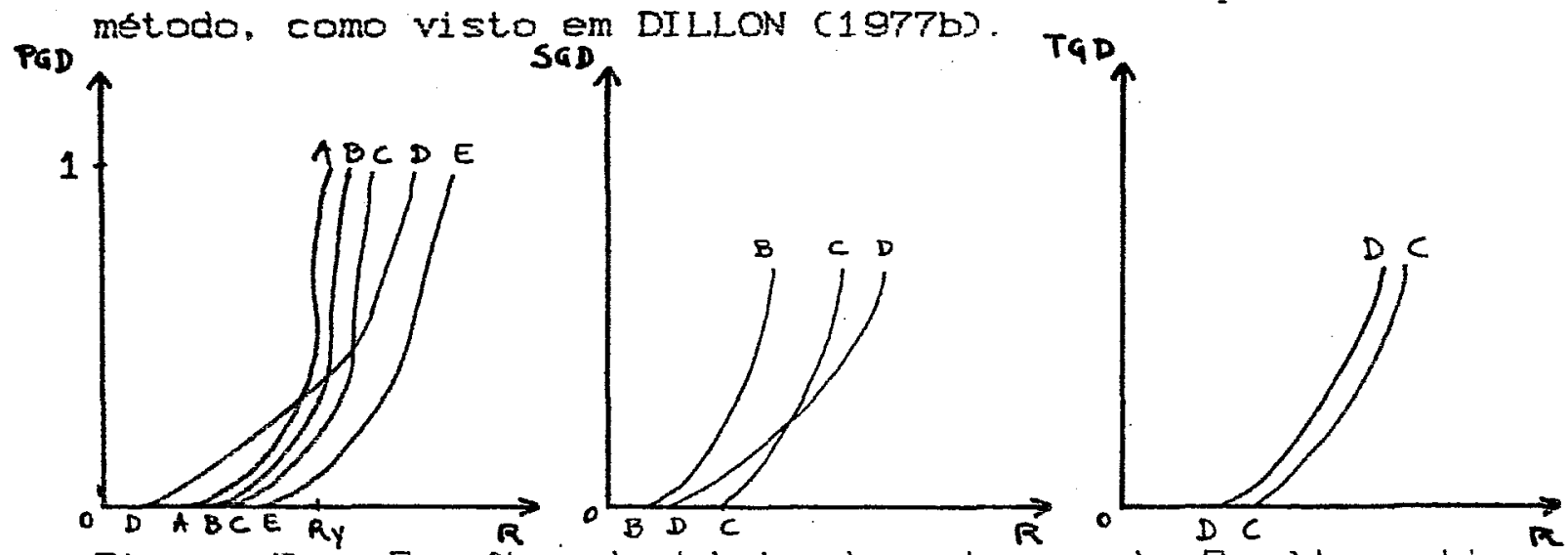

Figura 5 - Funfóes desidade de retorno de 5 alternativas arriscadas, para o a) PGD; b) SGD e c) TGD 
Neste caso, a alternativa $E \Leftrightarrow$ a preferida por aqueles individuos que preferem maiores lucros, pois para um determinado $n i v e l$ de retorno $(R y)$, a a que oferece menor probabilidade do nivel de retorno ocorrido cair abaixo daquele estipulado inicialmente CRy. Entre as outras, não podemos decidir imediatamente, uma vez que elas se cruzam. Isto significa que cada uma delas apresenta melhores resultados até um determinado nivel de retorno, a partir do qual outra alternativa passa a ser mais interessante.

E necessario recorrer a maiores graus de dominancia estocastica, para que se possa proceder a escolha. Assim, no SGD, $B$ eliminada, restando $C$ e $D$. Submetendo-as ao TGD, vemos que $C$ domina $D$.

No PGD, as escolhas refletem as atitudes dos individuos que procuram maximizar a utilidade esperada, sem se preocuparem com o risco. Neste grupo estão os individuos aversos. indiferentes e propensos a risco. NO SGD. imprem-se uma restriça adicional, em que a utilidade marginal do retorno é positiva e decrescente, com uma curva de função utilidade concava ccaso dos individuos aversos ao risco). O TGD envolve os individuos que se tornam menos aversos ao risco, com o aumento da riqueza (DILLON, $1977 \mathrm{~b}$ ).

E interessante notar que estes tres graus de 
dominancia se referem a aspectos relativos a parte inferior das caudas das distribuiçóes. E necessário que a alternativa dominante tenha retorno e limite inferior da distribuição cumulativa das probabilidades, mais elevados que as alternativas dominadas. Isto nem sempre ocorre nestas regióes, e constitui uma limitação do metodo (PACHECO, 1985; MOUTINHO, 1977 .

Os critérios de domináncia estocástica podem ser empregados com variaveis discretas ou continuas, atraves de fórmulas especificas para cada caso. As alternativas podem ser ações, planos ou tecnologias, e são representadas por uma úmica variavel $x$ coliscreta ou continuas, aqui definida pela receita liquida.

Vamos considerar o caso da variável discreta, que o que será utilizado nesta pesquisa.

A definição formal dos tres graus de dominancia, para a variável discreta, é:

$$
\begin{array}{ll}
F_{1}(R)=\sum_{i=1}^{n} f\left(x_{i}\right) & a \leq R \leq b \\
F_{2}(R)=\sum_{i=2}^{n} F_{1}\left(x_{i-1}\right) \cdot \Delta x_{i} & a \leq R \leq b \\
F_{g}(R)=\frac{1}{2} \sum_{i=2}^{n}\left[F_{2}\left(x_{i}\right)+F_{2}\left(x_{i-1}\right)\right] \cdot \Delta x_{i} & a \leq R \leq b
\end{array}
$$


onde $f\left(x_{i}\right) \Leftarrow$ a função distribul făo de probabilidade de $x$. definida no intervalo $[a, b] ; R$ qualquer valor para este intervalo; $\Delta x_{i}=x_{i}-x_{i-1}$ são os acrescimos; $F_{1}(R), F_{2}(R)$ e $F_{9}(R)$ são valores que podem ser obtidos diretamente das curvas de probabilidade acumuladas do $1^{\circ}, 2^{\circ}$ e $3^{\circ}$ graus de domináncia estocastica, e são designadas funçós de distribuiça cumulativa CFDCS da alternativa $F$.

Considerando-se uma outra alternativa, $G$, e procedendo-se aos mesmos calculos, dizemos que a alternativa $F$ domina ce melhors que $G$ para cada grau de dominancia estocástica, se $F_{1}(R) \leq G_{1}(R), F_{2}(R) \leq G_{2}(R)$, e $F_{3}(R) \leq G_{3}(R)$, para $R$ no intervalo $[a, b]$, respectivamente no $1^{\circ}$. $e^{\circ}$ e $3^{\circ}$ grau de dominancia, para ao menos um valor da desigualdade. Graficamente, isto significa que a curva associada à alternativa dominarte estara sempre à direlta da curva associada à alternativa dominada (fig. 5 ).

A maior limitação deste metodo, diz respeito a necessidade de profunda especiflcaçăo das distribuiços de probabilidade dos resultados das diferentes alternativas envolvidas, além do que, há perda da generalidade ao não se impor restrifbes, a meros que, as distribuiḉ̧s de proba bilidade subjetivas dos agricultores a quem se dirige o estudo, sejam idénticas aquel as utilizadas na avaliaça de 
risco-eficiencia CDILLON, 1977b; PACHECO, 1985; GARCIA \& CRUZ, 19793

PACHECO (1985) encontrou o mesmo poder de diserimi nação C30\%, utilizando o eriterio de Hanoch e Levy e $2^{\circ}$ grau de Domináncia Estocástica, na avaliaçăo de um experimento agricola. Justifica dizendo que, neste caso, o aumento no risco foi sempre multo mais que proporcional ao aumento do retorno esperado. Neste estudo, as alternativas selecionadas foram muito distintas entre si, dificultardo a recomendaça definitiva aos agricultores. Obteve um malor rigor na seleção, quando trabalhou com a Dominancia Estocástica com respeito à uma funçăo $1100 \%$ de discriminação, com apenas uma alternativa selecionada. Com base nos resul tados encontrados, recomenda o emprego do criterio de Hanoch-Levy, ao inves da Dominancia Estocástica, por ser de aplicação muito mais simples.

Contrariamente, MOUTINHO (1977) recomenda que se continue empregando a D.E., devido à dificuldade em se conhecer as preferticias individuals dos agricultores. Em seu trabalho, encontrou um poder de discriminaçăo considerado muito baixo para o setor agricola (16.7\%). Apoiando-se em ANDERSON et alii (1977). ela explica que isto se dá devido à excessiva importancia atribuida as extremidades das distribuiçzes que estro sendo comparadas. 
No trabalho de GARCIA \& CRUZ (1979) esta técnica se mostrou eficiente na reduçăo do número de alternativas disponiveis, concentrando os resultados naquelas com maiores condiçoses de satisfazerem os agricultores aversos ao risco. Mesmo assim, em alguns casos, o grupo de altermativas selecionadas ainda era extenso, dificultando uma recomendaçăo mais precisa.

Em outro trabalho usando esta metodologia CGARCIA \& RUAS, 1981J, o impasse final entre duas alternativas selecionadas, deveu-se a uma questão de grau de aversăo ao risco.

FORTO \& CRUZ (1982) citam que, segundo Porter. para dados não agregados, o criterio E-V terde a apresentar maior poder de discriminaçăo das alternativas. já que o mais restritivo em suas hipóteses. 


\section{RESULTADOS E DISCUSSÃO}

\section{1. Comparacão entre Plantio Direto e Convencional}

Apos submeter os dados aos métodos deseritos no capitulo 3 e com base nos resultados alcançados, procuramos traçar paralelos entre estes dois sistemas de plantio, conforme criterios destacados a seguir.

\subsubsection{Aspectos fisicos}

Passamos a análise dos resultados físicos da produção, por rotaçăo e cultura, ressaltando que, sobre este aspecto, outros estudos devem ser efetuados, a fim de se compreender melhor os fatores que interagiram para obtenção destes valores.

Como medida de comparaçăo, baseamo-nos na receita bruta, que - o produto do preço da mercadoria (soja, trigo ou milho) pela quantidade. Sendo que o preço de venda independe do sistema de plantio, a variação da receita bruta deve-se apenas às diferenças nas quantidades produzidas, que e o que nos interessa comparar. 


\subsubsection{Por rotação}

Constatou-se que o plantio direto superou o corvencional, para qualquer rotação estudada, em todos os periodos, conforme traduzimos da tabela 9.

A rotação $D$ apresentou sempre os melhores resultados em todas as fases do estudo cexceto na fase II. no plantio convencionals, com destaque no plantio direto. que proporcionou adicionais de $15 \%$ a $25 \%$ nas quantidades de grăos produzidas, comparados aos resultados do sistema convencional nas demais rotaçóes. Alem disso, teve a maior variação na receita (Pd.PC), que mede a vantagem comparativa do plantio direto, revelando maior sensibilidade quanto ao sistema de plantio adotado.

Na rotação $B$, com apenas as gramineas em sucessão, obteve-se a menor vantagem comparativa, exceto para o periodo I. Ainda assim, as produtividades apresentadas por esta rotaçăo foram superiores as da rotaçăo A (soja $X$ milho) nos dols metodos de plantio, contradizendo o que se espera em termos de leguminosas e gramineas em sucesริั0. 
Tabela 9 - Receita bruta (OTN/ha) e variação percentual entre os sistemas (Pd/PC3, por periodo e total, conforme a rotação - 1976/1977 a $1987 / 1988$.

\section{Rotação}

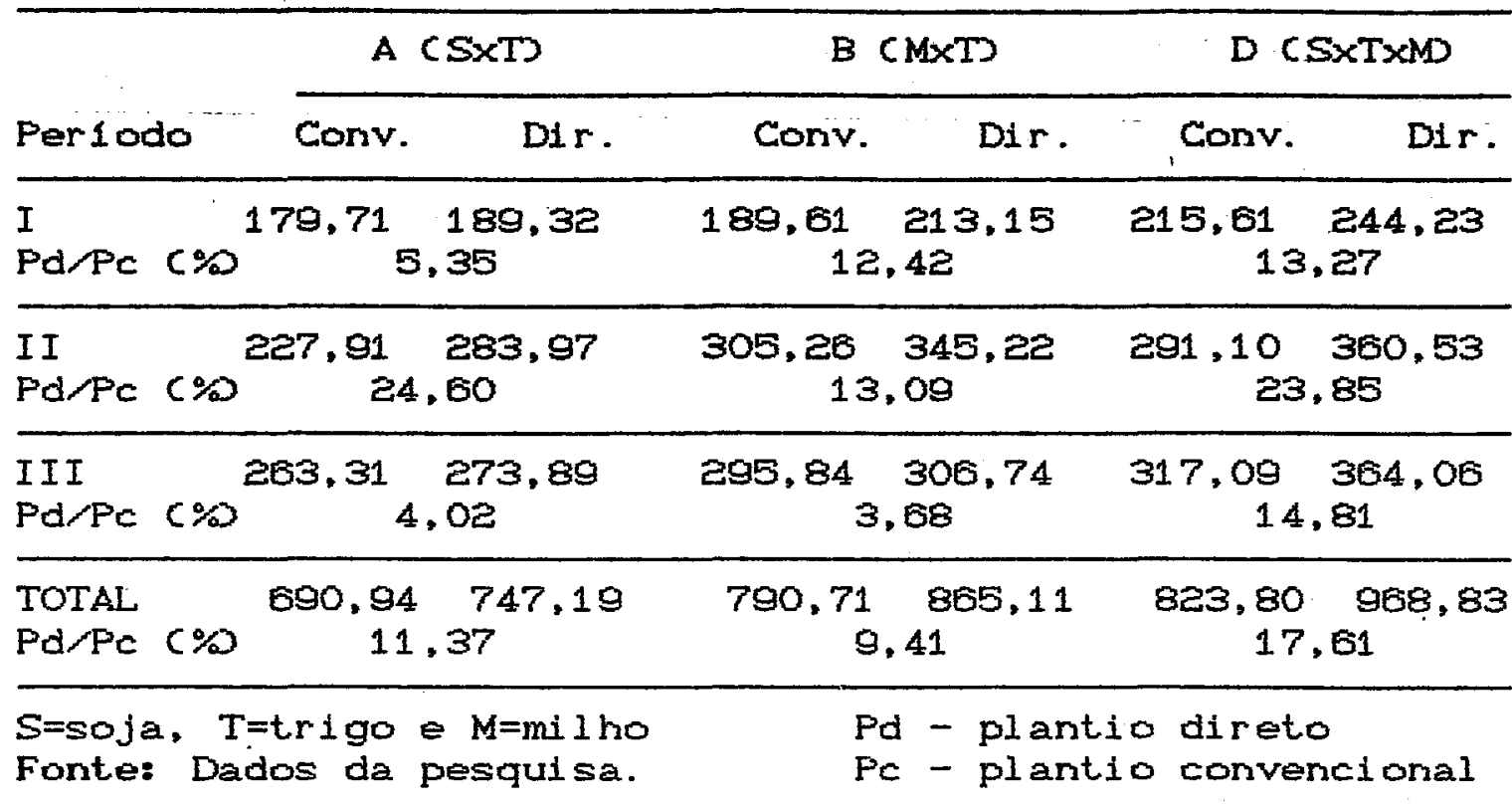

\subsubsection{Por cultura}

\section{1.1.2.1. Milho}

Esta cultura esteve preserte sob duas rotaçס̃es, $B \in$ D. Em ambas, o plantio direto proporcionou maiores medias de produtividades, no total do periodo ana1 isado, com acrescimos de $2,71 \%$ e $13,52 \%$, respectivamente, mostrando maior impacto, quanto ao sistema de plantio adotado, na rotação D capendice 1). Esta rotação propiciou as melhores colheitas de milho, $30,96 \%$ maiores quando em plantio direto. 
No plantio convencional. o desempenho do milho na rotação $D$ foi superior em $15,36 \%$, ao passo que, no plantio direto, esta diferença passou a $27.50 \%$.

O comportamento das produtividades variou em ambos os sistemas de plantio, com um incremento do $1^{\circ}$ para - $e^{\circ}$ periodo e uma queda na fase seguinte. Ao ifirial, registrou-se uma reduçăo nas produtividades, do $1^{\circ}$ para $03^{\circ}$ periodo, menos acentuada no plantio direto $e$ entre as rotaçớes, na D, conforme mostramos na tabela 10.

Tabela 10 - Variação percentual entre os períodos, nas produtividades do milho, por rotação e sistema de plantio - $1976 / 1977$ a $1987 / 1988$.

\begin{tabular}{ccccc}
\hline & \multicolumn{3}{c}{ Rotação } \\
\cline { 2 - 5 } Periodo & Conv. & Dir. & & \multicolumn{2}{c}{ D CSxTxMD } \\
\hline $1^{\circ}$ ao $2^{\circ}$ & 5,89 & 12,64 & 21,57 & 10,31 \\
\hline $2^{\circ}$ ao $3^{\circ}$ & $-21,59$ & $-16,39$ & $-24,12$ & $-11,47$ \\
\hline $1^{\circ}$ ao $3^{\circ}$ & $-16,97$ & $-5,82$ & $-7,76$ & $-2,35$ \\
\hline
\end{tabular}

$S=s o j a, T=t r i g o e M=m i l h o$

Fonte: Dados da pesquisa

Varios fatores podem estar contribuindo para isto, entre eles a queda de produtividade pelo empobrecimento do solo, no plantio convencional, e pela compactação. no plantio direto. 
Cabe ressaltar que, a safra de $1985 / 86$ foi particularmente prejudicial ao desenvolvimento do milho. devido ao deficit hidrico ocorrido nos meses de outubro (germinaçáo) e dezembro (floração). Neste ano agricola, o plantio direto mostrou-se bastante vantajoso, proporcionando produtividade $19,59 \%$ superior na rotação $B=38 \%$ na rotação $D$, indices destacadamente mais elevados que os demais, levantados ao longo dos 12 anos de comparacão.

E importante notar que, a continuidade do plantio de milho apos o trigo fol prejudicial ao milho, notadamente no plantio direto que, ainda assim, apresentou produtividades ligeiramente superiores ao convencional. Com a introdução da soja na rotação, o nivel de resposta do milho sofreu sensivel melhora, coincidindo com os resultados encontrados por DANIEL C19813. Varios pesquisadores (KINJO, 1978; BAKAJEV, 1981; KONDORFER, 1984 ) atribuem a isto uma deficiência acentuada de nitrogênio, cuja dinâmica 6 muito bem descrita por MUZILLI Cin: IAPAR, 19815.

\subsection{Soja}

os resultados se referem às rotaçōes A Csoja $X$ trigo) e D Csoja X trigo. $X$ milho e estão no anexo 2. Segundo relatório interno do Iapar, esta cultura destacou-se como uma das mais beneficiadas pelo plantio 
direto, nos processos de germinação e emergencia, bem como,

no desenvolvimento das plantas. Tal como encontrado por SIDIRAS ( 1983 ) E KEMPER \& DERPSCH (1981).

Contrariando a expectativa, o plantio direto mostrousse vantajoso $10 g 0$ nos dois primeiros anos, invertendo-se a situaça no bienio seguinte. Observe-se. que, as duas primeiras safras se caracterizaram por falta de chuvas, evidenciando a melhor performance do plantio direto em anos de restriçăo hidrica, confirmando os resultados de vários estudos CVIEIRA, 1984; BAKAJEV, 1981; SIDIRAS, 1984; ORTOLANI, 1977; MUZZILI, 1983; JONES, 1988 . Para se ter uma idtia, 1977 foi $0 \Xi^{\circ}$ ano mais seco, em $1 \mathrm{z}$ anos, no mês de outubro, fase critica para a soja Germinação). Nesta safra, o plantio direto produziu $173,21 \%$ a mais de soja do que o convencional Crotação As. Na safra de 1985/86, também com pouca chuva em outubro $e$ dezembro (rloração, somado à ocorrencia de saraiva em novembro e dezembro, o plantio direto saiu-se melhor, com vantagem de ate $23,74 \%$ sobre o plantio convencional Crotaçäo A.

For outro lado, nas duas safras seguintes, com chuvas normais e bem distribuidas, o plantio convencional apresentou suas unicas vantagens em relaçao ao direto, em todo o periodo analisado. O relatorio do Iapar 
acusa, nestas ocasiōes, um retardamento na maturação

ecolheita no plantio direto, trazendo prejuízos na qualidade e quantidade da soja produzida.

$02^{\circ}$ periodo da aralise $45^{\circ}$ ao $8^{\circ}$ ano foi marcado por destacados beneficios proporcionados pelo plantio direto. Porém, no periodo seguinte, houve decréscimo na produtividade, ainda que mantida a vantagem sobre o plantio convencional.

A cultura da soja parece ser bastante sensivel à compactaça do solo, que deve ter se acentuado no último período, prejudicando, especialmente, o desempenho do plantio direto.

O saldo dos 12 anos foi favoravel ao plantio direto, em $9 \%$ na rotaçăo A e $20 \%$ na D. A soja se beneficiou pela manutenção das 3 culturas em rotação tal como ja vimos para o milho, com a produtividade $34,44 \%$ superior quando se adotou o plantio direto, em relaça ao plantio converacional sob rotaçăo A.

Observando a tabela 11 e apendice 2 , vemos que, no sistema convencional de plantio, a produtividade do 1 - para o $z^{\circ}$ perído caiu para ambas as rotaços e sofreu um pequeno acréscimo $\left(0,79 \%\right.$ na $A \Leftrightarrow 6,59 \%$ na d) no $3^{\circ}$ período. No entanto, a diminuição da produtividade foi maior que o acrescimo, resultando numa menor produçăo por 
área do $1^{\circ}$ para o $3^{\circ}$ periodo. de forma mais drástica na

rotaç̃o $D$ C-Z7,51\% que na A $\quad-12,60 \%$. Apesar desta tendsmcia, fol ainda a rotação $D$ a que ofereceu maior vantagem $(8,56 \%$ em termos de produtividade, nos 12 anos.

Tabela 11 - Variaçäo percentual nas produtividades da soja, por rotaça e sistema de plantio, entre os periodos.

\begin{tabular}{|c|c|c|c|c|}
\hline \multicolumn{5}{|c|}{ Rotação } \\
\hline \multirow[b]{2}{*}{ Periodo } & \multicolumn{2}{|c|}{$A C S \times T)$} & \multicolumn{2}{|c|}{$D(S \times T \times M)$} \\
\hline & Conv. & Dir. & Conv. & Dir. \\
\hline $1^{\circ}$ a0 $2^{\circ}$ & -13.29 & 14,34 & -32.00 & 6.61 \\
\hline $2^{\circ}$ ao $3^{\circ}$ & 0.79 & -17.63 & 6.59 & $-20,65$ \\
\hline $1^{\circ} 203^{\circ}$ & $-12,50$ & 5,82 & -27.51 & $-15,41$ \\
\hline
\end{tabular}

$S=s o j a, \quad T=i r i g o \in M=m i l h o$

Fonte: Dados da pesquisa

Numa tendencia contraria ao convencional, 0 plantio direto registrou acréscimo na produção do 1 para o $Z^{\circ}$ periodo e decrescimo, na etapa seguinte. Também neste sistema, a rotação $D$ apresentou maior redução no nivel de produtividade, ao 1 ongo de 12 amos $(-15,41 \%$.

Se voltarmos o enfoque para o comportamento das produtividades dentro de cada rotacăo vemos que, en ambas, a queda de produtividade do $1^{\circ}$ para $03^{\circ}$ periodo foi cerca de duas vezes maior no plantio convencional.

Constata-se, finalmente, que na ultima fiase 
desta amalise, as produtividades foram inferiores aos

primeiros anos, em qualquer alternativa apresentada, tal como ocorrido com o milino. Partindo-se da mesma justificativa usada no caso do milho. E importante ressaltar que, o possivel efeito da perda da fertilidade foi pior que o da compactação. pois o plantio direto ainda proporcionou produtividades superiores, na media dos 12 anos, em $8,56 \%$ para a rotação A e $19,89 \%$ para a D. Ademais, a compactaça pode ser eliminada atraves de tecricas simples, ao passo que, o solo que foi perdido rão pode ser reposto.

\subsection{Trigo}

Destaca-se a grande vantagem inicial do plantio direto nas safras 1976,77 e $1977 / 78$ C58.79\% a 301,58\%, marcadas por chuvas escassas e mal distribuidas. Apesar do melhor desempenho do plantio convencional nos dois anos seguintes $43,78 \%$ a $53,58 \%$ de desvantagem, foi o plantio direto que proporcionou as maiores produtividades para o trigo, em todos os periodos do estudo, nas 3 rotaçoses consideradas. A excessão foi para a rotaçăo $B$ no ultimo periodo, com saldo $5,7 \%$ maior no plantio convencional Capendice 32.

A curva de produtividade do plantio direto sofreu uma queda durante $01^{\circ}$ periodo e elevou-se no $z^{\circ}$ 
periodo. para novamente decrescer no no último periodo.

Este comportamento reforça a idéa de que os beneficios do plantio direto se fazem sentir no medio e longo prazos. desde que adotadas tecricas que evitem a compactação.

As safras de $1981 / 82$ e $1986 / 87$ apresentaram melhores resultados para o plantio convencional, em todas as alternativas. No $1^{\circ}$ caso nå houve ocorrencia de problemas climaticos, podendo, entre outras razbes, ter havido pouca cobertura no plantio direto. No $e^{\circ}$ caso, a explicaçáo talvez esteja na compactaça do solos além do que, a ocorrencia de chuvas normais e bem distribuidas, não constitui fator de limitaçăo a produçăo, sob plantio convencioral. Contrariamente, num ano como $1983 / 84$, em que a pluviosidade no més de agosto (final de maturaçáo foi de $0 \mathrm{~mm}$, a vartagem do plantio direto atingiu niveis de $69 \%, 63 \%$ e $98 \%$ para as rotaç̃es $A, B$ E $D$, reforçando a importancia deste sistema nos casos de riscos climáticos.

Em abril de 1984 , quando o cereal nåo havia completado sequer 30 dias de plantado, ocorreu a maxima chuva em 24 horas, dos 12 anos do estudo. Meste ano, as produtividades do trigo foram superiores, no plantio direto, em todas as rotaçóes $C 31 \%$ na $A, 7 \%$ na $B$ e $24 \%$ na D) indicando a importância da cobertura vegetal para a proteção do solo. Outros anos de chuvas erosivas, na época 
do plantiorgermi nação do trigo, foram : 1977, $1982,1983 \in$

1985, todos com vantagem para o plantio direto, sendo que a safra de $1985 / 86$ foi perdida, devido à seca.

os indices de vantagem do plantio direto sobre o convencional. para as rotaçర̃es A, B e D nos 12 anos, foram $17,93 \%, 31,64 \%$ e $23,29 \%$, respectivamente.

A sucessão das duas gramineas foi prejudicial ao trigo, que se beneficiou pela substituição do milho pela soja. No entarto, a melhor opção para o rendimento do trigo, tal cono se constatou para o milho e para a soja, foi a rotaça com as 3 culturas. E interessante observar que o efeito nocivo da rotaçăo milho $X$ trigo. quando comparada com soja $X$ trigo, foi cerca de 4 vezes menor no plantio direto, como nos mostra a relafão A/B da tabela 12.

Tabela 12 - Vantagens relativas $6 \%$ das produtividades do trigo, entre as rotaçoses os sistemas de plantio.

\begin{tabular}{lccc}
\hline $\begin{array}{c}\text { Sistema } \\
\text { de } \\
\text { Plantio }\end{array}$ & A,E & Rotaç̃os & \\
\cline { 2 - 4 } & 15,64 & $\mathrm{D} / \mathrm{A}$ & $\mathrm{D} / \mathrm{E}$ \\
\hline Convenc & 3,59 & 2,28 & 18,27 \\
Direto & 6,93 & 10,77 \\
\hline
\end{tabular}

$A=\operatorname{rotaça~} A, B=\operatorname{rotação~} B \in D=$ rotaçăo $D$

Fonte: Dados da pesquisa

De modo geral, as produtividades do trigo 
aumentaram ao longo dos 12 anos, mais acentuadamente no

plantio convencional e. com menos destaque, na rotação $B$, conforme vemos na tabela 13.

Tabela 13 - Variação percentual nas produtividades do trigo. por rotação e sistema de plantio, entre os períodos.

Rotaçăo

\begin{tabular}{|c|c|c|c|c|c|c|}
\hline \multirow[b]{3}{*}{ Per íodo } & \multicolumn{6}{|c|}{ Rotaçăo } \\
\hline & \multicolumn{2}{|c|}{$A(S \times T)$} & \multicolumn{2}{|c|}{$\mathrm{BC}(\mathrm{M} \times \mathrm{T})$} & \multicolumn{2}{|c|}{$D(S \times T \times M)$} \\
\hline & Conv. & Dir. & Conv. & Dir. & Conv. & Dir. \\
\hline $1^{\circ}$ ao $z^{\circ}$ & $-23,90$ & $-23,60$ & $-41,20$ & $-34,54$ & $-28,20$ & $-23,33$ \\
\hline$z^{\circ}$ ao $3^{\circ}$ & 38,41 & 83,74 & 170,94 & 59,74 & 138,47 & 86,44 \\
\hline $1^{2}$ ao $3^{\circ}$ & 128,84 & 40,37 & 59,32 & 4.57 & 68,84 & 42,95 \\
\hline
\end{tabular}

S=soja, $T=t r i g o$ e $M=m i l h o$

Fonte: Dados da pesquisa

\subsubsection{Aspectos económicos}

\subsubsection{Lucros}

O resultado, em termos de lucro liquido. é apresentado no aperidice 4.

A rotação A foi prejudicial em ambos os sistemas de plantio, sendo que os prejuizos, em plantio direto, foram $60.29 \%$ maiores.

As rotaçóes $B$ e $D$ trouxeram lucros, na media dos 12 anos, tanto no plantio direto quanto no convencional. Talvez o melhor desempenho da rotaçăo B em relaçăo 
à Ao contrário do que se poderia esperar. esteja associado ao maior volume de materia seca gerada pelo miIho, entre outras razóes que merecem ser averiguadas em outros estudos. E curioso salientar que o menor e o maior lucro ocorreram sob plantio direto, respectivamente nas rotaçós $A$ e D, revelando a importancia da escolha das rotaçธes.

MUZTLI (In: IAPAR, 1981), numa anklise dos 4 anos iniciais deste experimento, relata que as rotaços $B$ e, prineipalmente. D, mostraram maior acúmulo de matéria orgânica na camada aravel do solo, no sistema de plantio direto. O mesmo sucedeu com a rotação A no plantio convencional. Provavel mente, isto se manteve nos 2 períodos restantes, resul tando nestas diferenças agora reveladas.

Podemos resumir os lucros ro periodo, conforme a tabela 14. Note-se o expressivo salto nos lucros, quando se trabalha com a sucessão milhoxtrigo, ao ser adotado o plantio direto e, tambem, a superioridade da rotação $\mathrm{D}$ en relaçăo às demais. Al também, o plantio direto proporcionou incrementos significativos nos ganhos. superando a alternativa da rotaçăo $\mathbf{B}$ sob plantio direto, em 75, 2e OTN/ha, ou seja: 229\% a mais de 1 ucro 11 quido. No plantio convencional, o desempenho da rotaçă $S$ X $T$ X M foi altamente superior ao rodizio $M X T$ C58,73 OTNha versus 
3,52 OTN has.

Em ano de seca no inverno e má distribuição de chuvas no verăo (1985/86), o plantio direto trouxe melhores resultados que o convencional, para as rotaçóes $B$ e DC $25 \%$ e 59\%, e foi 5\%.inferior na rotaçă A que, alias, foi o menor indice (dos negativos) ocorrido nesta rotação, durante o estudo. Dai deduz-se a superioridade do plantio direto em anos desfavoráreis à produção agrícola.

Tabela 14 - Lucros COTN/has e imdices comparativos entre os sistemas de plantio (Dir/Conv), por rotação. $1976 / 1977$ a $1987 / 1988$.

\begin{tabular}{|c|c|c|c|c|c|c|}
\hline \multirow[b]{3}{*}{ Item } & \multicolumn{6}{|c|}{ Rotação } \\
\hline & \multicolumn{2}{|c|}{$A(S \times T)$} & \multicolumn{2}{|c|}{ E C $M \times T)$} & \multicolumn{2}{|c|}{$D C S \times T \times M D$} \\
\hline & Conv. & Dir. & Conv. & Dir. & Conv. & Dir. \\
\hline Luero & $-117,46$ & $-188,28$ & $3,5 z$ & 32,86 & 58,73 & 108,08 \\
\hline Dir $/$ Conv & \multicolumn{2}{|c|}{-60.29} & \multicolumn{2}{|c|}{833,52} & \multicolumn{2}{|c|}{84.03} \\
\hline
\end{tabular}

S=soja, $T=t r i g o$ e $M=$ milho

Fonte: Dados da pesquisa

Nesta safra, a produtividade das culturas em plantio direto fol superior em $24 \%$ para a soja na rotaça A. 20\% e 38\% para o milho, nas rotaçóes $B$ a D. o trigo năo foi colhido, devido à seca.

\subsubsection{Custos}

Nas 3 rotações estudadas, os maiores custos 
médios incidiram no plantio direto, como mostra a tabela 15. onde tambem vemos as diferenças entre os custos nos 2 sistemas de plantio.

A rotação A foi a que apresentou maior diferença de custos entre o plantio direto e o convercional; na rotaçäo $B$, esta diferemça foi muito pequena.

Observando-se as tabelas 9 e 15, percebemos que a rotaçáo $\mathrm{D}$ sob plantio direto a mais interessante em termos de receita e custo. pois f onde temos a maior diferença entre eles.

Conclui-se que, o aumento de ganhos no plantio direto superou os maiores custos, exceto na rotação A. Estes custos estão detalhados, por atividades, nos apendices 5 .

Tabela 15 - Custo medio (OTN/has e percentual de diferença de custos CPd/PCS entre os sistemas de plantio. $1976 / 1988$.

\begin{tabular}{|c|c|c|c|c|c|c|}
\hline & \multicolumn{6}{|c|}{ Rotação } \\
\hline & \multicolumn{2}{|c|}{$A C S \times T$} & \multicolumn{2}{|c|}{ E $C M \times T)$} & \multicolumn{2}{|c|}{$D(S \times T \times M)$} \\
\hline & Conv. & Dir. & Corr. & Dir. & Conv. & Dir \\
\hline $\begin{array}{l}\text { Custo } \\
\text { medio } \\
\text { CoTNhas }\end{array}$ & 788,40 & 935.47 & 787.19 & 832,25 & 765.07 & 860,91 \\
\hline $\begin{array}{l}\mathrm{Pd} / \mathrm{PC} \\
\mathrm{C} \infty \mathrm{S}\end{array}$ & \multicolumn{2}{|c|}{18.65} & \multicolumn{2}{|c|}{5,72} & \multicolumn{2}{|c|}{12.53} \\
\hline $\begin{array}{l}\text { S=soja, } T \\
\text { Fonte: } \mathrm{Da}\end{array}$ & $\begin{array}{l}\text { trigo e } \\
\text { os da pr }\end{array}$ & $\begin{array}{l}y=\text { mil ho } \\
\text { squisa }\end{array}$ & $\begin{array}{l}\mathrm{Pr} \\
\mathrm{Pr}\end{array}$ & $\begin{array}{l}=\text { plant } \\
=\text { plant }\end{array}$ & $\begin{array}{l}\text { o direte } \\
\text { o conver }\end{array}$ & =ional \\
\hline
\end{tabular}


Ao comparar os apendices 5 e verificamos

que:

- rotação A: o controle de ervas daminhas no plantio direto (169\% mais caros superou os gastos com o preparo do solo no plantio conventional, contribuindo para a melhor performance do plantio convencional na dobradinha $S X T$.

- rotação B: um 1 igeiro acréscimo nos gastos com o preparo do solo em contrapartida a uma maior economia com o controle de ervas no plantio direto, levaram a um resultado favoravel com esta tecnica $63,69 \%$, apesar de apresentar diferença de receita inferior a rotação A.

- rotação D: apresentou produtividades mais elevadas no plantio direto, trazendo maiores lucros e propiciando uma vantagem real de 5,08\% sobre o plantio convencional.

0 apendice 7 nos traduz estas diferenças, em termos de OTNrha.

As diferenças mais marcantes, em termos de custos e receitas, entre os dois sistemas de plantio, são: o controle de ervas, o preparo do solo e a produtividade, sendo as 2 últimas favoraveis ao plantio direto $e{ }^{\circ}$, ao converioional. 
Podemos avaliar o peso dos demais 1 tens de custo, nas 3 rotaçbes, e ver que eles pouco diferiram entre os sistemas de plantio (tabela 16$)$

Tabela 16 - Participaçáo dos custos $c \%$ nas atividades, por rotação e sistema de plantio - 1976/1977 a $1987 / 1988$.

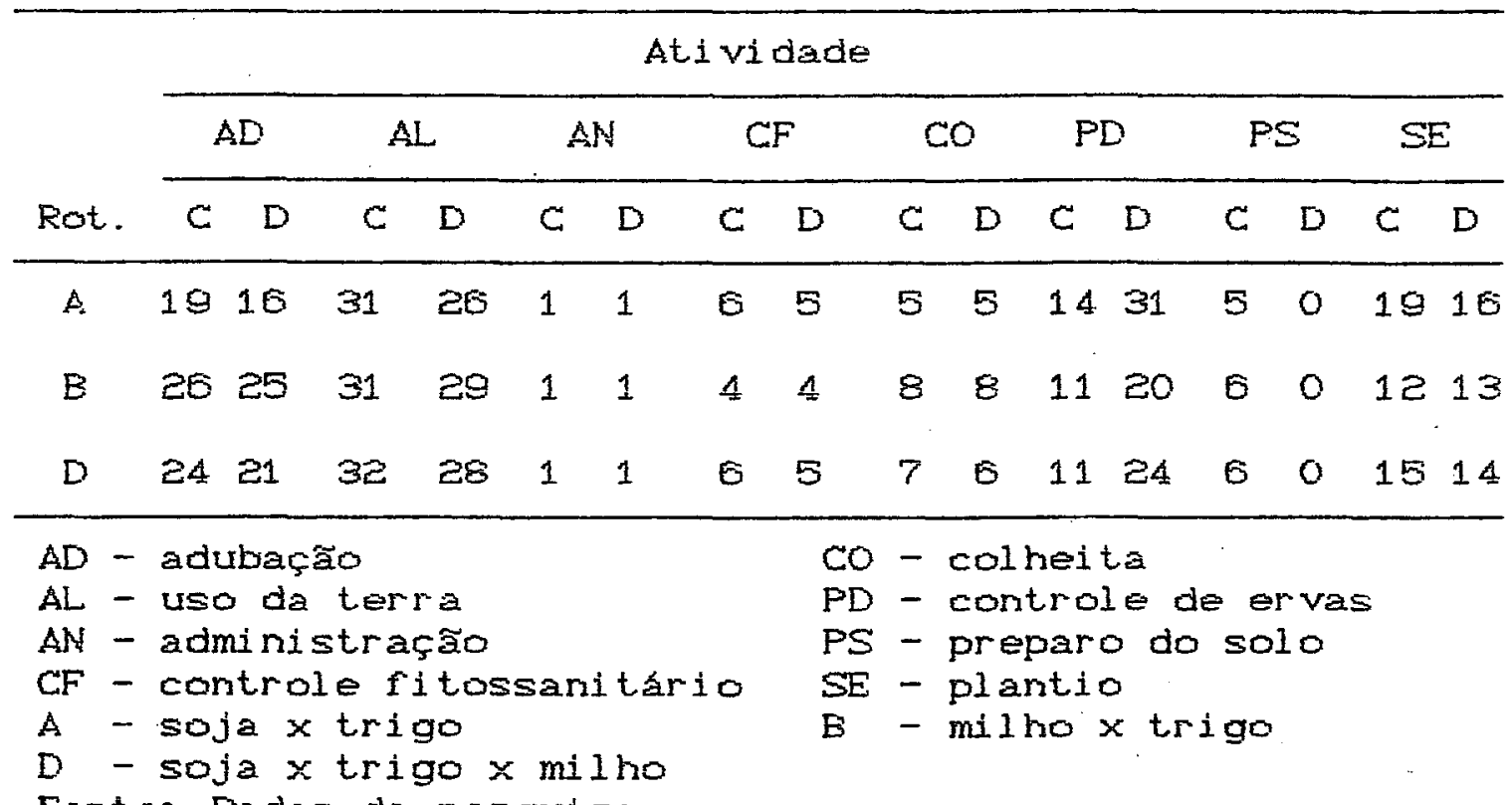

Fonte: Dados da pesquisa

Logo à primeira vista, percebe-se que a participaça dos custos por sistema de plantio foi praticamente a mesma, dentro de cada atividade, exceção feita a FD, com peso dobrado no plantio direto e PS, que incidiu apenas no plantio convencional. No convencional, os principais gastos, em ordem erescente, são: uso da terra (AL), adubação (AD), plantio (SE) e controle de plantas 
daninhas (PD). Para o plantio direto, esta ordem é alterada apenas pelo posicionamento do controle de ervas em $z^{\circ}$ lugar. Vemos que, o custo $f 1 \times 0$ da utilização da terra e bastante elevado e, por isto, deve ser sempre levado em consideração, neste tipo de análise.

No nosso caso, durante os 4 primeiros anos. - preço da terra manteve-se praticamente inalterado, com uma média de 12,44 OTN/ha ano, passando para 23,92 OTN/ha ano nos anos seguintes, o que significa um salto de $92 \%$. Este fol o maior custo, em todas as rotaçoses e respectivos sistemas de plantio, com excessão da rotacão A sob plantio direto, onde o controle de ervas fol $19.23 \%$ superior, repre- sertando o principal gasto.

Na tabela anterior verifica-se, aimda, que nas rotaçós em que o plantio direto superou o convencional $C B E D$, todos os itens de custo do plantio direto tiveram peso inferior ou igual ao convencional, exceto o controle de ervas, que contribuiu com praticamente o dobro da partielpaça do plantio convencional. O fato de se utilizar maquinas mais caras na semeadura CSE par o plantio direto, praticamente não teve importancia, neste estudo.

Conclui-se, do exposto, que o objetivo de reduzir os gastos com controle de ervas no plantio direto. deve ser perseguido com arinco, visto que al reside a 
principal diferença de custos em relação ao sistema convencional. Uma vez que as produtividades se mostraram significativamente superiores sob plantio direto, demonstrando maior adequação deste sistema às condiços ambientais de produção, ao se lograr a diminuiç̃o de gastos, o sistema fica ainda mais vartajoso.

Hoje em dia, ja se conseguem grandes economias neste controle, através do manejo na época certa, da erradicaçăo das ervas perenes, de determinadas rotaçós de culturas, da espessurá da camada de palna e do uso de herbicida pós-emergentes.

\subsection{Escolha das alternativas}

Apos submeter os dados aos eriterios de Media-Variância e Dominância Estocástica, selecionou-se as alternativas que passamos a apresentar.

\section{2.1. Seleção pela Média-Variáncia}

Das $B$ alternativas em questão, apenas 4 apresentaram lucros, situando-se no $1^{\circ}$ quadrante do grafico da média do lucro ECX en funcăo da sua variancia $V(x)$, representado pela figura 6 . Entre estas, 6 preciso ldentificar as que estão na fronteira eficiente (AA'), que nos indica os portos de nenor risco, para um dado nivel de 


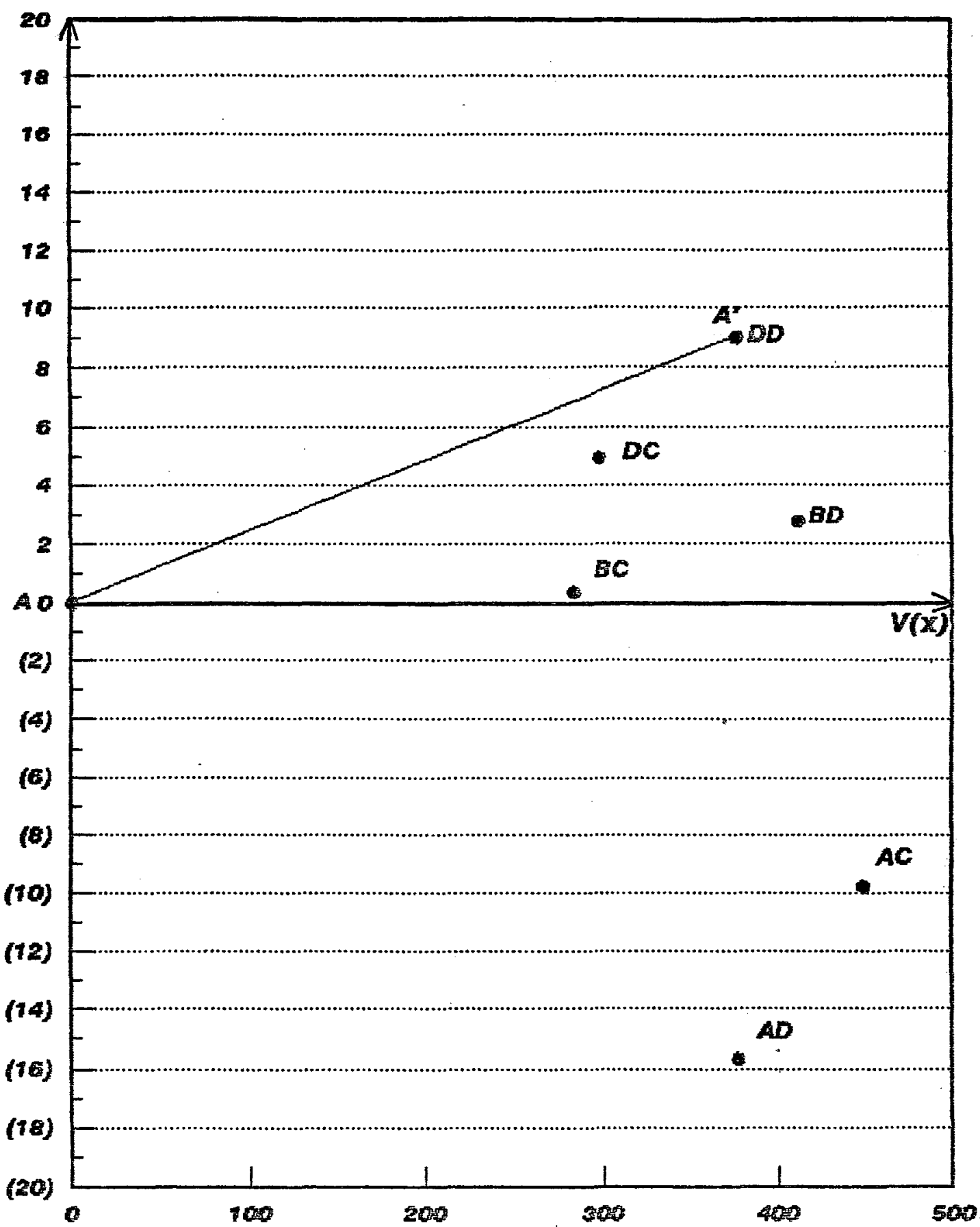

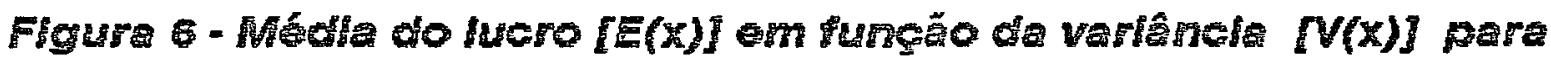

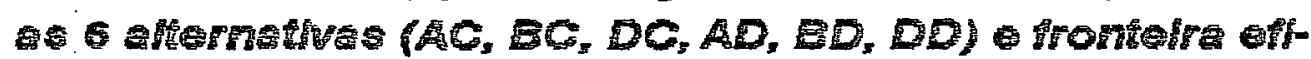
clente AA'. 
retorno. ou seja, as melhores alternativas, para um mesmo nivel de risco ou renda.

Para definirmos graficamente esta fronteira, traçamos uma reta paralela 20 eixo $Y$, partindo da origem $E$ girando no sentido horário, ate cruzarmos com a $1^{\circ}$ alternativa. No mosso caso, a alternativa encontrada foi a DD - (rotação D sob plantio direto); qualquer outra que esteja na área abaixo da reta $A A^{\prime}$, resultou numa combi nação menos interessante de expectativa de ganhos e respectivos riscos envolvidos.

Assim, dentre as alternativas propostas, aperas uma foi escolhida, atraves deste critério de escolha, facilitando sobre maneira, a orientaçăo técnica ao agricultor.

\section{2. 2. Seleção pela Domi náncia Estocástica}

$$
\text { Foram traçadas as curvas de funcão }
$$

cumulativa das probabilidades de retornos, 6 no total, para cada alternativa possivel, conforme a figura 7 , que define $01^{\circ}$ grau de dominâneia.

O fato das curvas terem se cruzadado en alguns momentos, não permitiu a escolha nesta etapa, apesar da alternativa DD mostrar-se mais a direita. Procedeu- se, então, ao exame do $e^{\circ}$ grau de dominancia, que confirmou ser 
esta alternativa a melhor opcão. Este resultado coincide com o encontrado pela media-variancla, confirmando a equivalencia entre estes dois criterios, aportada por diversos autores. 


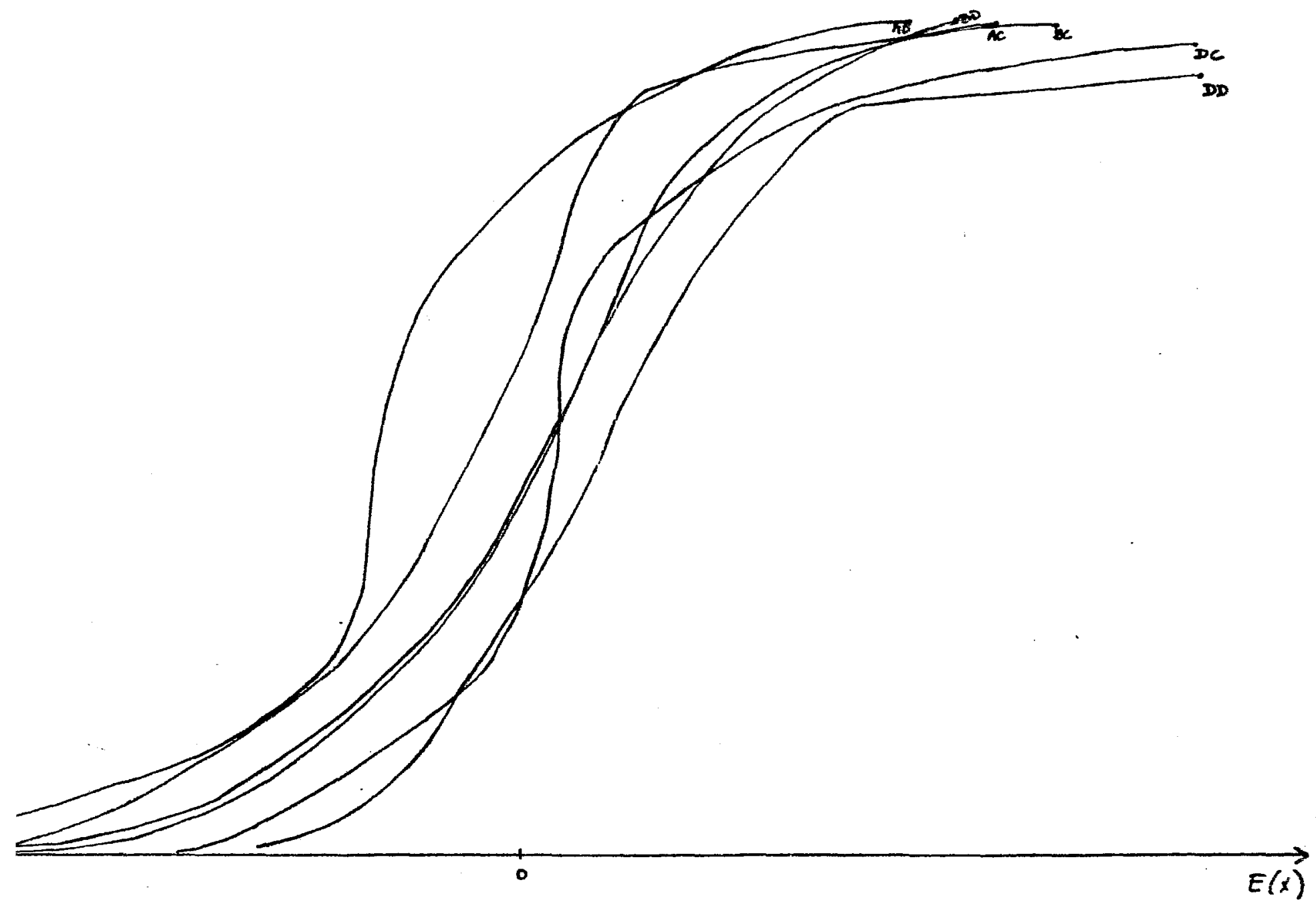

FIGURA 7 - Curvas das funçóes cumulativas de probabilidade das 6 alternativas $(A C, B C, D C, A D, B D e D D$ 


\section{CONCLUSOES E SUGESTÕES}

Os resultados mostram que, para o nosso caso, o plantio direto foi o sistema que trouxe melhores resultados em termos de lucro, levando-se em considerá̧ăo risco ervolvido, em ambos os criterios de analise adotados. Some-se a isto, o fato desta tecnica contribuir para a manutenção, senão recuperaçăo, do equilibrio ambiental, uma vez que năo há perdas expressivas de solo, com todas as vantagens que isto sigrifica.

A maior flexibilidade das atividades de plantio e tratos culturals que este sistema possibilita, é outro aspecto de grande importancia para o agricultor, que pode administrar melhor seu tempo e não se expß̊ tanto aos reveses climáticos.

A estrutura de preços e o comportamento das produtividades ao longo dos anos mostraram que, o plantio direto e um sistema que requer habilidade administrativa $e$ - acompanhamento ténico cuidadoso, através de medidas tomadas antes e durante a sua implementação e uso. 
A escolina da sucessão de culturas mostrou ser determinante, na natureza dos resul tados alcançados.

\subsection{Limitações do estudo.}

Este trabalio, tendo por base dados experimentais, refere-se a um caso determinado e, portanto, qualquer extrapolação deve ser feita com a devida oriertação, de forma a contemplar as caracteristicas de cada situaçăo.

Durante os anos deste estudo, as máquinas utilizadas em plantio direto sofreram sensiveis modificaç̧es, evoluindo para uma melhor adequação. às necessidades especificas deste sistema coortar a palhada, acomodar a semente, evitar revolvimento e compactação do solo etcj. Alem disso, tendo uma area bastante inferior às cultivadas em propriedades rurais, o movimento de máquinas dentro das parcelas experimentais e muito maior. agravando consideravel mente o problema da compactaça. Visto que, no plantio direto náo se movimenta o solo para a semeadura, este sistema verse particularmente prejudicado pelo excessivo adensamento do solo. Estes aspectos podem estar mascarardo os resultados, prejudicario o desempenho do plantio direto, apesar de ter alcançado as produtividades mais elevadas. 
Em se tratarido de um ensaio, o nivel economico para se proceder ao controle de doenças, ervas e pragas, não fol aguardado. Um manejo mals adequado as reals condiç̧⿸s de produçăo seria, com certeza, menos dispendioso.

For outro lado, a obtenção de Informaçß̄es seguras, ao longo dos vários anos, garante o nível de confiança necessario, nos resultados apresentados. Além disso, como instrumento de comparação, utilizamos o lucro 1 iquido, onde estão refletidos os riscos de mercado cpreços de insumos e dos produtos) e de elima (volume anual de produçãos, principais limitantes da atividade agricola. Desta forma, alcança-se razoável grau de riqueza na aralise.

\subsection{Sugestões para proximos trabal hos}

Muitos estudos ainda são necessários para o melhor balizamento dos técnicos e agricultores, na adoção do plantio direto. Aspectos como a diferenca de produtividade associada às condiçoses edaro-climáticas s suas alterações, merecem ser aprofundados.

A sequéncia de plantio das diferentes culturas implica em consequencias que se mostraram decisivas para o alcance de melhores retornos do investimento, com maior certeza de sucesso. Negligeneiar 
este aspecto, pode significar um subaproveitamento dos recursos aplicados e, ate mesmo, prejuizos reais.

Acompanhar o comportamento das plantas Invasoras e sugerir controles mais eficazes e económicos, constitui-se numa das principais contribuiçסes aqueles que pretendem trabalhar com o plantio direto. permitindo-lhes contornar um dos maiores obstaculos à utilização desta tecrica.

Seria interessante obter-se dados de acompanhamento de lavouras onde, tanto o plantio direto quanto o convencional fossem praticados, possibilitando uma analise mals proxima da realidade. A malor dificuldade para isto, consiste na falta de anotaçßes nas propriedades agricolas, que possibilitem uma serie historica suficiente - confiável. Outros empecilhos comums, dizem respeito a alternação dos sistemas de plantio nos talhães, aos diferentes tipos de solo sob cada sistema, a quantificação da produção elou outros parametros de forma năo diferenciada etc. 


\section{REFERENCIAS BIBLIOGRAFICAS}

ACOMPANHAMENTO DA SITUAÇAO AGROPECUARI A DO PARANA, Cur It 1 ba, v. $1-13,1976-1987$.

ALMEIDA, F.S. Controle de ervas. O plantio direto no Para ná, Londrina, 1981 p. $101-38$ CIapar, Circular, 23).

ALMEIDA, F.S.; VIDAL, A.R.; RODRI GUES, B.N. Estudo de rotaçōes em plantio direto, vizando a redução do uso de herbicidas. I apar, Londrina, 1985.

ANDERSON, J.R., DILLON, J.L.; HARDAKER, E. Agricultural decision analysis. Iwoa, Iowoa State University Press, 1977. 34p.

ANUARIO ESTATISTICO DO BRASIL. RIO de Janeiro, 38: $847 p$, 1977 .

ANUFARIO ESTATISTICO DO BRASIL. RIo de Janeiro, 49, 784P, 1989.

ARROW, K.J. Essays in the theory of risk-bearing. $Z$. ed. Amisterdan, North-Holland, 1974. 278p.

BAKAJEV, N.M. Effects of straw mulching in a "summer fallow-3 times spring wheat" rotation in Northern Kazakhstan, U.S.S.R.. Soil and Tiliage Research, Amsterdan, 1(3): 239-51, ago. 1981 .

EALASTREIRE, L. A. Análise tecnologica da maquinária agricola. Piracicaba. FEALQ, 1978. 190p. CRelatório do pro jetos.

BARBOSA, M.M.T.L. O efeito do risco nos planos de produção: um estudo de caso. Viçosa, 1976 . $81 \mathrm{p}$ CM.S. - Uni versidade Federal de Viçosal. 
BARNARD, C.S. \& NIX.' J.S. Farm planning and control. 2. ed. Cambridge, Camb. Univ. Press, 1979. 600p.

BENATTI, J.R. Perdas por erosão em plantio direto e convencional de milho, em $z$ solos de Sá Paulo. Revista Brasileira de Ciencia do Solo, Campinas, $1(2 / 3)$ : 121-3, mato 1977.

BISERRA, J.V. Uncertainty and decision analysis on large sharecropped farms in Northeast Brazil. Ohio, 1980. (M.S. - The Ohio State University).

BISERRA, J.V. Atitudes dos produtores de abacaxi em relafão do risco; Estado da Paraiba. Fortaleza. Universidade Federal do Ceará, 1985 ėp. (Pesquisa, 38 ).

CARGILL., Atualizacão em plartio direto. Campinas, 1985. $343 \mathrm{p}$.

CASSOL, E.A. Perdas do solo por erosão sob chuva natural na cultura da soja, em manejo de solo convencional e em plantio direto, em solo "Santo Angelo" CLatossolo Roxo distroficos. In: REUNI AO SOBRE PLANTIO DIRETO,1., Londrina, 1977. Stntese. Londrina, EMBRAPA,CNPSo, 1977 p. $22-4$.

CORSINI, P.C. Modificaçöes de caracteristicas fisicohidricas em perfis das steries Jaboticabal e Santa Tereza, ocasionadas pelo cultivo intenso. Cientifica, Jaboticabal, eC2): 148-61, jul. 1974.

DANIEL, L. A. Análise do comportamento da cultura do milho (Zea mays, L.) em rotação com soja colycine max, (L) Merril1s, cultivadas através dos sistemas de "Plantio Direto" e "Convencional", em diferentes" épocas do ano. com e sem irrigação. Jaboticabal, 1981. 111p. (M.S.Universidade Estadual Paulistas.

DEDECEK, R. Pesquisa em sistema de preparo conservacionista do solo. In: REUNIAO SOBRE PLANTIO DIRETO,1., Londrina, 1977. Sintese. Londrina, EMBRAPACNPSO, 1977. P. 17-2Z.

DERPSCH, R.W. Impacto ecológico do sistema de plantio direto. In: PROJETO DE CONTROLE DA EROSAO NO ESTADO DO PARANA. Relatorio final. Londrina, Iapar, 1984, P. $21-7$. 
DERPSCH, R.W. Erosion problems in Paraná. Brazil. Research results and strategies for the implementation of efficient soil conservation measures. Reading, 1986. 150p. (M.S. - Reading University).

DILLON, J.L. Avaliação de tecnologias agricolas alternativas, sob risco. Revista de Economia Rural, Brasilia, 15(2): 17-41, $1977 \mathrm{a}$.

DILLON, J.L. The analysis of response in crop and investock production. z. ed. New York. Fergamon International Library, 1977b.

ELTZ, F.F.F. Perdas por erosão em diferentes manejos de solos e coberturas vegetais, em solo Lateritico Bruno Avermelhado distrófico (São Jerónimo). Revista Brasileira de Ciencia do Solo, Campinas, $1(2 / 3)$ : 123-7, maio 1977 .

EMPRESA DE ASSISTENCIA TECNICA E EXTENSAO RURAL. Metodorogia para elaboracão do custo total de producão de lavouras temporbrias - Região Sul do Brasil. Curitiba, 1988. 20p.

EMPRESA BRASTLEIRA DE PESOUISA AGROPECUARIA. O uso da plarilha eletronica no administracão rural; um modelo de custos de produção. Londrina, 1987. 19p.

EMPRESA BRASTLEIRA DE PESQUISA AGROPECUARI A CENTRO NACI ONAL DE PESOUISA DA SOJA. In: Reunião sobre Plantio Direto. Lordrina, 1977. $81 \mathrm{p}$.

FERNANDES, $B$. The effect of tillage systems on soil physical properties. Purdue, 1976. 101p. CPhd Purdue Universitys.

FRIEDMAN, M. \& SAVAGE, L.J. The utility analisys of choices involving risk. Journal of Political Economy, Chicago, 56: 279-304, Ago, 1948.

GARCIA, J.C. \& CRUZ, J.C. Seleção pela domináncia estocástica, de praticas agricolas eficientes com respeito ao risco - uma aplicação para a cultura de milho. Revista de Economia Rural, Brasilia, 17(2): 131-42, abr. /jun. 1979. 
GARCIA, J.C. \& RUAS, D.G.C. Seleção de sistemas de produção para milho, em condiçóes de risco. Revista de Economia Rural, Brasilia, 19(4): 585-95, out./dez. 1981.

HILL, F.G. Regional aspects of economic development. Land Economics, Hisconsin, 38C 3 : 85-98, maio $196 \mathrm{e}$.

HOFFMANM, R. Estatistica para economistas. São Paulo, Pioneira, 1980. $379 p$.

INSTI TUTO AGRONOMI CO DO PARANA-FUNDACEO INSTI TUTO AGRONBMI CO DO PARANA. Progr ama de manejo e conservação dos solos. Relatótio Técnico Anual, 1977. Londrina, 1978. p. 221-31.

INSTITUTO AGRONOMICO DO PARANA. Programa de Manejo e ConServaço dos Solos. Relatorio Técrico Anual, 1978. Londrinf, 1979 . p. 205-18.

INSTI TUTO AGRONOMICO DO PARANA. O plantio direto no Estado do Parand. Londrina, 1981. 244p. CIapar, Circular, 233

INFORMACOES ECONOMI CAS, SãO PaUlo, Y. 6, 1976.

JONES JR.; J.N. The no-tillage system for corn Czea mays, L. 3 . Agronomy Journat, Madison, 60(1): 17-20, Jan. Fev. 1968.

KEMPER, B. \& DERPSCH, R. Results of studies made in 1978 and 1979 to control erosion by cover crops and no-tillage techniques in PE-Brazil. Soil and Tillage Research, Amsterdan, 1(3): 253-67, ago.1981.

KINJO, T. et alii. Movimentaçăo do nitrato em colunas de terra de um latossolo. Revista de Ciencia do Solo, Campinas, 2C2): 108-09, 1978.

KNIGHT, F.H. Risk, uncertainty and profit. Chicago, The University of Chicago Press, 1971. 375p.

KOHNKE, H. Mulch culture, soll temperature and corn growth. In: CONGRESSO PAN-AMERT CANO DE CONSERVAÇAO DE SOLOS, Sa Paulo, 1966. Anais. Săo faulo, 1966.

KONDORFER, G.H. Energia na agricultura. Anais. Jaboticabal , Funep, 1984. 505p. 
KUGIZAKI, Y. Proposta metodológica para simplificação do PACTA. Revista de Economia Rural. Brasilia, zoces: 317-24, 1982.

MACHADO, J.A. Efeito dos sistemas de cultivo reduzido e convencional na alteração de algumas propriedades fisicas e químicas do solo. Santa Maria, 1976. 129p. CLivre-docencia - Universidade Federal de Santa Marias.

MACHADO, J.A. \& BRUM, A.C.R. Efeito de sistemas de cultivo em algumas propriedades risicas do solo. Revisia Brasileira de Ciencia do Solo, Campinas, 2CZ: 81-4. maio 1978.

MARQUES, J.Q.A. \& BERTONI, J. Sistemas de preparo do solo em relação à produção e à erosão. Bragantia, Campinas, 20(9): 403-59, jar.1961.

MENDES, J.T.G. \& DOSSA, D. Crescimento da agricultura parancense no período de 1970,80. Curitiba, SEAG/DERAL, 1981. $73 p$.

MI ALHE, L.G.; NORONHA, J.F.; JACINTHO, C.P. Evolucdo dos preços de tratores agricolas brasileiros no periodo 1983-87; formulario para trabalho tecnico e resumo. Piracicaba, ESALQ, 1987. $11 p$.

MONDARDO, A. Informaçôes preliminares da pesquisa sobre erosão em trigo-soja, em diferentes sistemas de manejo de solos no Paraná. In: REUNIÃO SOBRE PLANTIO DIRETO, 1. Londrina, 1977. Sintese. Londrina, EMBRAPACNFSO, 1977. p. 59-62.

MONTOYA, L.J. Aspectos de economicidade e magnitude de algumas externalidades do manejo do solo em plantio direto. Londrina, IAPAR, 1984. 23p.

MOUTINHO, D.A. Escolha de nova tecnologia sob condiços de risco: o caso do feijão de corda em Quixadá. Fortaleza, 1977. 118p. CM.S. - Universidade Federal do Ceara).

MUZILli, 0 . Influencia do sistema de plantio direto, comparado ao plantio convencional, sobre a fertilidade da camada arável do solo. Reuista Brasileira de Ciencia do Solo, Campinas, 7(1): 95-102, 1983. 
NOGUEIRA, A.C. Risco e incerteza na combinação de atividades agricolas nos estados de Minas Gerais e Goías. Viçosa. 1974. 59p. (M.S. - Universidade Federal de Viçosal.

NORONHA, J.F. Projetos agropeculuios; administração financeira, orçamento e viabilidade económica. 2.ed. São Paulo, Atlas, 1987. 269p.

ORGANI ZACAO DAS COOPERATI VAS DO ESTADO DO PARANA. ONganIZação de Cooperativas do Parana. Custo de producão, safra 86/87. Curitiba, 1986. $138 \mathrm{p}$.

ORTOLANI, A.F. Efeitos de diferentes tipos de preparo do solo. sobre o comportamento do sistema solo - cultura, de milho (Xea mays). Jaboticabal, 1977. (MS - Universidade Estadual Paulista/NESPS.

PACHECO, J.A.C. Modelos de decisão na análise económica de experimentos agricolas. Piracicaba, 1985. $111 \mathrm{p}$. CM.S. Escola Superior de Agricultura Luis de Queiroz/USPD.

PERES, A.R.F. Produtividade do milho como consequencia da tomada de decisão sob condiçóes de risco na agricultura. Piracicaba, 1981. 118p. CM.S. - Escola Superior de Agricultura Luis de Queiroz,USPS.

PORTO, V.H.F., Cruz, E.R., INFELD, J.A. Metodologia para incorporação do risco em modelos de decisão usados na analise comparativa entro alternativas - o caso da cultura do arroz irrigado. Revista de Economia Rural, Brasilia, 20C2): 193-211, abr. /jun. 1982.

PREÇOS PAGOS PELOS AGRICULTORES - MEDIAS MENSAIS 1976, RIO de Jameiro, F.G.V. . 1977.

RAMOS, $M$. A pesquisa sobre sistemas de preparo minimo no Parana - resultados e primeiras conclusós. In: REUNI TO SOBRE PESQUISA EM PLANTIO DIRETO, 1, Londrina, 1977. Sintise. Londrina, EMBRAPACCNPSO, 1977.

RANDO, E.M. Alterações nas caracteristicas e propriedades flsicas de um Latossolo Roxo distrofico, ocasionadas pelo cultivo convencional. Lavras, 1981. 161p. CM.S.

- Escola Superior de Agricultura de Lavras. 
SAAD, O. Selecõo do equipumento agricola. 4. ed. Sro Paulo, Nobel. $1986127 \mathrm{p}$.

SAMUELSON, P.A. The fundamental aproximation theorem of portfolio analysis in therms of mean, variances and higher moments. The Review of Economic Studies, New York, 37(4): 537-42, no 11e, 1970.

SANTOS, M.L. Determinação de planos de produção agricola em áreas de colonizaçăo, Itaituba - Para. Viçosa, 1980. 71 p. CM.S. - Universidade Federal de Vicosas.

SHEAR, R.L. \& MOSCHLER, W.M. Continuous corn by the no tillage and conventional practices Agronomy. Journal. Madison, $61(4): 524-6,1969$

SIDIRAS, N. Influência de diferentes sistemas de preparo do solo na variaçăo da umidade e rendimento da soja, em Latossolo Roxo distrofico COxisolj. Revista Brasileira de Ciencia do Solo, Campinas, 7(1): 103-6, jar. 1983.

SIDIRAS, N. Efeitos de plantio direto, escarificaçăo, arado de discos e cobertura verde permanente sobre algumas propriedades físicas do solo, à desagregaçăo por impacto de gotas e à erosão. Londrina, 1984 . Convenio IAPAR/GTZ - jar. 'set. 1984. 44P. CIAPAR - Programa de manejo e conservaça de solos. Relatorio final do projeto.

SORRENSON, W.J. \& MONTOYA, L.J. Implicaç̃es econBmicas da erosão do solo e das praticas conservacionistas no Parana, Brasil. Londrina, 1894. $146 \mathrm{p}$.

TOBIN, J. Liquidity preference as behavior towards risk. Review of Economics Studies. New York, 25(1), 1958.

TOMASINI, R.G.A. Economicidade da semeadura direta na cultura de trigo - 1976. In: REUNIÃO ANUAL CONJUNTA DE PESQUISA DE TRIGO, 9., Londrina, 1977 , p. $29-35$.

TOMASINI, R.G.A. Semeadura direta de trigo e soja; recomendaçoses tecnicas para o Estado do Rio Grande do Sul. Passo Fundo. EMBRAPA, 1977b. 6p.

TSIANG, S.C. The rationale of the mean-standard deviation analysis, skewness preference and the demand of money. American Economic Keview, 6z, Jun. 1972. 
VIEIRA, M.J. Cultivo mínimo comparado a outros sistemas. efeitos no solo e na planta. In: FERREIRA, M.E.; PEREIRA, V.P.; CRUZ, M.C.P. Energia na Agricultura. Arais Jaboticabal, FUNEP, 1984. $505 p$.

VOGEL, R.J. \& HAHN, A. On the preservation of agricultural 1 and. Land Economics, Wisconsin, 48(2): 190-3, 1972. 


\section{APÊNDICE}

Apendice 1 - Produtividade do milho par sistema de cultivo e rotação. Londrina $1976 / 1988$ Cmédia de 3 repetiçธ̌s?.

\begin{tabular}{|c|c|c|c|c|}
\hline \multirow[b]{3}{*}{ Safra } & \multicolumn{4}{|c|}{ Rotação } \\
\hline & \multicolumn{2}{|c|}{ B $C M \times T)$} & \multicolumn{2}{|c|}{$D C S \times T \times M$} \\
\hline & Conv. & Dir. & Conv. & Dir. \\
\hline $1976 / 77$ & 5.606 & 4.868 & \multicolumn{2}{|c|}{ Soja } \\
\hline $1977 / 78$ & 5.678 & 6. 489 & 5.548 & 5. 981 \\
\hline 1978,79 & 3.042 & 3.796 & \multicolumn{2}{|c|}{ Soja } \\
\hline 1979,80 & 0.107 & 4.714 & 5.439 & 5. 727 \\
\hline Media $1^{\circ}$ fase & 5.108 & 4.967 & 5.493 & 6. 354 \\
\hline $1980 / 81$ & 4.669 & 4.651 & \multicolumn{2}{|c|}{ Soja } \\
\hline $1981 / 82$ & 7.131 & 6. 839 & 7.965 & 7.862 \\
\hline $1982 / 83$ & 5.267 & 5.975 & \multicolumn{2}{|c|}{ Soja } \\
\hline $1983 / 84$ & 4.568 & 4.914 & 5.392 & 6.157 \\
\hline Media $e^{\prime}$ fase & 5.409 & 5.595 & 6.678 & 7.009 \\
\hline $1984 / 85$ & 4.129 & 3.822 & \multicolumn{2}{|c|}{ Soja } \\
\hline 1985,86 & 4.073 & 4.871 & 4. 226 & 5.832 \\
\hline $1986 / 87$ & - & - & \multicolumn{2}{|c|}{ Soja } \\
\hline $1987 / 88$ & ㅅ. $52 Z$ & 5.342 & 5.909 & 6. 578 \\
\hline Média $3^{\circ}$ fase & 4. 241 & 4.678 & 5.067 & 0.205 \\
\hline Media Total & 4. 981 & 5.116 & 5.746 & 6.523 \\
\hline
\end{tabular}

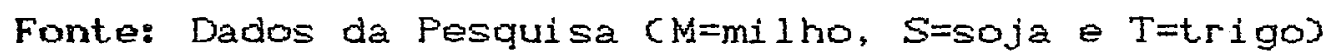


Apêndice 2 - Produtividade da soja por sistema de cultivo e rotação. Lordirina $1976 / 1988$ Cmedia de 3 repetiçổes.

\begin{tabular}{|c|c|c|c|c|}
\hline \multirow[b]{3}{*}{ Safra } & \multicolumn{4}{|c|}{ Rotação } \\
\hline & \multicolumn{2}{|c|}{$A(M \times T)$} & \multicolumn{2}{|c|}{ D. $C S \times T \times M$} \\
\hline & Conv. & Dir. & Conv. & Dir. \\
\hline $1976 / 77$ & 3.230 & 3.280 & 2.939 & 3.247 \\
\hline $1977 / 78$ & 530 & 1. 448 & \multicolumn{2}{|c|}{ Milno } \\
\hline $1978 / 79$ & 2.006 & 1.019 & 2. 194 & 1.804 \\
\hline $1979 / 80$ & 2.392 & 1.488 & \multicolumn{2}{|c|}{ Milho } \\
\hline Média $1^{\circ}$ fase & 2.039 & 1.959 & 2.566 & 2.525 \\
\hline $1980 / 81$ & 2. 352 & 3.163 & 2. 291 & 3.296 \\
\hline 1981,82 & 1.882 & ㄹ. 279 & \multicolumn{2}{|c|}{ Milho } \\
\hline 1982,83 & 1.375 & 1.811 & 1.200 & 2.088 \\
\hline $1983 / 84$ & 1. 464 & 1.708 & \multicolumn{2}{|c|}{ Milho } \\
\hline Media $e^{\circ}$ fase & 1.768 & 2. 240 & 1.745 & 2. 692 \\
\hline $1984 / 85$ & 1.961 & 1.800 & 1.860 & 2. 136 \\
\hline $1985, / 86$ & 1.432 & 1.772 & \multicolumn{2}{|c|}{ Milho } \\
\hline $1986 / 87$ & -- & -- & - & - \\
\hline 1987.88 & 1.952 & 1. 982 & \multicolumn{2}{|c|}{ Milho } \\
\hline Média $3^{\circ}$ fase & $1.78 \mathrm{Z}$ & 1.845 & 1.860 & 2. 136 \\
\hline Média Total & 1.870 & 2. 030 & 2.097 & ㄹ. 514 \\
\hline
\end{tabular}

S=soja, M=milho e T=trigo

Fonte: Dados da pesquisa. 
Apêndice 3 - Produtividade do trigo por sistema de cultivo e rotação. Londrina $1976 / 1988$ cmédia de 3 repetiçbes).

\begin{tabular}{|c|c|c|c|c|c|c|}
\hline \multirow[b]{3}{*}{ Safra } & \multicolumn{6}{|c|}{ Rotaçäo } \\
\hline & \multicolumn{2}{|c|}{$A(S \times T)$} & \multicolumn{2}{|c|}{$B \subset M \times T)$} & \multicolumn{2}{|c|}{$D C S \times T \times M D$} \\
\hline & Conv. & Dir. & Conv. & Dir. & Gonv. & Dir. \\
\hline $1976 / 77$ & 609 & 967 & 523 & 1.69 & 642 & 1.049 \\
\hline $1977 / 78$ & 507 & 2.036 & 671 & 2. 41 & 723 & 2. 446 \\
\hline 1978,79 & 1.854 & 1.281 & 1.777 & 1.65 & 2. 018 & 1.314 \\
\hline 1979,80 & 1.867 & 1.799 & 1.641 & 1.75 & 1.713 & 1.609 \\
\hline Med $1^{\circ}$ fase & 1.209 & 1.521 & 1.153 & 1. $\mathrm{BZ}$ & 1. 274 & 1. 616 \\
\hline $1980 / 81$ & 676 & 1.393 & 559 & 1.59 & 496 & 1. 527 \\
\hline $1981 / 82$ & 1.104 & 1.054 & 822 & 01 & 978 & 903 \\
\hline $1982 / 83$ & 1.551 & 1.617 & 838 & 89 & 1.638 & 1.542 \\
\hline $1983 / 84$ & 347 & 586 & 493 & 03 & 497 & 985 \\
\hline Med $z^{\circ}$ fase & 919 & $1.16 \mathrm{Z}$ & 678 & 1.88 & 902 & 1. 239 \\
\hline 1984,85 & 1.430 & 1.869 & 1.433 & 1.36 & 1.494 & 1. 859 \\
\hline $1985 / 86$ & - & - & - & & - & - \\
\hline $1986 / 87$ & 2.777 & 2. 402 & 2. 242 & 1.41 & e. 809 & z. 762 \\
\hline $1987 / 88$ & 1.460 & 1.680 & 1. 491 & 1.33 & 1.439 & 1.609 \\
\hline Med $3^{\circ}$ fase & 2. 103 & 2.135 & 1. 837 & 1.38 & 2. 151 & 2. 310 \\
\hline Med Total & 1. 272 & 1.500 & 1.100 & 1.48 & 1.301 & 1.004 \\
\hline
\end{tabular}

S=soja, M=milho e T=trigo

Fonte: Dados da pesquisa. 
Apéndice 4 - Lucro por sistema de plantio e rotação.

Sistewa de plantio C

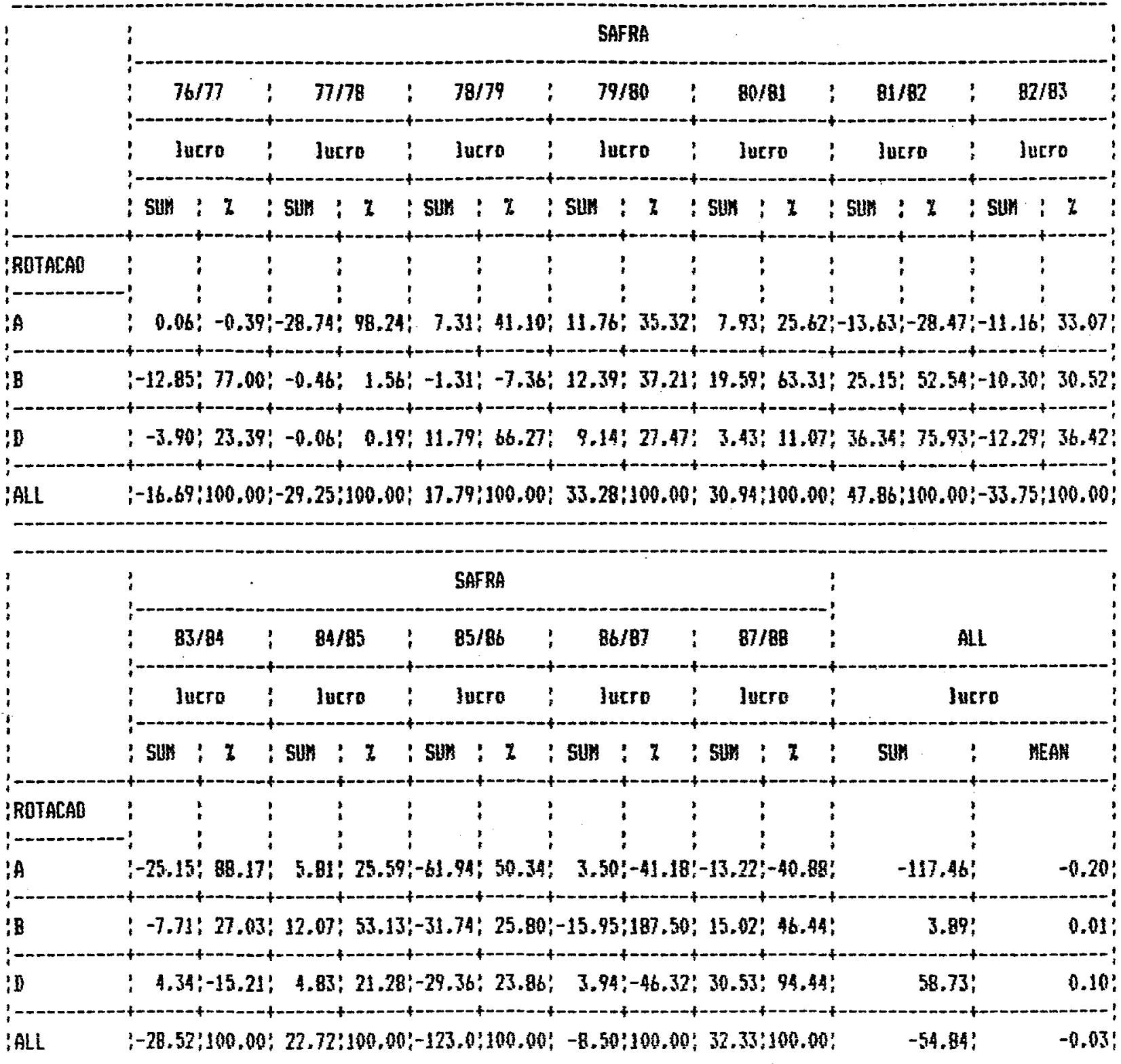


Apéndice 4 - Lucro por sistema de plantio e rotação.

Sistere de plantio 0

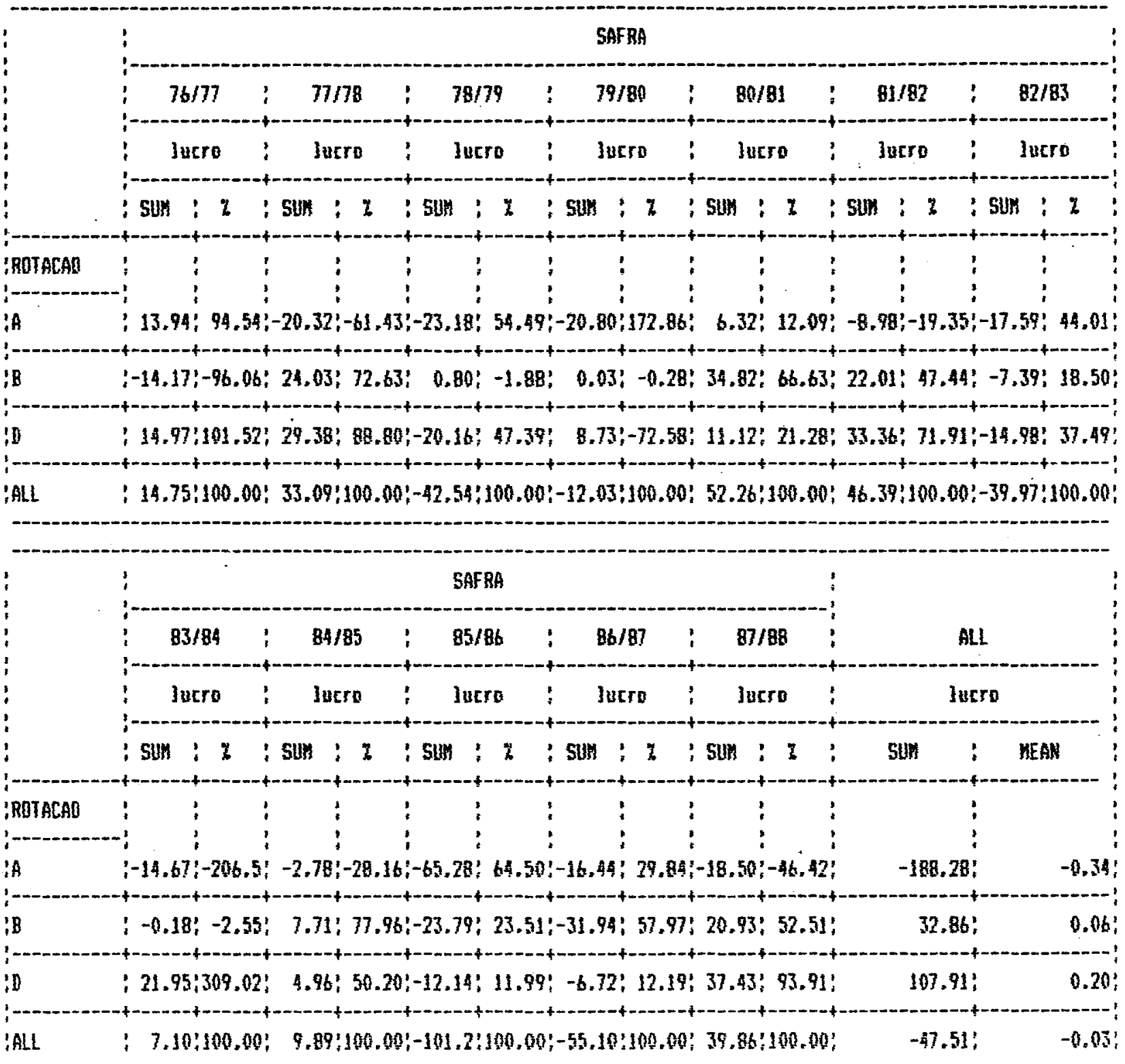


Apendice 5 - Gastos nas operaçzes, por rotação, em plantio direto e convencional.

Sistesa de plantjo C e rotacan A

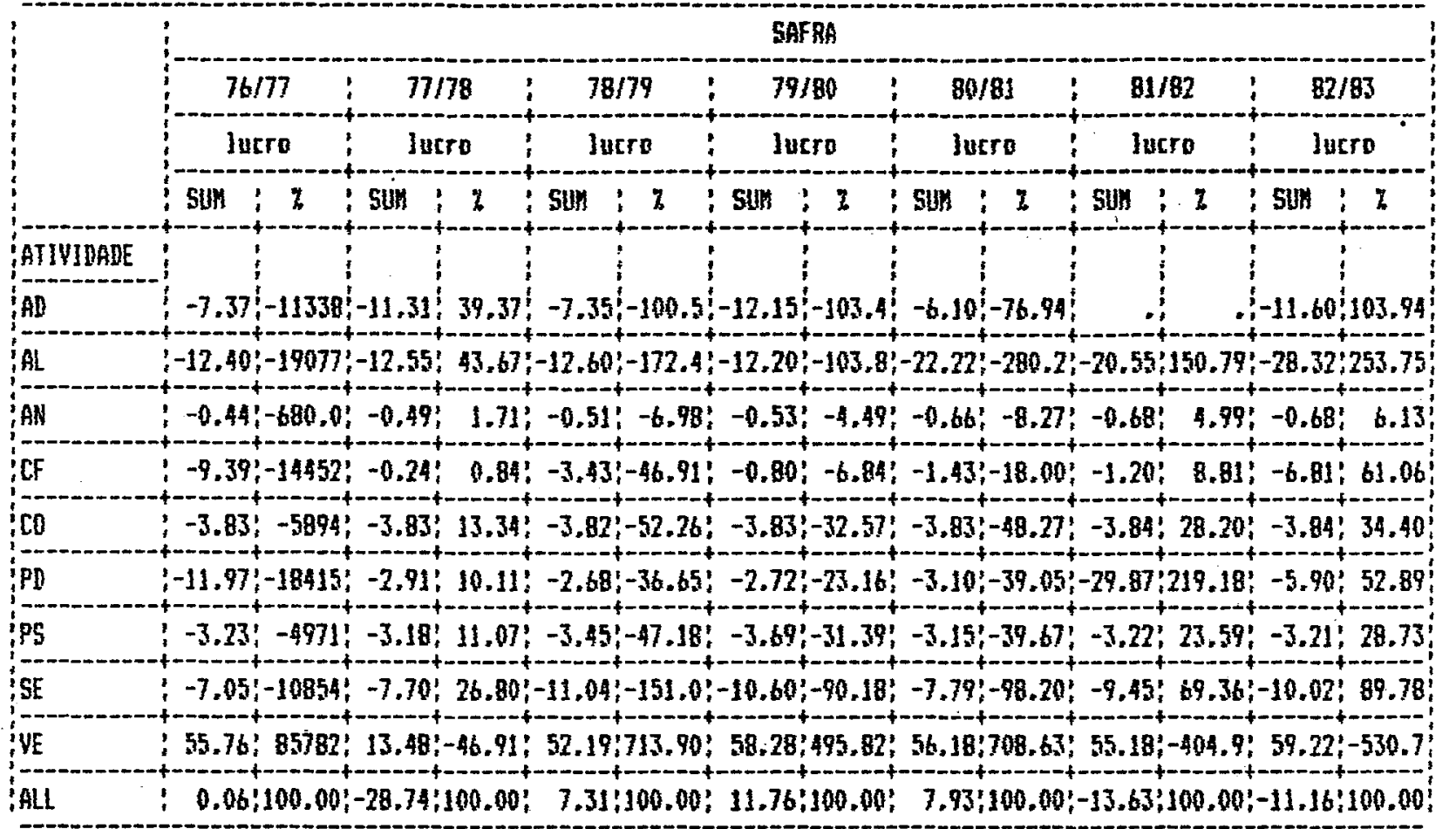

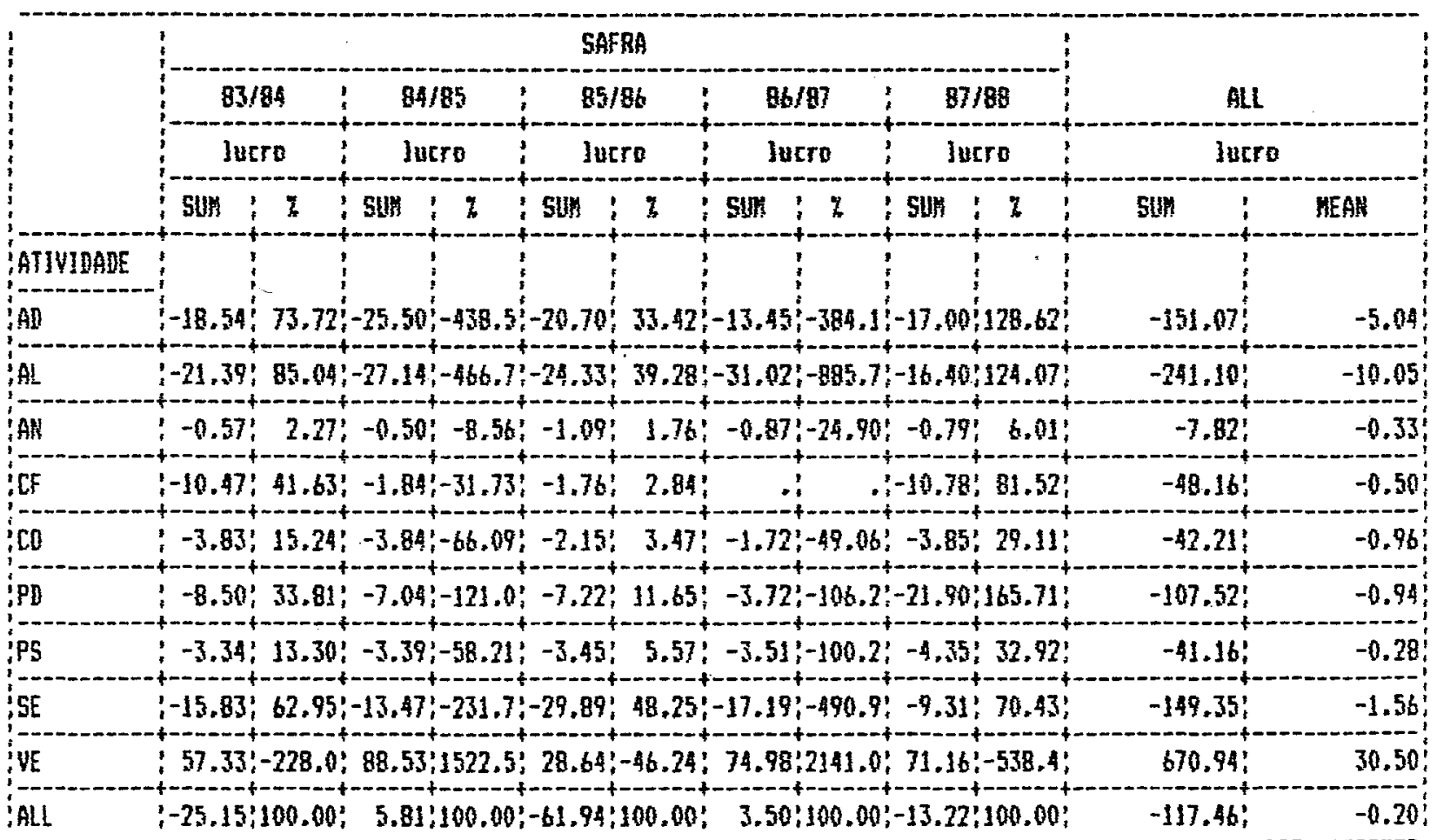


Apendice 5 - Gastos nas operaçz̃es, por rotação, em plantio direto e convencional.

Sistea de plantio $C$ e rotacao $B$

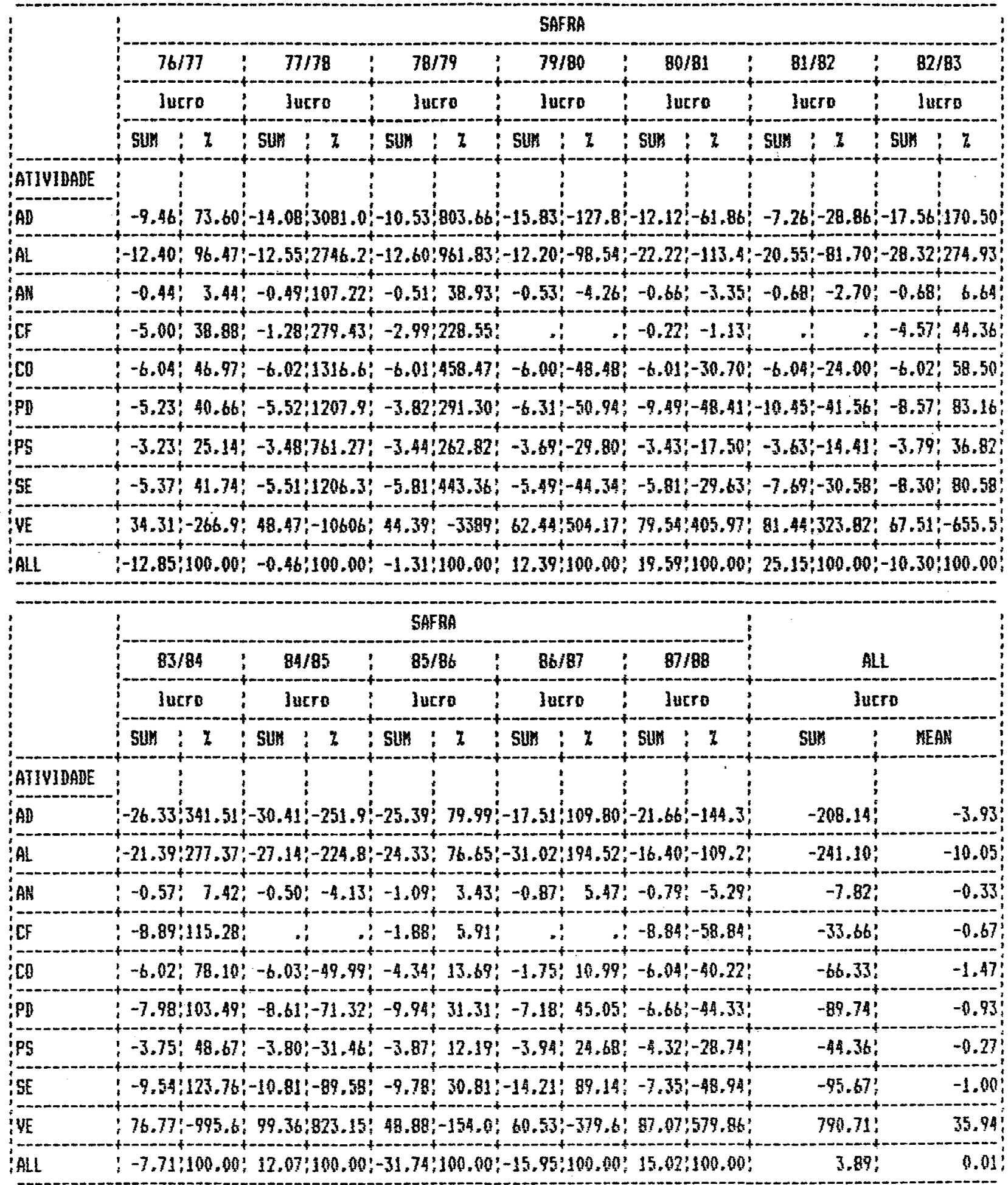


Apendice 5 - Gastos nas operaçช̋es, por rotação, em plantio direto e convencional.

Sistema de puntio C e rotacao D

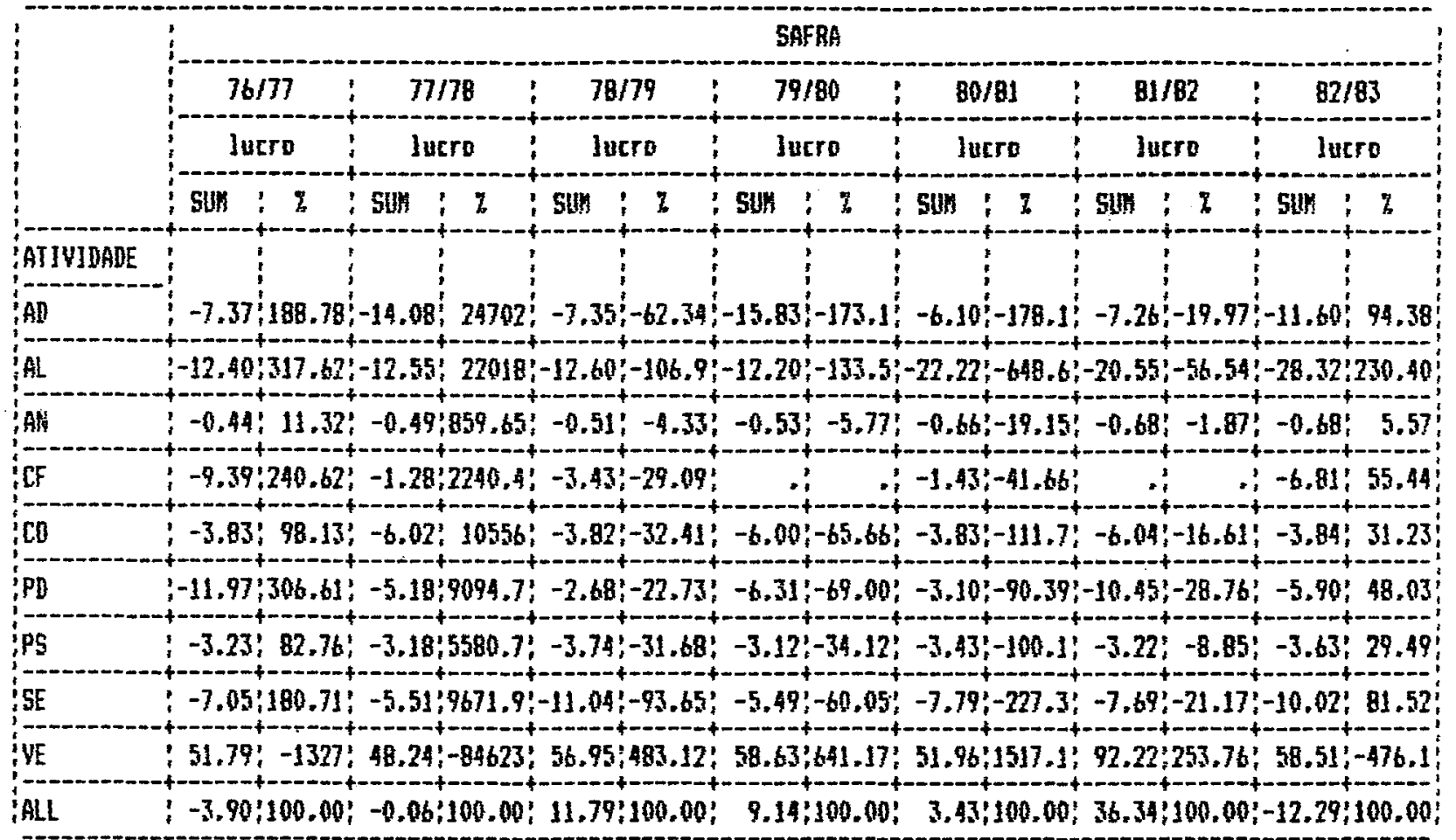

\begin{tabular}{|c|c|c|c|}
\hline \multicolumn{2}{|c|}{ SAFBA } & \multirow[b]{2}{*}{ ALL } & \\
\hline & $85 / 86$ & & \\
\hline & lucro & Juer & \\
\hline & 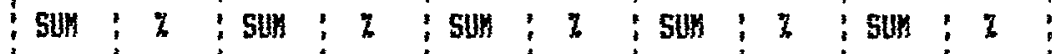 & SIIH & MEAN \\
\hline & 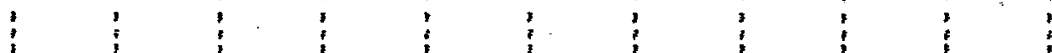 & & \\
\hline 11 & 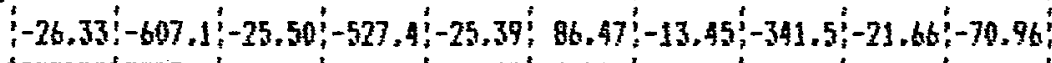 & $-181.92 i$ & $-4.33 !$ \\
\hline ; Al & $:-21.39 ;-493.0 ;-27.14 ;-561,2 ;-24.33 ; 82.86 ;-31,02 ;-787,4 ;-16.40 ;-53,11 ?$ & $-241.10 !$ & -10.05 \\
\hline AN & $:-0.57 ;-13.19 ;-0.50 ;-10.30 ;-1.09 ; \quad 3.71 ;-0.87 ;-27.14 ;-0.79 ;-2.60 ;$ & $-7.82 ;$ & $-0.33 !$ \\
\hline CF & ; $-8.89 ;-204.9:-1.89 ;-38.16 ;-1.75 ; \quad 5.97 ;$ & -43.66 & $-0.57 i$ \\
\hline 60 & ; $-6.02:-138.8:-3.84 ;-79.48 ;-4.35: 14.79:-1.72:-43.62 ;-6.04:-19.78 ;$ & $-55.34:$ & $-1.26 i$ \\
\hline iPD & :-7.98:-184.0:-7.04:-145.6:-9.94: 33.85:-3.72;-94.44:-6.66:-21.80; & $-80.93 ;$ & $-0.79 i$ \\
\hline ips & : $-3.34:-77.09:-3.90 ;-78.53:-3.45: 11.75 ;-3.94:-99.90:-4.30 ;-14.08 ;$ & -42.36 & $-0.27 i$ \\
\hline :SE & $?-9.54:-220.0 ;-13.47:-278.7 ;-9.78: 33.30:-17.19 !-436.5 ;-7.35:-24.07 ?$ & $-111.93 !$ & -1.17 \\
\hline ive & $89.41 ; 2038.0 ; 87.97 ; 1819.4 ; 50.71 ;-172.7 ; 75.84 ; 1925,4 ; 102.57: 335.93$ & B23.80? & $37.45 ?$ \\
\hline 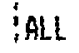 & $4.34 ; 100.00: 4.83 ; 100.00 ;-79.36 ; 100.00: 3.94: 100.00: 30.53 ; 100.00:$ & 58.73; & 0.1 \\
\hline
\end{tabular}


Apêndice 5 - Gastos nas operaçôes, por rotação, em plantio direto e convencional.

Sisten de plantio e rolaca A

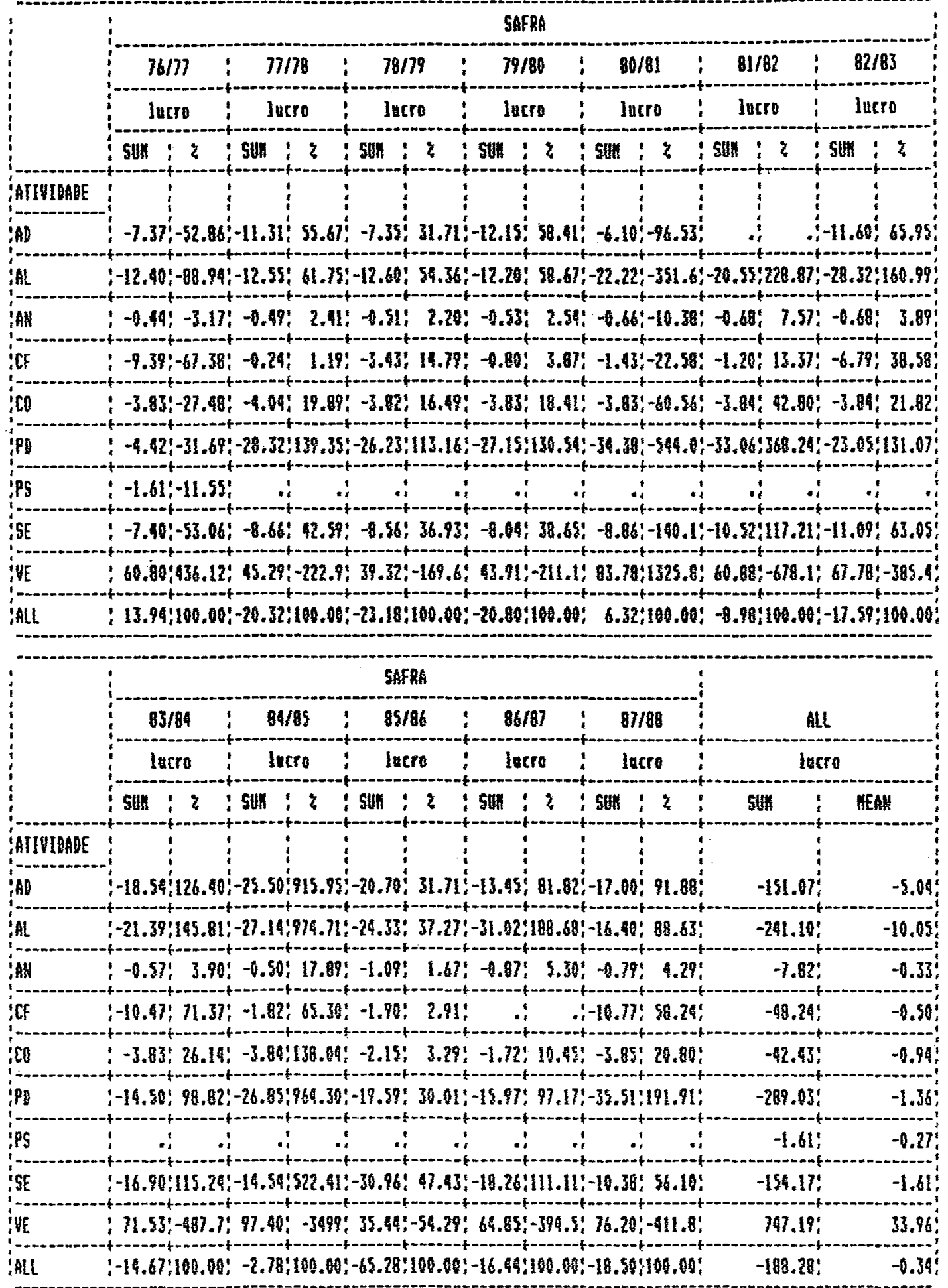


Apéndice 5 - Gastos nas operaçôes, por rotação, em plantio direto e convencional.

Sisten de plantio e rotatao

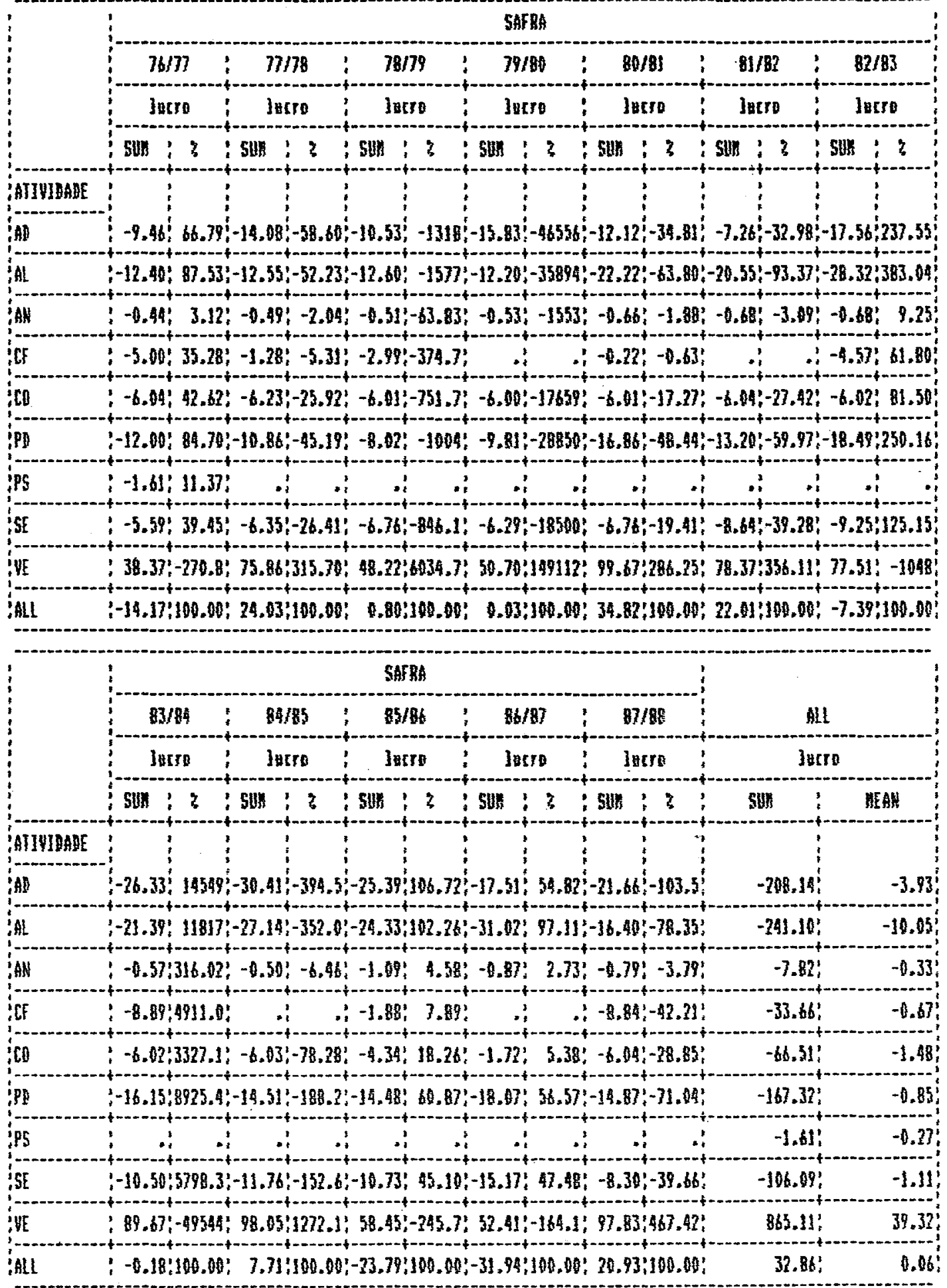


Apéndice 5 - Gastos nas operaçóes, por rotaçăo, em plantio direto e convencional.

Sistena de olantio D e rotarao

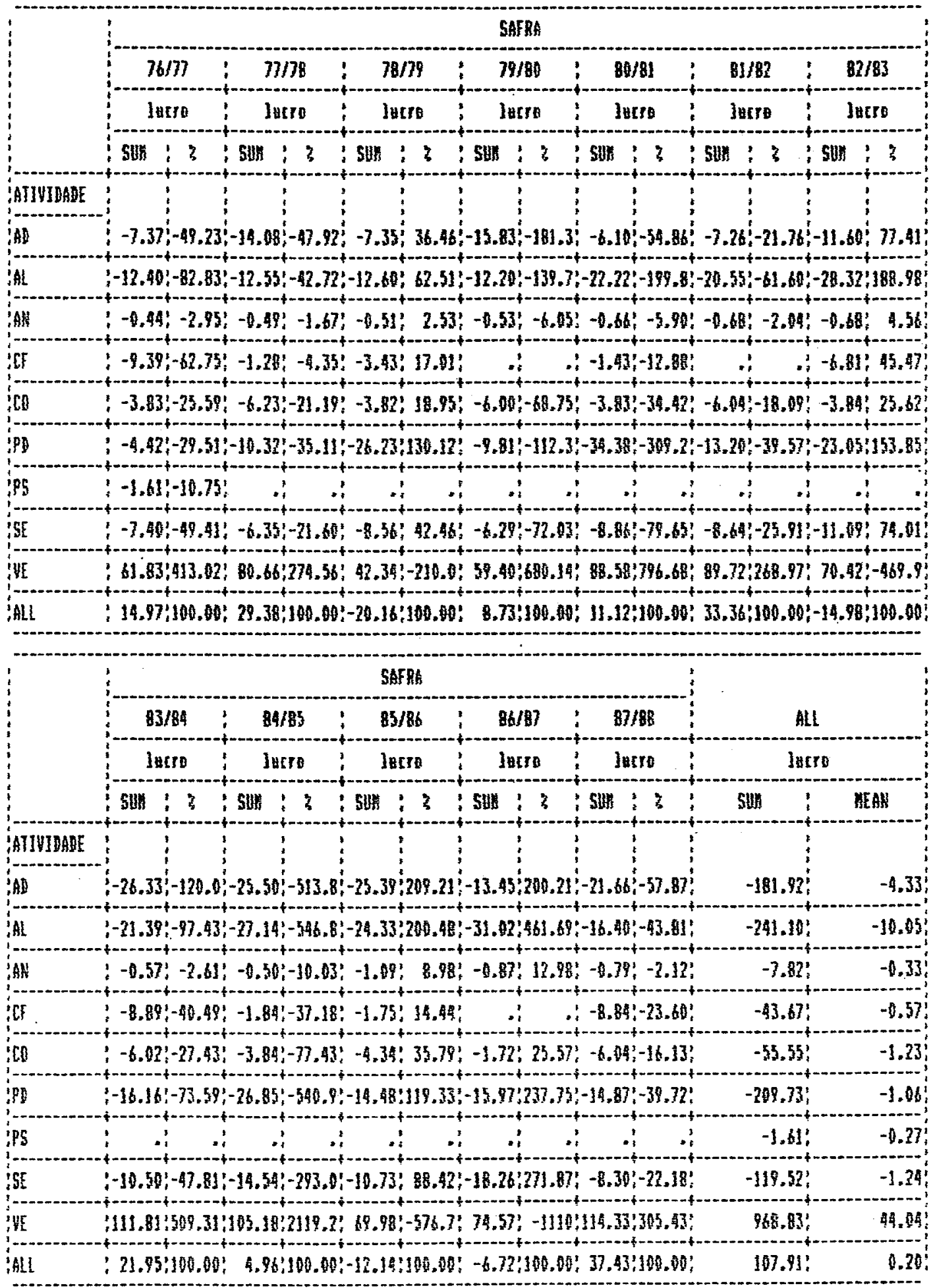


Apéndice $E$ - Diferenģa percentual de gastos e ganho percentual (Pd-PC), por atividade e rotação. entre os sistemas de plantio - 1976,1977 a $1987 / 1988$.

At j vidade

Ganho

Rotaç. CF CO PD PS SE Total(1) VEC 2$)(2)-(1)$

\begin{tabular}{lllllllll}
\hline A & 0,17 & 0,57 & 168,82 & $-96,09$ & 3,23 & 18,65 & 11,37 & $-7,28$ \\
\hline E & --1 & 0,32 & 85,52 & $-96,37$ & 10,94 & 5,72 & 9,41 & 3,59 \\
\hline D & 0,02 & 0,38 & 159,15 & $-96,20$ & 6,78 & 12,53 & 17,61 & 5,05
\end{tabular}

Fonte: Dados da pesquisa.

Apêndice 7 - Diferença de gastos em OTN/ha e ganho, por atividade e rotação, entre os sistemas (Pd-PC). $1976 / 1977$ a $1987 / 1988$.

Ati vidade

Ganho

Rotac. CF CO PD PS SE Total VE(1) (2)-(1)

\begin{tabular}{llllllllll}
\hline A & 0,08 & 0,22 & 181,51 & $-39,55$ & 4,82 & 147,08 & 76,25 & $-70,83$ \\
\hline E & -1 & 0,21 & 77,15 & $-42,75$ & 10,46 & 45,05 & 74,40 & 29,35 \\
\hline D & 0,01 & 0,21 & 128,80 & $-40,75$ & 7,59 & 95,86 & 145,03 & 49,17
\end{tabular}

Fonte: Lados da pesquise.

$C F$ - controle fitossanitario

S - soja $x$ trigo

co - colbeita

E - milho $x$ trigo

PD - controle de ervas

$D \quad-$ soja $\times$ trigo $\times$ milho

PS - preparo do 5010

Pd - plantio direto

$S E$ - plantio

Fo - plantio corvemeioral 